\title{
Spatial population dynamics of brook trout (Salvelinus fontinalis) in a central Appalachian watershed
}

Peter John Lamothe

Follow this and additional works at: https://researchrepository.wvu.edu/etd

\section{Recommended Citation}

Lamothe, Peter John, "Spatial population dynamics of brook trout (Salvelinus fontinalis) in a central Appalachian watershed" (2002). Graduate Theses, Dissertations, and Problem Reports. 1538.

https://researchrepository.wvu.edu/etd/1538

This Thesis is protected by copyright and/or related rights. It has been brought to you by the The Research Repository @ WVU with permission from the rights-holder(s). You are free to use this Thesis in any way that is permitted by the copyright and related rights legislation that applies to your use. For other uses you must obtain permission from the rights-holder(s) directly, unless additional rights are indicated by a Creative Commons license in the record and/ or on the work itself. This Thesis has been accepted for inclusion in WVU Graduate Theses, Dissertations, and Problem Reports collection by an authorized administrator of The Research Repository @ WVU. For more information, please contact researchrepository@mail.wvu.edu. 


\title{
Spatial population dynamics of brook trout (Salvelinus fontinalis) in a central
}

\section{Appalachian watershed}

\section{By}

\author{
Peter John Lamothe
}

\author{
A Thesis \\ Submitted to \\ The College of Agriculture, Forestry, and Consumer Sciences \\ at \\ West Virginia University \\ in partial fulfillment of the requirements \\ for the degree of \\ Master of Science \\ In \\ Wildlife and Fisheries Resources
Patricia M. Mazik, Ph.D., Co-Chair
J. Todd Petty, Ph.D., Co-Chair
Janet Clayton, M.S. \\ Wildlife and Fisheries Program of the Division of Forestry \\ Morgantown, West Virginia \\ 2002
}

Keywords: Acid Precipitation, Brook Trout, Habitat Selection, Population Dynamics, Spawning 


\section{$\underline{\text { Abstract }}$ \\ Spatial population dynamics of brook trout (Salvelinus fontinalis) in a central Appalachian watershed \\ By}

\section{Peter John Lamothe}

I examined the spatial population dynamics of brook trout (Salvelinus fontinalis) in a central Appalachian watershed. The objectives of my research were: 1) identify factors that influence reproduction; 2) determine if factors that influence reproduction influence the distribution and abundance of juvenile and adults; and 3) to determine if the spatial arrangement of stream habitat influence growth, residency, and population fluctuation rates. I used visual surveys and redd counts to quantify spatial variation in habitat quality and brook trout spawning activity. I conducted a mark-recapture study over four seasons to quantify population parameters. The results of my research show that: 1) spawning occurred most often in the headwaters of Second Fork; 2) spawning intensity is a strong predictor of juvenile and small adult densities; and 3) growth and residency rates of juvenile and large adults was greatest in areas where the availability of spawning, feeding, and refuge habitats was greatest. 


\section{Acknowledgments}

I would like to thank the members of my graduate committee, Janet Clayton, Dr. Patricia M.

Mazik, and Dr. J. Todd Petty for their guidance and review of this project. Thanks goes out also to Jesse Bopp, Jason Freund, Matthew Varner, Dan Nulph, Brock Reggi, and Patrick Ammick for field assistance. To Heather Smith, a special thanks for her support of me in my pursuit of this degree. I also wish to thank Becky Nestor for helping to make my graduate experience more enjoyable and less stressful. Finally, thanks to Tom and Nancy Jones for providing housing during my fall field season. The U.S. Fish \& Wildlife Service, the U.S. Geological Survey, the West Virginia Division of Natural Resources, the West Virginia University Division of Forestry, and the Mountaineer Chapter of Trout Unlimited provided research funding. 


\section{Table of Contents}

Forward

List of Tables

vi

List of Figures

viii

Chapter 1: The relationship between reproductive success and population size structure of brook trout in an acid impacted watershed.

Abstract

Introduction

Methods

Results

Discussion

Tables

Figures

Chapter 2: The influence of spatial arrangement and quality of habitats on residency, growth, and population size structure of brook trout in a third order tributary.

Abstract

Introduction

Methods

Results

Discussion

Tables

Figures 


\section{Forward}

This thesis quantifies the effects of biotic and abiotic factors on the population dynamics of brook trout (Salvelinus fontinalis) in Second Fork, a third order tributary of the upper Shavers Fork. For the purpose of publication, the document is presented in two chapters. Chapter one, "The Relationship between Reproductive Success and Spatial Population Structure of Brook Trout in an Acid Impacted Watershed" and chapter two, "The Influence of Spatial Arrangement and Quality of Habitats on Residency, Growth, Population Size Structure of Brook Trout in a Third Order Tributary". I used the Transactions of the American Fisheries Society guide for authors to direct the formatting of chapters one and two. The appendix includes additional stream habitat and fish community structure data that is not intended for future publication, but may be useful to future research in the upper Shavers Fork. 


\section{$\underline{\text { List of Tables }}$}

\section{Chapter 1.}

Table 1. Summary of sampling dates for the study 25

Table 2. Seasonal size classes of brook trout for study period 26

Table 3. Results of multiple regression analysis between spawning locations 27 and stream habitat parameters

Table 4. Results of fish community sampling in Second Fork study sites 28

Table 5. Seasonal brook trout capture data for study sites within the Second 33 Fork watershed

Table 6. Summary of stream $\mathrm{pH}$ measurements taken within the Second Fork watershed

Table 7. Summary of baseflow stream ph levels measured within the eleven study sites

Table 8. Summary of baseflow mean stream alkalinity levels measured within the eleven study sites

Table 9. Summary of continuous stream $\mathrm{pH}$ values recorded during early spring in two headwater sites

Table 10. Results of micro-habitat parameters for all study sites

Table 11. Results of linear regression of spawning intensity and brook trout size class density

Table 12. Results of step-wise multiple linear-regression analysis between large adult density and stream habitat parameters

Table 13. Results of linear regression analysis between seasonal size class density

\section{Chapter 2.}

Table 1. Stream habitat parameters used to rank suitability of study sites for brook trout populations within the Second Fork watershed

Table 2. Physical description of study sites within the Second Fork watershed 
Table 3. Habitat suitability rankings of eleven study sites within the Second Fork watershed for three size class of brook trout

Table 4. Annual growth rates among three size classes of brook trout within the Second Fork watershed

Table 5. Mean seasonal growth rates of brook trout within the Second Fork watershed

Table 6. Mean growth rates among sites based on habitat suitability

Table 7. Results of ranked correlations between brook trout demographic and stream habitat parameters within study sites

Table 8. Variation in residency rates among three size classes of brook trout within the Second Fork watershed

Table 9. Results of analysis of variance for mean residency rates among sites based on habitat suitability

Table 10. Comparison of residency rates among three size classes of brook trout for three levels of habitat suitability within the Second Fork watershed

Table 11. Population size structure and average relative fluctuation (A.R.F) of brook trout within the Second Fork watershed

\section{Appendix.}

\section{Additional fish population data}

Table A1. Seasonal variation of large adult brook trout density within the Second Fork watershed

Table A2. Seasonal variation of juvenile brook trout density within the Second Fork watershed

Table A3. Seasonal variation of small adult brook trout density within the Second Fork watershed

Table A4. Fish community sampling results for the upper Shavers Fork watershed during 2000

Table A5. Brook trout instantaneous growth rates within the Second Fork watershed 
Table A6. Summary of juvenile brook trout mark-recapture results 97

Table A7. Summary of small adult brook trout mark-recapture results 98

Table A8. Summary of large adult brook trout mark-recapture results 99

\section{Additional stream habitat data}

Table A9. Location descriptions for sampling sites within the Second Fork 100 watershed

Table A10. Stream channel unit delineation for the Second Fork watershed 101

Table A11. Stream microhabitat parameters for the Second Fork watershed 105

\section{$\underline{\text { List of Figures }}$}

\section{Chapter 1.}

Figure 1. The upper Shavers Fork watershed of eastern West Virginia 42

Figure 2. Spatial variation in the bedrock geology within the upper 43 Shavers Fork watershed

Figure 3. The Second Fork watershed, with the locations of the eleven sampling sites

Figure 4. Seasonal length frequency histograms from pooled data within the Second Fork watershed

Figure 5. The results of the brook trout spawning activity surveys for Fall 200046

Figure 6. The relationship between the cumulative frequency of redds and stream segments along the continuum of watershed basin area within the Second Fork in Fall 2000

Figure 7. Mean brook trout densities, with error bars, within the Second Fork watershed

Figure 8. Results of continuous stream $\mathrm{pH}$ measurements taken during winter/early Spring 2001

Figure 9. Results of linear regression analysis between brook trout spawning intensity (Fall 2000) and juvenile density (Spring 2001) 


\section{Chapter 2.}

Figure 1. The upper Shavers Fork watershed of eastern West Virginia 84

Figure 2. Spatial trends in mean residency rates of large adult, small adult, $\quad 85$ and juvenile brook trout in Second Fork

Figure 3. Spatial variation in brook trout population size structure within the 86 Second Fork watershed for each season

Figure 4. Seasonal variation in the relative abundance of juvenile, small adult, and large adult brook trout within the Second Fork watershed

Figure 5. Spatial and seasonal average relative fluctuation of brook trout 


\section{Chapter 1:}

\section{The relationship between reproductive success and spatial population structure of brook trout in an acid impacted watershed}

Abstract.- I examined the relationship between spawning site selection, reproductive success, and the spatial population structure of brook trout (Salvelinus fontinalis) residing in Second Fork, a third order stream in eastern West Virginia. The primary objectives of this research were: 1) to identify biotic and abiotic factors that influence brook trout reproduction; and 2) to determine if factors that influence reproduction effectively set the spatial distribution and abundance of juvenile and adult brook trout. I used visual surveys and redd counts to quantify spatial variation in brook trout spawning activity throughout the Second Fork watershed. Electrofishing techniques were used to quantify trout population density and size structure within each of eleven $100 \mathrm{~m}$ study sites distributed throughout the watershed. My analysis produced the following results. 1) Spawning by brook trout was concentrated in small basin area tributaries (i.e. tributaries draining $\left.<2 \mathrm{~km}^{2}\right)$ with relatively high alakalinity $\left(>10 \mathrm{mg} / \mathrm{L} \mathrm{CaCO}_{3}\right)$ and high amounts of instream cover. 2) Densities of juvenile and small adult brook trout were strongly correlated with spawning intensity. Despite the strong correlation, I also found that several areas within the watershed may act as reproductive traps by attracting spawning adults during low flow periods to areas where intense acidic episodes lead to reproductive failure. 3) In contrast to juveniles and small adults, the distribution of large adult trout in subsequent seasons was not related to spawning intensity. Instead, most of the variation in large adult distributions was explained by seasonally important habitat variables, such as instream cover, stream depth and width, and riparian canopy cover. 4) The spatial stability of juvenile and small adult brook trout was high, whereas large adult distributions tended to vary widely from season to season. Based 
on these results, I conclude that stream size and water chemistry interact to influence brook trout reproductive success within the Second Fork watershed; basin area determines the intensity of spawning activity, and water chemistry ultimately determines the successful recruitment of juveniles into the population. Furthermore, I conclude that juveniles and small adults do not disperse widely from natal areas, and consequently, their distribution within the watershed is largely determined by factors that influence reproduction. Finally, large adults appear to be highly mobile, and consequently, their distribution shifts seasonally in response to shifts in habitat requirements and local habitat suitability.

\section{Introduction}

Brook trout populations within the central and southern Appalachian mountains have suffered a reduction in numbers and range due to a combination of anthropogenic impacts, including physical habitat and water quality degradation (Larson and Moore 1985, Jordahl and Benson 1987, Marschall and Crowder 1996). The upper Shavers Fork, a high elevation (> 1000 m) watershed that flows through Pocahontas and Randolph counties in eastern West Virginia (Figure 1), is representative of this trend. The upper Shavers Fork has a minimum of six major tributaries (i.e. $2^{\text {nd }}$ order or larger) that currently support brook trout populations, but currently at lower levels than existed just half a century ago. These separate salmonid populations, may have at one time been linked by dispersal of individuals, possibly forming one metapopulation (i.e. a population of linked populations). The dispersal of individuals between populations is considered an important mechanism of stability for metapopulations of stream fishes (Schlosser and Angermeier 1995, Dunham and Rieman 1999). The overall decline brook trout populations in the Shavers Fork may be due to the decline of one or more of the populations associated with these 
tributaries. The fact that most brook trout populations in West Virginia and throughout the southern extent of their range have been confined to small headwaters streams (Jordahl and Benson 1987, Marschall and Crowder 1996) may increase the larger scale instability of metapopulations through increased isolation and the reduced numbers of dispersing individuals (Dunham and Rieman 1999). The decline of salmonid metapopulations through the reduction and isolation of local populations has been shown in previous studies (Rieman and McIntyre 1996, Dunham and Rieman 1999) and the value of understanding the spatial population structure of salmonids has become a recent tenet in the conservation of these fish (Rieman and McIntyre 1996, Cooper and Mangel 1999, Dunham and Rieman 1999, Young 1999).

The current size and viability of brook trout populations in the tributaries of the upper Shavers Fork is directly associated with the ability of these streams to buffer the negative impacts of acid precipitation (Clayton et al. 1998). The ability of a stream to neutralize acidic inputs is primarily determined by the bedrock type that it flows through (Sharpe et al. 1987, Welsh and Perry 1997). Mauch Chunk and Pottsville are the two dominate bedrock types in the watershed (Cardwell 1968, Welsh and Perry 1997, Figure 2) and streams associated with these bedrock types tend to have relatively low buffering capacities (i.e. alkalinity $<25 \mathrm{mg} / \mathrm{L} \mathrm{CaCO}_{3}$ ). Of the two types, Mauch Chunk, tends to provide a slightly higher neutralizing capability, due to the presence of a small amount of limestone (Ponce et al. 1979, Welsh and Perry 1997).

The effects of depressed stream $\mathrm{pH}$ from acidic precipitation on salmonid populations have been well studied. Effects include altered selection of spawning sites (Johnson and Webster 1977), reduced survival of embryos and fry (Menendez 1976, Trojnar 1977, Jordahl and Benson 1987, Kwain and Rose 1985, Mount et al. 1988, Fiss and Carline 1993), reductions in growth and survival of adults (Mount et al. 1988) and reduction of foraging site quality through 
reductions in the abundance of macroinvertebrates (Krueger and Waters 1983, Clayton and Menendez 1996). The common theme to these effects is the reduced profitability of seasonally important habitats that may lead to reductions in growth, survival, and recruitment. The proximity and profitability of seasonally important habitats that brook trout must move between to complete the annual life cycle, often referred to as complementary habitats, can be critical in determining the population size and probability of persistence for fish in headwater streams (Schlosser 1995).

The importance of habitat complementation to the local population dynamics of brook trout suggests that biologists and managers interested in maintaining or restoring threatened populations should design studies that investigate and quantify the degree to which one or more of these complementary habitats have been degraded. Through a combination of spawning surveys and large scale $(>1 \mathrm{~km})$, seasonal sampling it is possible to capture the temporal and spatial patterns of brook trout population dynamics and then relate population trends to the quality and abundance of spawning habitat throughout the watershed. The quantification of spawning activity in the form of redd counts has become an important tool used in the conservation of salmonid populations (Beard and Carline 1991; Beland 1996; Rieman and McIntyre 1996) and historically has shown strong predictive powers for determining the stability of size structured populations such as brook trout (Benson 1953; Beard and Carline 1991; Beland 1996).

The specific objectives of this study were to: (1) identify critical spawning areas for wild brook trout and determine the physical and chemical habitat parameters that determine brook trout spawning intensity and reproductive success; (2) determine the relationship between spawning locations and spatial and temporal variation in juvenile and adult abundance; and (3) 
establish to what extent brook trout populations in Second Fork are spatially and seasonally stable.

\section{Methods}

Study area - The study was conducted within Second Fork, a $3^{\text {rd }}$ order tributary of the upper Shavers Fork, located in the central Appalachian Mountains of eastern West Virginia (Figure 3). The Second Fork watershed is part of the Monongahela National Forest and is comprised of a mixed deciduous-coniferous forest. Second Fork drains an area of approximately $15 \mathrm{~km}^{2}$ and flows $6.5 \mathrm{~km}$ from its headwaters at Bald Knob $(1475 \mathrm{~m})$ to the confluence with the Shavers Fork (1174 m). Two tributaries of Second Fork, Odey Run ( $2^{\text {nd }}$ order $)$ and Shaft Run ( $2^{\text {nd }}$ order $)$, play an important role in brook trout demography due to their relatively superior water chemistry. The average stream width within the Second Fork varies from $2 \mathrm{~m}$ in the headwater tributaries to $10 \mathrm{~m}$ near the Shavers Fork confluence. Dominant substrates within the mainstem of Second Fork are comprised of boulders and cobble, in addition to occasional patches of gravel, whereas substrate types of cobble and gravel dominate the tributaries.

The headwaters of Second Fork and Odey Run are considered to be acidic with measurements of stream $\mathrm{pH}$ in this area often being less than 5.0. The headwaters of Second Fork are believed to be acidic due to the stream flowing through bedrock with low acid neutralizing capacity coupled with heavy acidic inputs from precipitation. Several smaller tributaries that drain into Second Fork further downstream add appreciable alkalinity and consequently, stream $\mathrm{pH}$ in these lower reaches remains relatively high $(>5.0)$ during acidic episodes. The headwaters of Odey Run flow from a large spruce bog with an associated beaver pond. Downstream of this bog is rich with tannins and stream $\mathrm{pH}$ can be reduced below 4.5 during episodic events. The water chemistry of Odey Run is improved downstream of its 
confluence with L.Odey Run due to this streams relatively high alkalinity levels. Consequently, significant spatial and temporal variation in water quality and landscape attributes within the watershed likely create a high degree of variability in brook trout habitat quality.

Redd counts - I conducted a survey of brook trout spawning activity in the Second Fork watershed during Fall 2000 (Table 1). The stream was walked in both an upstream and downstream direction searching for brook trout engaged in spawning activity. Two different routes were used for the survey in order to avoid spatial and temporal bias in identifying important spawning locations. The first route began in the headwaters of upper Odey Run and continued downstream to the confluence of Odey Run and Second Fork. The route continued upstream along Second Fork to its headwaters. The second route began at the headwaters of Little Odey and continued downstream to the confluence of Little Odey and Odey Run. The route passed over to the upper reaches of Shaft Run and continued downstream along Shaft and Second Fork to the confluence of the Shavers Fork and Second Fork. The section of Second Fork between the mouths of Shaft and Odey Run were surveyed on the way back out of the watershed. The survey routes were alternated between days and surveys were conducted on 30 days between the period of October 5, 2000 and November 24, 2000.

When spawning activity was observed the location was mapped using a combination of GPS and topographical maps and the following parameters were measured: 1) visual estimates of number and total length of individuals engaged in spawning activity, 2) the channel unit type (Petty et al. 2002) the individuals were located in, 3) the substrate type, 4) the water depth and wetted width, and 5) stream $\mathrm{pH}$ and temperature.

The following behavioral criteria were used to determine if brook trout were engaged in spawning activity: 1) individuals actively engaged in the deposition of eggs into the substrate, 
and 2) individuals holding in areas with evidence of recent depositional activity. The small size of spawning individuals resulted in redds that were small in size and evidence of egg deposition quickly disappeared (personal observation). The inability to identify redds once spawning individuals moved to other areas resulted in the conservative criteria that I used during the survey, and is consistent with previous studies conducting salmonid spawning surveys (Magee et al. 1996). Spawning intensity was quantified as the number of redds in a stream reach divided by the area of the stream reach (i.e. redd density).

Stream fish population sampling. - Eleven 100 m survey sites were established in Spring 2000 (Figure 3). Stream fish populations inhabiting these sites were sampled seasonally beginning in Spring 2000 and ending Spring 2001, resulting in four total sampling events for each site (Table 1). A three-pass electrofishing procedure (Thompson and Rahel 1996) was used to estimate a variety of stream fish population parameters, including: species composition, population size, brook trout population size structure, brook trout residency rates, and brook trout growth rates. Prior to population sampling, the ends of each site were blocked with a fine mesh seine $(0.5 \times 0.5$ $\mathrm{mm})$. Two to five person teams, depending on stream size, captured brook trout using backpack electrofishing units (Smith-Root, DC, 60hz, 400-600 V) and a combination of dip and seine nets. A seine net was positioned directly downstream of the individual operating the backpack electrofishing unit in order to capture small fishes. This approach significantly improves the ability to capture fish in high gradient streams dominated by coarse substrate.

In Spring, Summer, and Fall 2000, I processed all fish captured. I focused only on brook trout in Spring 2001, due to time constraints. Individuals captured during sampling were identified to species, anesthetized in clove oil $\left(40 \mathrm{mg} / \mathrm{L} \mathrm{H}_{2} \mathrm{O}\right)$ and measured for standard length $( \pm 1 \mathrm{~mm})$ and weight $( \pm 0.1 \mathrm{~g})$. All fish were returned to their approximate location of capture 
after recovering from the anesthetic. Brook trout were separated into three size classes for each season (Table 2) based on length-frequency distributions of data pooled from the eleven study sites (Figure 4). Following the guidelines of Riley and Fausch (1992), trout densities were calculated as the number of individuals captured within each size class during divided by the area of the study site. Removal estimates of population size were not calculated due to the low numbers (<30 fish) captured within each site (Riley and Fausch 1992).

Water quality analysis - I deployed Hydrolab continuous $\mathrm{pH}$ and temperature loggers to determine stream $\mathrm{pH}$ and its effect on brook trout embryo survival in two locations (Sites 9 and 10) known to be potentially important to brook trout spawning. Meters were programmed to record stream pH at intervals of two hours from February 10, 2001 to April 7, 2001, a period of time when acidic episodes were likely to occur and brook trout eggs and larvae were most susceptible (Jordahl and Benson 1987, Fiss and Carline 1993). Stream alkalinity and pH was determined from filtered water samples (filter size $0.45 \mu \mathrm{m}$ ) taken within each study site when the stream was at approximately baseflow (Table 1). Samples were immediately placed on ice and were processed within forty-eight hours of collection. Samples were analyzed according to the American Public Health Association (APHA 1989) for total alkalinity (potentiometric titration to $\mathrm{pH} 4.5)$.

Habitat surveys - A modified basinwide visual estimation technique (BVET) (Dolloff et al. 1997) was used to quantify continuous variation in

salmonid habitat parameters (Table 1). Working in an upstream direction, habitat and channel morphology measurements were taken at $50 \mathrm{~m}$ intervals throughout the watershed. The spacing between transects was maintained using a $50 \mathrm{~m}$ measuring tape. At each transect, channel width, canopy cover, average depth, dominate substrate, percent cover (instream and 
bank), percent of area as stream margin, and percent of area suitable for brook trout spawning were visually estimated. Stream wetted width at the transects and maximum depth within each $50 \mathrm{~m}$ section were measured using a graduated section of polyvinyl chloride (pvc) pipe $( \pm 0.5$ $\mathrm{m})$. Within each $50 \mathrm{~m}$ section the length of each channel unit was measured from the measuring tape and the width was visually estimated. Channel units were identified as homogenous (e.g. riffle, glide, pool) or complex (e.g. riffle-run, riffle-glide) and labeled accordingly (Bisson et al. 1982, Petty et al. 2002).

Statistical analysis - A variety of statistical tests were employed to address the objectives of the study. I used a Kolmogrov-Smirnov test to assess the goodness of fit of the observed cumulative frequency of brook trout redds with the expected cumulative frequency of stream reaches available for spawning along the continuum of basin area throughout the watershed. This test should show whether or not brook trout were spawning disproportionately in specific areas of the watershed.

Stepwise multiple regression was used to determine which variables brook trout were selecting for in choosing a spawning site. Variables that have been shown to be important to brook trout spawning site selection (Witzel and MacCrimmon 1983) and brook trout juvenile habitat suitability (McLaughlin et al. 1994) were selected for the model and include stream width, basin area, the availability of cover, stream $\mathrm{pH}$ and alkalinity. A two sample t-test of means of micro-habitat variables between the main channel of Second Fork and its tributaries provided additional insight into brook trout spawning site selection by identifying differences in habitat availability between the two areas.

Linear regression analysis with redd density as the independent variable and densities of the three size classes of brook trout (i.e. juvenile, small adult, and large adult) in our populations 
as the dependent variable was used to (1) determine which areas of the watershed were important for juvenile recruitment; and (2) the seasonal importance of spawning areas to different portions of the brook trout population. This analysis should answer the question of whether or not spawning intensity can predict the temporal and spatial variation in juvenile and adult brook trout abundance. I also used linear regression to determine the seasonal and year-to-year stability of densities for each size class of brook trout in Second Fork. Stability of populations at high densities over time in a stream reach suggests that these areas may have high quality habitat and protection of these areas may be an important component of future management efforts.

\section{Results}

\section{Spatial variation in spawning activity}

Sixty spawning locations were identified (Figure 5), with a majority $(>76 \%$ ) of spawning occurring in the headwater tributaries to Second Fork with basin areas of $2.5 \mathrm{~km}^{2}$ or less. The disproportionate use of the headwaters for spawning is proven statistically by the trend that the cumulative frequency of redds was significantly different from the cumulative frequency of stream reaches in the headwaters of Second Fork (Dmax $=0.263, n=60, p<0.001$, Figure 6). Variables that best predicted brook trout spawning habitat selection include: 1) basin area, 2) stream alkalinity, and 3) amount of available cover (Table 3). The greatest number of redds (22) were located in the headwaters of Little Odey Run. Microhabitat measurements taken at the time and location of spawning showed that brook trout spawned most frequently in the tail section of pools (34 of 60 observations) at an average depth of $0.41 \mathrm{~m}$ (range $0.2-0.7 \mathrm{~m}$ ). Spawning occurred in locations with substrate composed of gravel or mixed gravel with a mean wetted width of $2.54 \mathrm{~m}$. Stream $\mathrm{pH}$ in spawning locations ranged from 5.48 to 7.28 with a mean of 6.36 . 


\section{Stream fish population sampling}

The stream fish community and brook trout populations in particular displayed both spatial and temporal variation during my four sampling seasons. I identified 14 species of stream fish during my sampling of study sites in the Second Fork watershed (Table 4). The diversity of species was greatest in the lower reaches of Second Fork, especially in Site 1, probably due to the proximity to the Shavers Fork. The headwater sites (i.e. Sites 9,10, \& 11) were occupied only by brook trout. Both adult brown trout (Salmo trutta) and rainbow trout (Oncorhynchus mykiss) were captured during my sampling. I did not capture juvenile brown or rainbow trout in Second Fork suggesting that successful reproduction for these species is not occurring in the Second Fork watershed.

I captured 1621 brook trout within the eleven study sites during the four seasons of the study (Table 5). The largest number (288) of brook trout were captured in Site 10 and the smallest number (85) were captured in Site 9 during the study. Juvenile and small adult brook trout were most abundant (160 and 107) in Site 10, while large adult brook trout were most abundant (49) in Site 3.

Mean density of juvenile brook trout (Figure 7) for the study period was highest in Site 10 (1527 individuals/ha) and lowest in Site 5 (119 individuals/ha). Mean density of small adult brook trout (Figure 7) was also highest in Site 10 (1025 individuals/ha), but was lowest in Site 1 (119 individuals/ha). Mean density of large adult brook trout (Figure 7) for the study period was greatest in Site 10 (222 individuals/ ha) and lowest in Site 7 (91 individuals/ha).

\section{Water quality and instream habitat parameters}

I observed substantial variation in stream $\mathrm{pH}$ and alkalinity within the Second Fork watershed (Tables 6-9). The areas of Second Fork above the inlet of Odey Run (sites 7 and 11) 
and the headwaters of Odey Run (site 9) tended to be the most acidic. Stream alkalinities (mg/L $\left.\mathrm{CaCO}_{3}\right)$ were significantly higher within the tributaries than the main channel of Second Fork $(\mathrm{t}$ value $=3.05, \mathrm{df}=20, \mathrm{p}<0.007)$, with the highest measurements being recorded in study site 10 (i.e. Little Odey Run). Perhaps the most striking differences among sites involve minimum $\mathrm{pH}$ (Table 6). The minimum $\mathrm{pH}$ measurements for sites 8 and 9 were recorded during an intense rain event that may have overwhelmed the buffering capacity of the stream in these locations. This acidic event was not recorded in other sites due to a limited number of continuous $\mathrm{pH}$ meters. A summary of stream $\mathrm{pH}$ and alkalinity measurements taken at approximately baseflow within each study site is shown in Tables 7 and 8. The timing and duration of an acidic episode in study sites 9 and 10 are shown in (Table 9) and (Figure 8).

Analysis of microhabitat availability (Table 10) resulted in significant differences between the main channel of Second Fork and its tributaries. The mean availability of undercut banks $(\mathrm{t}$-value $=2.36, \mathrm{df}=21, \mathrm{p}<0.03)$ and suitable spawning habitat $(\mathrm{t}$-value $=2.77, \mathrm{df}=21$, $\mathrm{p}<0.02$ ) were found to be significantly higher within tributary study sites. Average depth (t-value $=2.72, \mathrm{df}=21, \mathrm{p}<0.02)$ and the mean availability of instream cover $(\mathrm{t}$-value $=3.06, \mathrm{df}=21$, $\mathrm{p}<0.01)$ were significantly higher in the main channel sites. No significant differences in means of maximum depth, \% stream margin, \% cover, and \% canopy cover were observed.

\section{Relationship between spawning activity and size-class densities}

I observed a significant linear relationship between spawning intensity in Fall 2000 and juvenile density in Spring 2001 (Table 11, Figure 9). A similar relationship was found between spawning intensity and young adult density in Spring 2001 (Table 11). Significant linear relationships between spawning intensity in Fall 2000 and juvenile and young adult densities in the spring, summer, and fall samplings of 2000 also were observed (Table 11). These findings 
indicate a strong control of brook trout reproduction on the distribution and abundance of early life stages in the system. In contrast, I did not observe a significant relationship between spawning intensity and large adult density in any season (Table 11), indicating that factors other than spawning act to control the distribution and abundance of older trout. Relationship between stream habitat variables and large adult density Habitat variables, unlike spawning intensity, provided a consistent explanation for the distribution of large adult brook trout in the watershed (Table 12). In Spring 2000, large adult brook trout density was highest in areas with increasing amounts of instream cover and relatively narrow stream widths. Large adult density in summer was highest in areas with narrow stream widths, open canopy, and increasing average stream width. In Fall 2000, large adult density was highest in areas with increasing amounts of suitable spawning habitat, and decreasing amounts of stream margin. Large adult density in Spring 2001 was highest in areas with increasing amounts of undercut banks.

Seasonal stability of size class densities

My analysis showed that the spatial distributions of juvenile and small adult brook trout densities were temporally stable within study sites with high density sites tending to remain high and low density sites tending to remain low (Table 13). The results of this analysis mirror those showing the relationship between these size classes and spawning activity, suggesting that the distribution of early life stages is effectively set by factors influencing spawning and reproductive processes. Large adult brook trout populations were not stable with significant seasonal and spatial shifts in densities. In contrast, I found that the ability to predict future trends in numbers of large adults based on current or past numbers was extremely low (Table 13). 


\section{Discussion}

Spatial variation in spawning intensity and reproductive success

Stream size was clearly the most important factor influencing where brook trout focus their reproductive efforts in the Second Fork watershed. Nearly $80 \%$ of all spawning observed in the watershed occurred in tributaries with a basin area less than $3 \mathrm{~km}^{2}$. Ultimate reproductive success, however, was controlled by water chemistry, not stream size. This conclusion is based on an examination of the relationship between juvenile density in Spring 2001 (i.e., reproductive success), spawning intensity in Fall 2000 (i.e., reproductive effort), and alkalinity (Figure 9). Clearly, reproductive success depends on reproductive effort, which is itself dependent on stream size. However, regardless of effort, successful reproduction was observed only in streams where alkalinity exceeded 5-10 mg/L CaCO${ }^{3}$ ) (Figure 9). Despite relatively high reproductive effort in Fall 2000, two areas located in the headwaters of Second Fork experienced complete reproductive failure in Spring 2001 (Figure 9).

The relationship between spawning activity and juvenile density the following spring also provides evidence for the existence of reproductive traps in Second Fork. The brook trout spawning season of fall 2000 was very dry and stream levels were approximately at baseflow. This low flow condition allowed stream $\mathrm{pH}$ levels to rise above 5.5, even in sites with alkalinities below $5 \mathrm{mg} / \mathrm{L} \mathrm{CaCO}_{3}$. Johnson and Webster (1977) found that brook trout would avoid spawning sites with $\mathrm{pH}$ levels below 5.0. Above this level brook trout would not discriminate between spawning locations based on $\mathrm{pH}$. This behavior may allow brook trout in Second Fork to spawn in areas that act as reproductive traps. The suitable conditions that occur during baseflow may allow brook trout to deposit eggs into stream sections with low buffering capacity and little chance of survival. The next rain event that overwhelms the buffering capacity of these 
locations will drive stream $\mathrm{pH}$ levels lower and may cause complete or partial mortality to the eggs.

The reduced survival of brook trout eggs and larvae at low $\mathrm{pH}$ levels has been well documented in the literature (Menendez 1976, Kwain and Rose 1985). The critical determinant of survival for wild brook trout fry possibly is the timing and duration of acidic episodes. If adults deposit eggs in areas with groundwater upwellings, the ambient $\mathrm{pH}$ levels may protect eggs during development from minor reductions in stream $\mathrm{pH}$ levels. Juveniles emerging from the protection of the redd during an episodic event would be likely to perish due to the sudden change from a relatively high $\mathrm{pH}$ levels in the redd to the acidic conditions of the stream (Jordahl and Benson 1987, Fiss and Carline 1993). The extent to which acidic episodes cause mortality of brook trout juveniles is also partly determined by the duration of the event. Bioassays of brook trout in acidic streams show that individuals can survive acidic episodes that last less than 24 hours (Menendez et al. 1996). The acidic episode in Upper Odey Run during the middle of February 2000 caused stream pH levels to drop below 4.5 for over 70 hours. I believe that it was this acidic event that caused the reproductive failure observed in Spring 2001.

\section{Variation in brook trout densities and fish community structure}

The high densities of brook trout, especially juveniles and small adults, in the tributaries of Second Fork show the importance of these areas to the overall population. Site 10 had the highest densities of brook trout for all three size classes. Densities of juvenile and small adult brook trout in Site 11 were relatively low with very little variation, when compared to the other headwater sites, possibly due the acidic conditions in this area of the watershed. Densities of juvenile and small adult brook trout in Site 9, which is also acidic, were generally higher than Site 11. This trend suggests that while minimum $\mathrm{pH}$ levels in both sites drop below critical levels 
reproductive depression or failure occurs more consistently in the headwaters of Second Fork possibly from different flow regimes that extend the duration of acidic events (Menendez et al. 1996) in this area or from a combination of reduced $\mathrm{pH}$ levels and toxicity from heavy metals (Mount et al. 1988).

The community structure of stream fishes in the Second Fork watershed may be influencing the spatial variation in the abundance and size structure of brook trout. The high diversity of fishes in the lower reaches of Second Fork may provide increased foraging opportunities for individuals large enough to be piscivores. This same diversity may act to regulate the numbers of juveniles through predation, possibly from introduced salmonids or through cannibalism.

Spatial variation in water quality and its importance to Second Fork brook trout populations

Surprisingly, I found that tributaries flowing only a few meters apart in the headwaters of Second Fork have differences in water chemistry, brook trout population densities, and recruitment. I also observed significant changes in stream $\mathrm{pH}$ and alkalinity within relatively short $(<300 \mathrm{~m})$ sections of the same stream sections. The section of Second Fork above the mouth of Odey Run (Sites 7 and 11) would be too acidic for brook trout if not for the input of alkalinity from smaller ephemeral tributaries in its headwaters. This spatial variation in water quality has had a negative impact on brook trout populations in this watershed due to an extreme reliance on two relatively small tributaries for recruitment of juveniles. Clearly, degradation of habitat within these small tributaries would have a severe impact on the overall brook trout populations within Second Fork. While the reproductive ramifications have already been discussed it is also important to note that the relatively high alkalinity outputs from the smaller tributaries into the main channel of Second Fork may have positive impacts on the foraging and 
refuge habitat quality downstream of these tributaries (Bopp 2002). It is my opinion that any restoration plan for salmonid fishes in the upper Shavers Fork should prioritize the identification and protection of these small, high alkalinity tributaries. If the population dynamics of brook trout in Second Fork are similar to those of the other tributaries of the upper Shavers, a small number of suitable spawning areas may be responsible for maintaining the population at its current level.

Spawning activity as a predictor of population size structure

Brook trout spawning activity within the Second Fork drainage proved to be a strong predictor of juvenile and small adult densities within my study sites. The strong correlations between spawning activity and both juveniles and young adult densities for each season of the study suggests that individuals within these size-classes do not disperse long distances from spawning locations. This idea of size dependent dispersal is further supported by strong seasonal stability of juvenile and small adult brook trout throughout the watershed. These results add to the value of the tributaries since they may be important nursery areas for brook trout in their first and second year of life. Also, these results are consistent with the results of similar studies with brown trout (Salmo trutta) and Atlantic salmon (Salmo salar) (Beard and Carline 1991, Beland 1996). Contrary to the findings of this study, Beard and Carline (1991) also found a significant relationship between spawning locations and large adult densities. The simple regression model of spawning intensity as a predictor of juvenile abundance the following spring (Figure 9) also shows that two sites ( 2 and 4 ) had higher than expected juvenile densities. This may be the result of missed spawning activity in that area of the watershed or perhaps, from dispersal of juveniles from upstream spawning locations during high flow events. 


\section{Spatial and temporal variation in large adult densities}

While the habitat suitability of small tributaries in the Second Fork watershed may be high for fish in the first and second years of life, larger individuals were not consistently found in these locations in high densities. The inability of spawning activity within the watershed to predict spatial variation in large adult densities suggests that this size class may be making habitat selection choices based on different criteria than the smaller classes of brook trout. The weak correlation between large adult densities and spawning intensity may also be the result of the high mobility of these larger fish allows for access to habitats throughout the watershed. Seasonal habitat selection patterns may be driven by temporal and spatial variation in foraging site quality in these low productivity streams. As the flow of energy from inputs of organic matter in the fall begin to dissipate in early summer, large individuals may be forced to move to access areas with higher foraging site suitability. Bopp (2002) showed that during late summer, stream reaches with open canopy had a significantly higher abundance of benthic macroinvertebrates than stream reaches with a closed canopy. The increased abundance of macroinvertebrates should result in a relative increase in foraging site quality. This potential difference in forage site quality helps to explain the spatial variation in large adult brook trout densities during my summer sampling.

The fact that the percentage of spawning habitat available in a location was included in the multiple regression models to explain variability in large adults densities during the fall suggests to me that as these fish grow the criteria for spawning site selection is changing. Larger individuals may be selecting spawning sites based on proximity to winter habitat or other unknown criteria. If this is true these larger fish may prefer to spawn in the main channel of Second Fork since deep $(>1 \mathrm{~m})$ pools are more abundant here than in the tributaries. 


\section{Management implications}

The major management implications from this portion of the study deal with the identification and protection of small tributaries, with high alkalinity, for brook trout reproduction and mitigation of the effects of acid precipitation by adding limestone fines to impacted headwater locations. As previously mentioned, low stream alkalinities and the potential for reproductive traps may be limiting brook trout populations throughout the upper Shavers Fork basin (Clayton et al. 1998, and this study). The identification and protection of areas that brook trout are currently spawning in successfully should be a management priority. Once these areas are identified, artificial barriers to these areas, such as improperly installed road culverts, should be removed or redesigned to allow fish passage. Headwater streams that are not suitable for reproduction, due solely to low stream alkalinities, should have limestone fines added to them. The headwaters of Second Fork and Odey Run would seem to be suitable candidates.

The addition of limestone fines to the bed of streams has been shown to be a successful technique in mitigating the effects of acid precipitation in other watersheds (Lacroix 1992, Clayton and Menendez 1996, Menendez et al. 1996, Clayton et al. 1998). Lacroix (1992) found that the addition of crushed limestone to Fifteen Mile Brook, an acidic stream located on the southwest coast of Nova Scotia, Canada, resulted in increased spawning activity of Atlantic salmon and increased abundance of both salmon and brook trout. Clayton and Menendez (1996), Menendez et al. (1996), and Clayton et al. (1998) showed that the addition of limestone fines is an effective, relatively inexpensive method for restoring stream water quality, aquatic invertebrates, and fish community parameters to acidified streams in West Virginia. Historically, limestone additions to tributaries of the Shavers Fork, downstream of Second Fork, have resulted 
in increased numbers of brook trout, and apparent increases in reproductive success due to increases in juvenile brook trout numbers (Clayton et al. 1998).

The combination of increased reproductive success and lowered mortality from the impacts of acidic episodes should lead to an increase in the carrying capacity for trout in Second Fork. The increase in numbers may lead to an increase of emigrants from Second Fork, into the main channel of the Shavers Fork and the associated tributaries, that could be extremely positive as a stabilizing mechanism for both population size and genetic variability. Increased numbers of trout in the mainstem of the Shavers Fork may have the additional benefit of improving the quality of the recreational sport fishery that currently exists. 


\section{References}

APHA (American Public Health Association, American Water Works Association, and Water Pollution Control Federation). 1989. Standard methods for the examination of water and wastewater, $16^{\text {th }}$ edition. APHA, Washington, D.C., USA.

Beard, T.D., and R.F. Carline. 1991. Influence of spawning and other stream habitat features on spatial variability of wild brown trout. Transactions of the American Fisheries Society 120:711722.

Beland, K.F. 1996. The relation between redd counts and Atlantic salmon (Salmo salar) parr populations in the Dennys River, Maine. Canadian Journal of Fisheries and Aquatic Sciences 53:513-519.

Benson, N.G. 1953. The importance of groundwater to trout populations in the Pigeon River, Michigan. Transactions of the North American Wildlife Conference 18:268-281.

Bisson, P.A., J.L. Nielsen, R.A. Palmason, and L.E. Grove. 1982. A system for naming habitat types in small streams, with examples of habitat utilization by salmonids during low streamflow. Proceedings of the symposium on Acquisition and Utilization of Aquatic Habitat Inventory Information. p.62-73.

Bopp, J. 2002. The combined effects of water chemistry, canopy cover, and basin area on benthic macroinvertebrates along a central Appalachian stream continuum. Master's Thesis. West Virginia University.

Cardwell, D.H., R.B. Erwin, H.P. Woodward, and C.W. Lotz. 1968. Geologic map of West Virginia. West Virginia Geological and Economic Survey.

Clayton, J.L., and R. Menendez. 1996. Macroinvertebrate responses to mitigative liming of Dogway Fork, West Virginia. Restoration Ecology 4(3):234-246.

Clayton, J.L., E.S. Dannaway, R. Menendez, H.W. Rauch, J.J. Renton, S.M. Sherlock, and P.E. Zurbuch. 1998. Application of limestone to restore fish communities in acidified streams. North American Journal of Fisheries Management 18:347-360.

Cooper, A.B., and M. Mangel. 1999. The dangers of ignoring metapopulation structure for the conservation of salmonids. Fishery Bulletin 97(2):213-226.

Curry, R.A., D.L.G. Noakes, and G.E. Morgan. 1995. Groundwater and the incubation and emergence of brook trout (Salvelinus fontinalis). Canadian Journal of Fisheries and Aquatic Sciences 52:1741-1749.

Dolloff, A.C., H.E. Jennings, and M.D. Owens. 1997. A comparison of basin-wide and representative reach habitat survey techniques in three southern Appalachian watersheds. North American Journal of Fisheries Management 17(2):339-347. 
Dowdy, S., and S. Wearden. 1991. Statistics for Research. $2^{\text {nd }}$ edition. John Wiley and Sons. N.Y.

Dunham, J.B., and B.E. Rieman. 1999. Metapopulation structure of bull trout: Influences of physical, biotic, and geometrical landscape characteristics. Ecological Applications 9(2):642655.

Dunham, J., B. Rieman, and K. Davis. 2001. Sources and magnitude of sampling error in redd counts for bull trout. North American Journal of Fisheries Management 21:343-352.

Fiss, F.C., and R.F. Carline. 1993. Survival of brook trout embryos in three episodically acidified streams. Transactions of the American Fisheries Society 122:268-278.

Hetrick, N.J., M.A. Brusven, T.C. Bjornn, R.M. Keith, and W.R. Meehan. 1998. Effects of canopy removal on invertebrates and diet of juvenile coho salmon in a small stream in southeast Alaska. Transactions of the American Fisheries Society 127:876-888.

Johnson, D.W., and D.A. Webster. 1977. Avoidance of low pH in selection of spawning sites by brook trout (Salvelinus fontinalis). Journal of Fisheries Research Board of Canada 34:2215-2218.

Jordahl, D.M., and A. Benson. 1987. Effect of low pH on survival of brook trout embryos and yolk-sac larvae in West Virginia streams. Transactions of the American Fisheries Society 116:807-816.

Krueger, C.C., and T.F. Waters. 1983. Annual production of macroinvertebrates in three streams of different water quality. Ecology 64(4):840-850.

Kwain, W., and G.A. Rose. 1985. Growth of brook trout Salvelinus fontinalis subject to sudden reductions of $\mathrm{pH}$ during their early life history. Transactions of the American Fisheries Society 114:564-570.

Lacroix, G.L. 1992. Mitigation of low stream $\mathrm{pH}$ and its effects on salmonids. Environmental Pollution 78:157-164.

Larson, G.L., and S.E. Moore. 1985. Encroachment of exotic rainbow trout into stream populations of native brook trout in the southern Appalachian mountains. Transactions of the American Fisheries Society 114:195-203.

Magee, J.P., T.E. McMahon, and R.F. Thurow. 1996. Spatial variation in spawning habitat of cutthroat trout in a sediment-rich stream basin. Transactions of the American Fisheries Society 125:768-779.

Marschall, E.A., and L.B. Crowder. 1996. Assessing population responses to multiple anthropogenic effects: A case study with brook trout. Ecological Applications 6(1):152-167. 
McLaughlin, R.L., J.W.A. Grant, and D.L. Kramer. 1994. Foraging movements in relation to morphology, water-column use, and diet for recently emerged brook trout (Salvelinus fontinalis) in still-water pools. Canadian Journal of Fisheries and Aquatic Sciences 51:268-279.

Menendez, R. 1976. Chronic effects of reduced pH on brook trout (Salvelinus fontinalis). Journal of Fisheries Research Board of Canada 33:118-123.

Menendez, R., J.L. Clayton, P.E. Zurbuch. 1996. Chemical and fishery responses to mitigative liming of an acidic stream, Dogway Fork, West Virginia. Restoration Ecology 4(3):220-233.

Mount, D.R., C.G. Ingersoll, D.D. Gulley, J.D. Fernandez, T.W. LaPoint, and H.L. Bergman. 1988. Effect of long-term exposure to acid, aluminum, and low calcium on adult brook trout (Salvelinus fontinalis). 1. Survival, growth, fecundity, and progeny survival. Canadian Journal of Fisheries and Aquatic Sciences 45:1623-1632.

Petty, J.T., J. Freund, P.J. Lamothe \& P.M. Mazik. 2001. Quantifying the microhabitat characteristics of hydraulic channel units in the upper Shavers Fork basin. Proceedings of the Southeastern Association of Fish and Wildlife Agencies In Press.

Ponce, S.L., K.D. Sundeen, and W.D. Striffler. 1979. Effect of selected geology-soil complexes on water quality of Little Black Fork Creek. Completion report to the U.S. Forest Service, USDA, Northeastern Forest Experiment Station, Research Work Unit FS-NE-1602.

Rieman, B.E., and J.D. McIntyre. 1996. Spatial and temporal variability in bull trout redd counts. North American Journal of Fisheries Management 16:132-141.

Riley, S.C., and K.D. Fausch. 1992. Underestimation of trout populations size by maximumlikelihood removal estimates in small streams. North American Journal of Fisheries Management 12:768-776.

Schlosser, I.J. 1995. Critical landscape attributes that influence fish population dynamics in headwater streams. Hydrobiologia 303:71-81.

Schlosser, I.J., and P.L. Angermeier. 1995. Spatial variation in demographic processes of lotic fishes: Conceptual models, empirical evidence, and implications for conservation. American Fisheries Society Symposium 17:392-401.

Sharpe, W.E., V.G. Leibfried, W.G. Kimmel, and D.R. Dewalle. 1987. The relationship of water quality and fish occurrence to soils and geology in an area of high hydrogen and sulfate ion deposition. Water Resources Bulletin 13:619-631.

Thompson, P.D., and F.J. Rahel. 1996. Evaluation of depletion-removal electrofishing of brook trout in small rocky mountain streams. North American Journal of Fisheries Management 16:332-339. 
Trojnar, J.R. 1977. Egg hatchability and tolerance of brook trout (Salvelinus fontinalis) fry at low pH. Journal of Fisheries Research Board of Canada 34:574-579.

Welsh, S.A. and S.A. Perry. 1997. Acidification and fish occurrence in the upper Cheat River drainage, West Virginia. Journal of the American Water Resources Association 33(2):423-429.

Witzel, L.D. and H.R. MacCrimmon. 1983. Redd-site selection by brook trout and brown trout in southwestern Ontario streams. Transactions of the American Fisheries Society 112:760-771.

Young, K.A. 1999. Managing the decline of Pacific salmon: metapopulation theory and artificial recolonization as ecological mitigation. Canadian Journal of Fisheries and Aquatic Sciences 56:1700-1706.

Zar, J.H. 1999. Biostatistical analysis. $4^{\text {th }}$ edition. Prentice-Hall, Upper Saddle River, New Jersey. 
Table 1. Summary of sampling dates for the study.

\begin{tabular}{lll}
\hline Parameter measured & \multicolumn{1}{c}{ Dates } & Areas sampled \\
\hline brook trout populations & $\begin{array}{l}\text { June 12 - June 30, 2000 } \\
\text { August 8 - September 1, 2000 } \\
\text { October 6 - October 18, 2000 } \\
\text { June 6 - June 20, 2000 }\end{array}$ & study sites \\
spawning activity & October 4 - November 20, 2000 & entire watershed \\
stream micro-habitat & April 27 - May 4, 2001 & entire watershed \\
stream alkalinity \& pH & July 18, 2001 and October 29,2001 & study sites \\
\hline
\end{tabular}


Table 2. Seasonal size classes of brook trout for the study period.

\begin{tabular}{lccc}
\hline & \multicolumn{3}{c}{ Size-class (standard length) } \\
\hline Season & Juvenile & Small adult & Large adult \\
\hline Spring (2000) & $<60 \mathrm{~mm}$ & $60-100 \mathrm{~mm}$ & $>100 \mathrm{~mm}$ \\
Summer & $<75 \mathrm{~mm}$ & $75-120 \mathrm{~mm}$ & $>120 \mathrm{~mm}$ \\
Fall & $<85 \mathrm{~mm}$ & $85-125 \mathrm{~mm}$ & $>125 \mathrm{~mm}$ \\
Spring $(2001)$ & $<50 \mathrm{~mm}$ & $50-100 \mathrm{~mm}$ & $>100 \mathrm{~mm}$ \\
\hline
\end{tabular}


Table 3. Results of multiple regression analysis between spawning locations and stream habitat parameters.

\begin{tabular}{lcccc}
\hline Variable & F-value & df & $\mathrm{r}^{2}$-value & p-value \\
\hline Basin Area & 24.88 & 10 & 0.7343 & 0.0008 \\
Alkalinity & 5.89 & 10 & 0.1127 & 0.0413 \\
Total Cover & 5.53 & 10 & 0.0675 & 0.0510 \\
Full Model & 24.96 & 10 & 0.9145 & 0.0004 \\
\hline
\end{tabular}


Table 4. Results of fish community sampling in Second Fork study sites .

\begin{tabular}{|c|c|c|c|c|}
\hline Season & Stream & Site\# & Species & \# Captured \\
\hline \multirow[t]{34}{*}{ Spring (2000) } & Second Fork & 1 & Campostoma anomalum & 2 \\
\hline & & & Clinostomus funduloides & 40 \\
\hline & & & Cottus bairdi & 125 \\
\hline & & & Etheostoma flabellare & 44 \\
\hline & & & Rhinichthys atratulus & 42 \\
\hline & & & Rhinichthys cataractae & 30 \\
\hline & & & Semotilus atromaculatus & 11 \\
\hline & & & Salvelinus fontinalis & 36 \\
\hline & Second Fork & 2 & Campostoma anomalum & 3 \\
\hline & & & Clinostomus funduloides & 26 \\
\hline & & & Cottus bairdi & 75 \\
\hline & & & Etheostoma flabellare & 5 \\
\hline & & & Rhinichthys atratulus & 16 \\
\hline & & & Rhinichthys cataractae & 15 \\
\hline & & & Onchorhynchus mykiss & 2 \\
\hline & & & Salvelinus fontinalis & 50 \\
\hline & Second Fork & 3 & Cottus bairdi & 47 \\
\hline & & & Hypentelium nigricans & 5 \\
\hline & & & Rhinichthys cataractae & 8 \\
\hline & & & Salvelinus fontinalis & 48 \\
\hline & Second Fork & 4 & Cottus bairdi & 32 \\
\hline & & & Hypentelium nigricans & 1 \\
\hline & & & Rhinichthys atratulus & 1 \\
\hline & & & Rhinichthys cataractae & 2 \\
\hline & & & Salvelinus fontinalis & 37 \\
\hline & Second Fork & 5 & Cottus bairdi & 28 \\
\hline & & & Hypentelium nigricans & 3 \\
\hline & & & Semotilus atromaculatus & 3 \\
\hline & & & Salvelinus fontinalis & 25 \\
\hline & Shaft Run & 6 & Cottus bairdi & 43 \\
\hline & & & Salvelinus fontinalis & 58 \\
\hline & Second Fork & 7 & Cottus bairdi & 17 \\
\hline & & & Hypentelium nigricans & 4 \\
\hline & & & Salvelinus fontinalis & 35 \\
\hline
\end{tabular}




\begin{tabular}{|c|c|c|c|c|}
\hline Season & Stream & Site\# & Species & \# Captured \\
\hline \multirow[t]{5}{*}{ Spring(2000) } & Odey Run & 8 & Cottus bairdi & 26 \\
\hline & & & Salvelinus fontinalis & 37 \\
\hline & Odey Run & 9 & Salvelinus fontinalis & 23 \\
\hline & le Odey Run & 10 & Salvelinus fontinalis & 40 \\
\hline & Second Fork & 11 & Salvelinus fontinalis & 27 \\
\hline \multirow[t]{27}{*}{ Summer(2000) } & Second Fork & 1 & Campostoma anomalum & 2 \\
\hline & & & Catostomus commersoni & 7 \\
\hline & & & Clinostomus funduloides & 31 \\
\hline & & & Cottus bairdi & 56 \\
\hline & & & Etheostoma flabellare & 24 \\
\hline & & & Hypentelium nigricans & 8 \\
\hline & & & Nocomis micropogon & 5 \\
\hline & & & Phoxinus oreas & 3 \\
\hline & & & Rhinichthys atratulus & 105 \\
\hline & & & Semotilus atromaculatus & 6 \\
\hline & & & Rhinichthys cataractae & 17 \\
\hline & & & Salmo trutta & 1 \\
\hline & & & Salvelinus fontinalis & 32 \\
\hline & Second Fork & 2 & Catostomus commersoni & 7 \\
\hline & & & Clinostomus funduloides & 24 \\
\hline & & & Cottus bairdi & 47 \\
\hline & & & Etheostoma flabellare & 14 \\
\hline & & & Hypentelium nigricans & 6 \\
\hline & & & Rhinichthys atratulus & 68 \\
\hline & & & Rhinichthys cataractae & 18 \\
\hline & & & Salvelinus fontinalis & 44 \\
\hline & & & Onchorhyncus mykiss & 2 \\
\hline & Second Fork & 3 & Campostoma anomalum & 1 \\
\hline & & & Cottus bairdi & 25 \\
\hline & & & Rhinichthys atratulus & 26 \\
\hline & & & Rhinichthys cataractae & 15 \\
\hline & & & Salvelinus fontinalis & 28 \\
\hline
\end{tabular}




\begin{tabular}{|c|c|c|c|c|}
\hline Season & Stream & Site\# & Species & \# Captured \\
\hline \multirow[t]{6}{*}{ Summer(2000) } & Second Fork & 4 & $\begin{array}{l}\text { Catostomus commersoni } \\
\text { Clinostomus funduloides } \\
\text { Cottus bairdi } \\
\text { Hypentelium nigricans } \\
\text { Rhinichthys atratulus } \\
\text { Rhinichthys cataractae } \\
\text { Salvelinus fontinalis }\end{array}$ & $\begin{array}{r}7 \\
4 \\
25 \\
10 \\
22 \\
5 \\
37\end{array}$ \\
\hline & Second Fork & 5 & $\begin{array}{l}\text { Campostoma anomalum } \\
\text { Catostomus commersoni } \\
\text { Clinostomus funduloides } \\
\text { Cottus bairdi } \\
\text { Hypentelium nigricans } \\
\text { Rhinichthys atratulus } \\
\text { Rhinichthys cataractae } \\
\text { Salvelinus fontinalis }\end{array}$ & $\begin{array}{r}1 \\
9 \\
2 \\
50 \\
4 \\
3 \\
2 \\
35\end{array}$ \\
\hline & Shaft Run & 6 & $\begin{array}{l}\text { Cottus bairdi } \\
\text { Salvelinus fontinalis }\end{array}$ & $\begin{array}{l}11 \\
41\end{array}$ \\
\hline & Second Fork & 7 & $\begin{array}{l}\text { Cottus bairdi } \\
\text { Catostomus commersoni } \\
\text { Salvelinus fontinalis }\end{array}$ & $\begin{array}{r}12 \\
1 \\
29\end{array}$ \\
\hline & Odey Run & 8 & $\begin{array}{l}\text { Catostomus commersoni } \\
\text { Cottus bairdi } \\
\text { Hypentelium nigricans } \\
\text { Salvelinus fontinalis }\end{array}$ & $\begin{array}{r}2 \\
52 \\
2 \\
28\end{array}$ \\
\hline & Odey Run & 9 & Salvelinus fontinalis & 24 \\
\hline Littl & le Odey Run & 10 & Salvelinus fontinalis & 73 \\
\hline & Second Fork & 11 & Salvelinus fontinalis & 31 \\
\hline
\end{tabular}




\begin{tabular}{|c|c|c|c|c|}
\hline Season & Stream & Site\# & Species & \# Captured \\
\hline \multirow[t]{38}{*}{ Fall(2000) } & Second Fork & 1 & Campostoma anomalum & 72 \\
\hline & & & Catostomus commersoni & 5 \\
\hline & & & Clinostomus funduloides & 68 \\
\hline & & & Cottus bairdi & 70 \\
\hline & & & Etheostoma flabellare & 16 \\
\hline & & & Hypentelium nigricans & 10 \\
\hline & & & Phoxinus oreas & 15 \\
\hline & & & Rhinichthys atratulus & 178 \\
\hline & & & Rhinichthys cataractae & 21 \\
\hline & & & Semotilus atromaculatus & 12 \\
\hline & & & Salvelinus fontinalis & 24 \\
\hline & Second Fork & 2 & Campostoma anomalum & 4 \\
\hline & & & Catostomus commersoni & 7 \\
\hline & & & Clinostomus funduloides & 27 \\
\hline & & & Cottus bairdi & 84 \\
\hline & & & Etheostoma flabellare & 3 \\
\hline & & & Rhinichthys atratulus & 26 \\
\hline & & & Rhinichthys cataractae & 12 \\
\hline & & & Semotilus atromaculatus & 1 \\
\hline & & & Salvelinus fontinalis & 33 \\
\hline & Second Fork & 3 & Catostomus commersoni & 3 \\
\hline & & & Clinostomus funduloides & 9 \\
\hline & & & Cottus bairdi & 40 \\
\hline & & & Etheostoma flabellare & 1 \\
\hline & & & Rhinichthys atratulus & 1 \\
\hline & & & Rhinichthys cataractae & 9 \\
\hline & & & Salvelinus fontinalis & 36 \\
\hline & Second Fork & 4 & Catostomus commersoni & 11 \\
\hline & & & Clinostomus funduloides & 1 \\
\hline & & & Cottus bairdi & 55 \\
\hline & & & Rhinichthys cataractae & 1 \\
\hline & & & Salvelinus fontinalis & 28 \\
\hline & Second Fork & 5 & Catostomus commersoni & \\
\hline & & & Cottus bairdi & 61 \\
\hline & & & Hypentelium nigricans & 2 \\
\hline & & & Semotilus atromaculatus & 1 \\
\hline & & & Rhinichthys cataractae & 2 \\
\hline & & & Salvelinus fontinalis & 19 \\
\hline
\end{tabular}




\begin{tabular}{|c|c|c|c|c|}
\hline Season & Stream & Site\# & Species & \# Captured \\
\hline \multirow[t]{10}{*}{ Fall(2000) } & Shaft Run & 6 & Cottus bairdi & 12 \\
\hline & & & Salvelinus fontinalis & 36 \\
\hline & Second Fork & 7 & Cottus bairdi & 25 \\
\hline & & & Salvelinus fontinalis & 15 \\
\hline & Odey Run & 8 & Catostomus commersoni & 1 \\
\hline & & & Cottus bairdi & 51 \\
\hline & & & Salvelinus fontinalis & 25 \\
\hline & Odey Run & 9 & Salvelinus fontinalis & 20 \\
\hline & L.Odey Run & 10 & Salvelinus fontinalis & 71 \\
\hline & Second Fork & 11 & Salvelinus fontinalis & 29 \\
\hline
\end{tabular}


Table 5. Seasonal brook trout capture data for eleven study sites within the Second Fork watershed.

\begin{tabular}{|c|c|c|c|c|}
\hline Site & Season & Juveniles & Sm. adults & Lg. adults \\
\hline 1 & Spring $(2000)$ & 15 & 11 & 10 \\
\hline 1 & Summer & 13 & 14 & 5 \\
\hline 1 & Fall & 14 & 6 & 4 \\
\hline 1 & Spring $(2001)$ & 7 & 11 & 12 \\
\hline 2 & $\operatorname{Spring}(2000)$ & 18 & 18 & 14 \\
\hline 2 & Summer & 12 & 22 & 10 \\
\hline 2 & Fall & 15 & 12 & 3 \\
\hline 2 & Spring(2001) & 32 & 22 & 20 \\
\hline 3 & Spring(2000) & 14 & 17 & 17 \\
\hline 3 & Summer & 5 & 12 & 11 \\
\hline 3 & Fall & 10 & 17 & 9 \\
\hline 3 & Spring(2001) & 19 & 14 & 12 \\
\hline 4 & Spring(2000) & 7 & 15 & 15 \\
\hline 4 & Summer & 11 & 10 & 16 \\
\hline 4 & Fall & 11 & 13 & 4 \\
\hline 4 & Spring(2001) & 18 & 17 & 10 \\
\hline 5 & Spring $(2000)$ & 5 & 11 & 9 \\
\hline 5 & Summer & 14 & 13 & 8 \\
\hline 5 & Fall & 8 & 10 & 1 \\
\hline 5 & Spring(2001) & 5 & 5 & 7 \\
\hline 6 & Spring(2000) & 23 & 27 & 8 \\
\hline 6 & Summer & 23 & 17 & 1 \\
\hline 6 & Fall & 17 & 15 & 4 \\
\hline 6 & Spring(2001) & 42 & 16 & 10 \\
\hline 7 & Spring(2000) & 11 & 18 & 6 \\
\hline 7 & Summer & 16 & 11 & 2 \\
\hline 7 & Fall & 9 & 6 & 0 \\
\hline 7 & Spring(2001) & 1 & 8 & 3 \\
\hline 8 & Spring(2000) & 18 & 9 & 9 \\
\hline 8 & Summer & 9 & 14 & 5 \\
\hline 8 & Fall & 14 & 8 & 3 \\
\hline 8 & Spring(2001) & 31 & 9 & 3 \\
\hline 9 & Spring(2000) & 9 & 7 & 7 \\
\hline 9 & Summer & 11 & 10 & 3 \\
\hline 9 & Fall & 14 & 6 & 0 \\
\hline 9 & Spring $(2001)$ & 0 & 10 & 8 \\
\hline 10 & Spring(2000) & 16 & 19 & 5 \\
\hline 10 & Summer & 44 & 21 & 8 \\
\hline 10 & Fall & 50 & 21 & 0 \\
\hline 10 & Spring(2001) & 50 & 46 & 8 \\
\hline 11 & Spring $(2000)$ & 8 & 10 & 9 \\
\hline 11 & Summer & 13 & 10 & 8 \\
\hline 11 & Fall & 10 & 13 & 6 \\
\hline 11 & Spring(2001) & 5 & 4 & 8 \\
\hline
\end{tabular}


Table 6. Summary of stream $\mathrm{pH}$ measurements taken within the Second Fork watershed. Data includes continuous $\mathrm{pH}$ data (2 hour intervals) for Site \#4 (4-20-01 - 5-31-01), Site \#5 (4-20-01 - 5-21-01), Site \#7 (4-20-01 - 5-31-01), Site \#8 (8-09-00 - 10-28-00), Site \#9 (2-03-01 - 4-0700), Site \#10 (02-03-01 - 4-07-01).

\begin{tabular}{ccccc}
\hline SITE & MEAN & STD.DEV & MAX & MIN \\
\hline 1 & 6.50 & 0.11 & 6.68 & 6.39 \\
2 & 6.47 & 0.53 & 7.28 & 5.72 \\
3 & 6.56 & 0.25 & 7.01 & 6.32 \\
4 & 6.74 & 0.66 & 7.48 & 5.26 \\
5 & 6.82 & 0.53 & 7.32 & 5.25 \\
6 & 6.61 & 0.34 & 7.04 & 6.11 \\
7 & 6.76 & 0.62 & 7.48 & 5.10 \\
8 & 6.43 & 0.54 & 7.50 & 3.65 \\
9 & 5.74 & 0.58 & 6.62 & 3.54 \\
10 & 7.25 & 0.50 & 7.80 & 5.47 \\
11 & 5.55 & 0.46 & 6.59 & 4.45 \\
\hline
\end{tabular}


Table 7. Summary of baseflow mean stream $\mathrm{pH}$ levels measured within the eleven study sites. Means for each site are the result of measurements taken on 7-18-01 and 10-29-01.

\begin{tabular}{cccccc}
\hline & \multicolumn{5}{c}{ Summary } \\
\hline Site & $\mathrm{pH}$ & Mean & Std.dev & Max & Min \\
\hline 1 & 6.55 & 6.57 & 0.44 & 7.24 & 6.06 \\
3 & 6.65 & & & \\
4 & 6.68 & & & \\
5 & 6.11 & & & \\
6 & 6.72 & & \\
7 & 7.17 & & \\
8 & 6.07 & & \\
9 & 6.90 & & \\
10 & 6.06 & & \\
\hline & 6.09 & & \\
\hline
\end{tabular}


Table 8. Summary of baseflow mean stream alkalinity levels measured within the eleven study sites. Means for each site are the result of measurements taken on 7-18-01 and 10-29-01.

\begin{tabular}{|c|c|c|c|c|c|}
\hline & & & Summary & & \\
\hline Site & Alkalinity $\left(\mathrm{mg} / \mathrm{L} \mathrm{CaCO}_{3}\right)$ & Mean & Std.dev & Max & Min \\
\hline 1 & 8.9 & 10.6 & 5.63 & 22.4 & 4.2 \\
\hline 2 & 8.4 & & & & \\
\hline 3 & 6.6 & & & & \\
\hline 4 & 10.1 & & & & \\
\hline 5 & 9.7 & & & & \\
\hline 6 & 17.2 & & & & \\
\hline 7 & 7.6 & & & & \\
\hline 8 & 16.2 & & & & \\
\hline 9 & 5.3 & & & & \\
\hline 10 & 22.4 & & & & \\
\hline 11 & 4.2 & & & & \\
\hline
\end{tabular}


Table 9. Summary of stream pH values recorded during early spring (February 10 - April 7) in two headwater study sites.

\begin{tabular}{lcc}
\hline & \multicolumn{2}{c}{ STREAM } \\
\cline { 2 - 3 } VARIABLE & LITTLE ODEY (Site \# 10) & UPPER ODEY (Site \# 9) \\
\hline N & 754 & 754 \\
pH values & 7.29 & 5.74 \\
Mean & 0.48 & 0.58 \\
Std. Dev. & 7.48 & 6.45 \\
Max & 5.47 & 4.26 \\
Min & 1 & 7 \\
Episodes below pH 5.5 & 4 & 32, 26, 24, 28, 36, 70, 14 \\
Hours between pH 5.5 and 5.0 & 0 & 5 \\
Episodes below pH 5.0 & 0 & $24,4,24$ \\
Hours between pH 5.0 and 4.5 & 0 & 74,2 \\
Episodes below pH 4.5 & 0 & 24 \\
Hours below pH 4.5 & & \\
\hline
\end{tabular}


Table 10. Results of micro-habitat survey parameters for all study sites.

\begin{tabular}{clllcclc}
\hline Site & $\begin{array}{l}\text { Wetted } \\
\text { width }(\mathrm{m})\end{array}$ & $\begin{array}{l}\text { Basin } \\
\text { area }\left(\mathrm{km}^{2}\right)\end{array}$ & $\begin{array}{l}\text { Canopy } \\
\text { cover }(\%)\end{array}$ & $\begin{array}{c}\text { Average } \\
\text { depth }(\mathrm{m})\end{array}$ & $\begin{array}{l}\text { Total available } \\
\text { cover }(\%)\end{array}$ & $\begin{array}{l}\text { Suitable } \\
\text { spawning }(\%)\end{array}$ & $\begin{array}{c}\text { Alkalinity } \\
\left(\mathrm{mg} / \mathrm{L} \mathrm{CaCO}_{3}\right)\end{array}$ \\
\hline 1 & 7.5 & 15.0 & 63 & 0.30 & 40 & 5 & 8.9 \\
2 & 6.5 & 12.0 & 48 & 0.33 & 55 & 15 & 8.4 \\
3 & 5.5 & 11.5 & 53 & 0.40 & 70 & 15 & 6.6 \\
4 & 5.7 & 10.0 & 43 & 0.40 & 45 & 15 & 10.1 \\
5 & 5.0 & 8.0 & 63 & 0.38 & 50 & 10 & 9.7 \\
6 & 3.0 & 1.50 & 85 & 0.20 & 40 & 20 & 17.2 \\
7 & 5.3 & 5.25 & 68 & 0.25 & 55 & 15 & 7.6 \\
8 & 4.0 & 2.50 & 65 & 0.30 & 45 & 20 & 16.2 \\
9 & 2.3 & 1.25 & 88 & 0.28 & 40 & 20 & 5.3 \\
10 & 3.0 & 0.75 & 15 & 0.25 & 50 & 45 & 22.4 \\
11 & 5.7 & 4.25 & 43 & 0.38 & 50 & 20 & 4.2 \\
\hline
\end{tabular}


Table 11. Results of linear regression of spawning intensity and size class density. Densities with a n.s. signify a non-significant relationship between the variables.

\begin{tabular}{|c|c|c|c|c|c|}
\hline Season & Dependent variable & F-value & df & $r^{2}$ & $\mathrm{p}$-value \\
\hline \multirow[t]{3}{*}{$\operatorname{Spring}(2000)$} & juvenile density & 68.49 & 10 & 0.88 & 0.0001 \\
\hline & small adult density & 17.11 & 10 & 0.66 & $<0.01$ \\
\hline & large adult density & 0.63 & 10 & 0.07 & n.s. \\
\hline \multirow[t]{3}{*}{ Summer(2000) } & juvenile density & 29.12 & 10 & 0.76 & 0.0004 \\
\hline & small adult density & 40.12 & 10 & 0.82 & 0.0001 \\
\hline & large adult density & 1.63 & 10 & 0.15 & n.s. \\
\hline \multirow[t]{3}{*}{ Fall(2000) } & juvenile density & 28.15 & 10 & 0.76 & 0.0005 \\
\hline & small adult density & 21.62 & 10 & 0.71 & 0.0012 \\
\hline & large adult density & 0.05 & 10 & 0.01 & n.s. \\
\hline \multirow[t]{3}{*}{ Spring(2001) } & juvenile density & 23.46 & 10 & 0.72 & 0.0009 \\
\hline & small adult density & 20.85 & 10 & 0.70 & 0.0014 \\
\hline & large adult density & 0.05 & 10 & 0.01 & n.s. \\
\hline
\end{tabular}


Table 12. Results of step-wise multiple linear-regression analysis between seasonal large adult density and stream habitat parameters.

\begin{tabular}{|c|c|c|c|c|c|c|}
\hline season & habitat variable & F-value & $\mathrm{df}$ & $\left(r^{2}\right)$ & relationship & p-value \\
\hline \multirow[t]{3}{*}{ spring (2000) } & wetted width & 3.03 & 10 & 0.2521 & - & 0.12 \\
\hline & $\%$ instream cover & 3.72 & 10 & 0.2375 & + & 0.09 \\
\hline & full model & 3.84 & 10 & 0.4896 & & 0.07 \\
\hline \multirow[t]{4}{*}{ summer (2000) } & canopy cover & 37.47 & 10 & 0.6538 & - & 0.003 \\
\hline & wetted width & 8.19 & 10 & 0.1751 & - & 0.02 \\
\hline & average depth & 4.71 & 10 & 0.0688 & + & 0.07 \\
\hline & full model & 20.48 & 10 & 0.8977 & & 0.008 \\
\hline \multirow[t]{3}{*}{ fall (2000) } & $\%$ stream margin & 4.36 & 10 & 0.3261 & - & 0.07 \\
\hline & $\%$ spawning habitat & 4.21 & 10 & 0.2325 & + & 0.07 \\
\hline & full model & 5.06 & 10 & 0.5586 & & 0.04 \\
\hline \multirow[t]{2}{*}{ spring (2001) } & $\%$ bank cover & 4.20 & 10 & 0.3180 & + & 0.07 \\
\hline & full model & 4.20 & 10 & 0.3180 & & 0.07 \\
\hline
\end{tabular}


Table 13. Results of linear regression analysis between seasonal size class density. Densities with a n.s. signify a non-significant relationship between densities.

\begin{tabular}{lllllll}
\hline size class & independent season & dependent season & df & F-value & $\mathrm{r}^{2}$ & p-value \\
\hline juvenile & Spring 2000 & Summer 2000 & 10 & 14.10 & 0.61 & 0.005 \\
& Summer 2000 & Fall 2000 & 10 & 185.56 & 0.95 & $<0.001$ \\
& Fall 2000 & Spring 2001 & 10 & 25.24 & 0.74 & $<0.001$ \\
& Spring 2000 & Spring 2001 & 10 & 13.12 & 0.59 & 0.006 \\
\hline \multirow{2}{*}{ small adult } & Spring 2000 & Summer 2000 & 10 & 21.10 & 0.70 & 0.001 \\
& Summer 2000 & Fall 2000 & 10 & 50.79 & 0.85 & $<0.001$ \\
& Fall 2000 & Spring 2001 & 10 & 182.30 & 0.95 & $<0.001$ \\
& Spring 2000 & Spring 2001 & 10 & 12.12 & 0.57 & 0.007 \\
\hline \multirow{2}{*}{ large adult } & Spring 2000 & Summer 2000 & 10 & 1.11 & 0.11 & n.s. \\
& Summer 2000 & Fall 2000 & 10 & 0.03 & 0.01 & n.s. \\
& Fall 2000 & Spring 2001 & 10 & 0.23 & 0.02 & n.s. \\
& Spring 2000 & Spring 2001 & 10 & 1.64 & 0.15 & n.s. \\
\hline
\end{tabular}




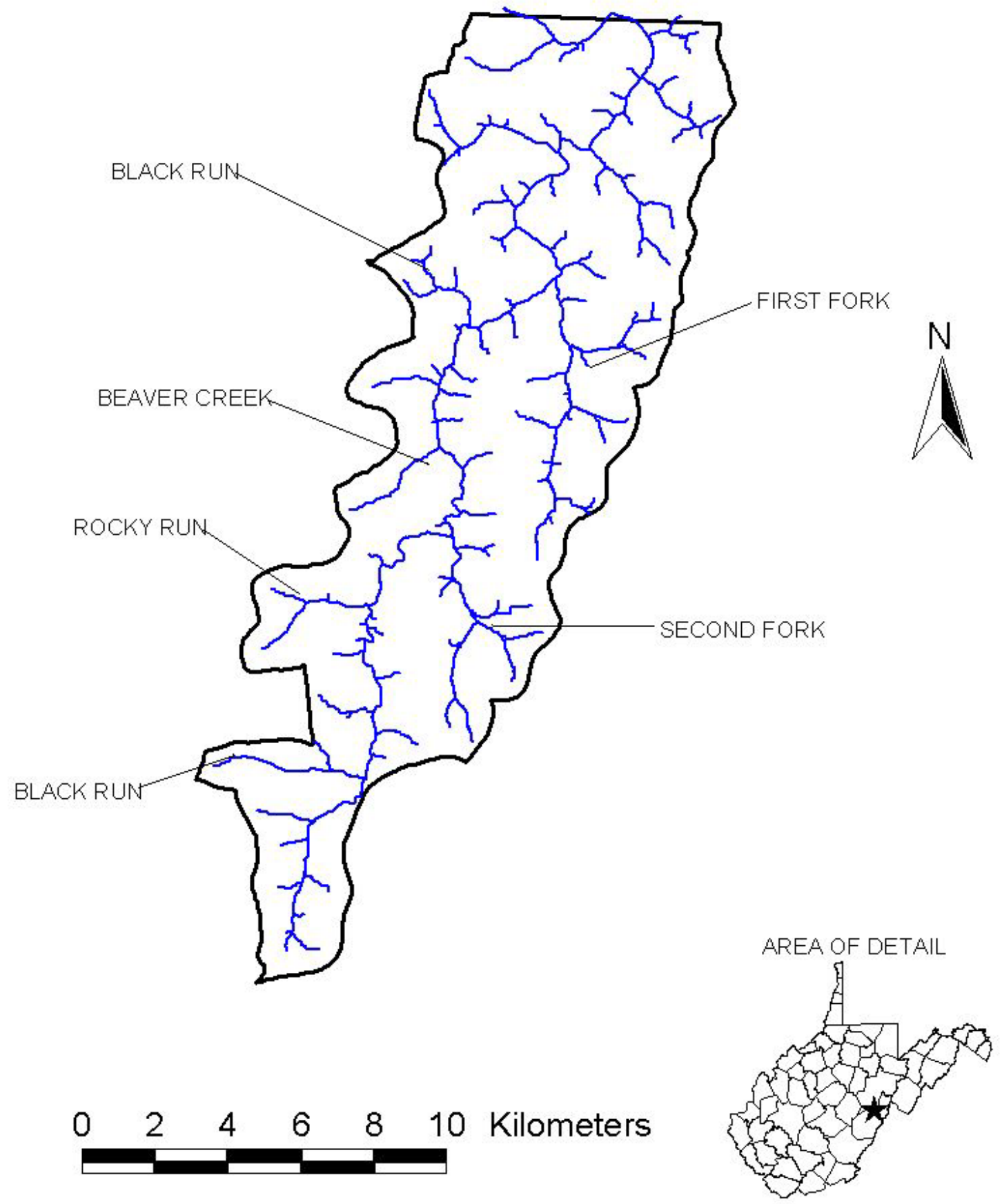

Figure 1. The upper Shavers Fork watershed of eastern West Virginia. 

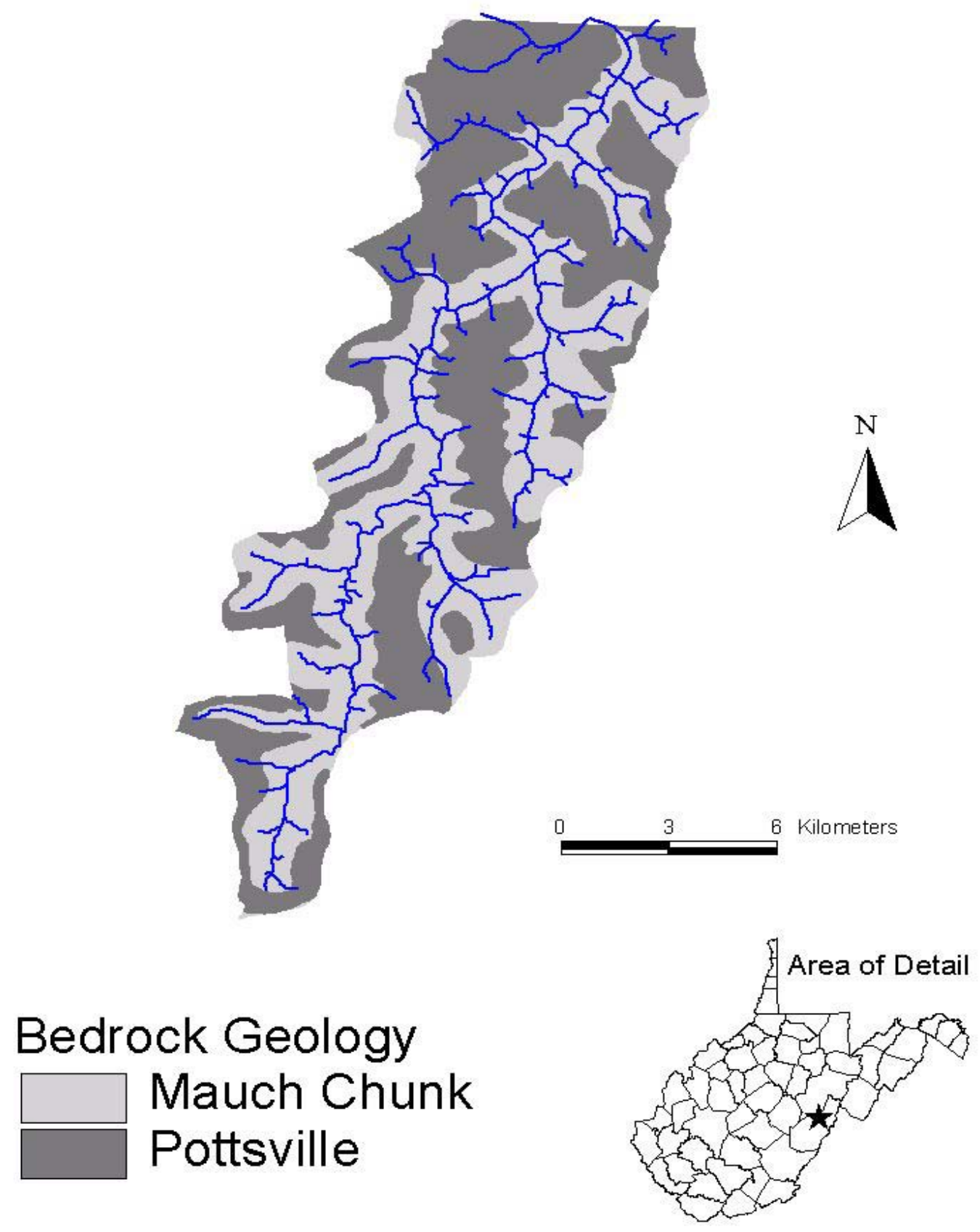

Figure 2. Spatial variation in the bedrock geology within the upper Shavers Fork watershed. 


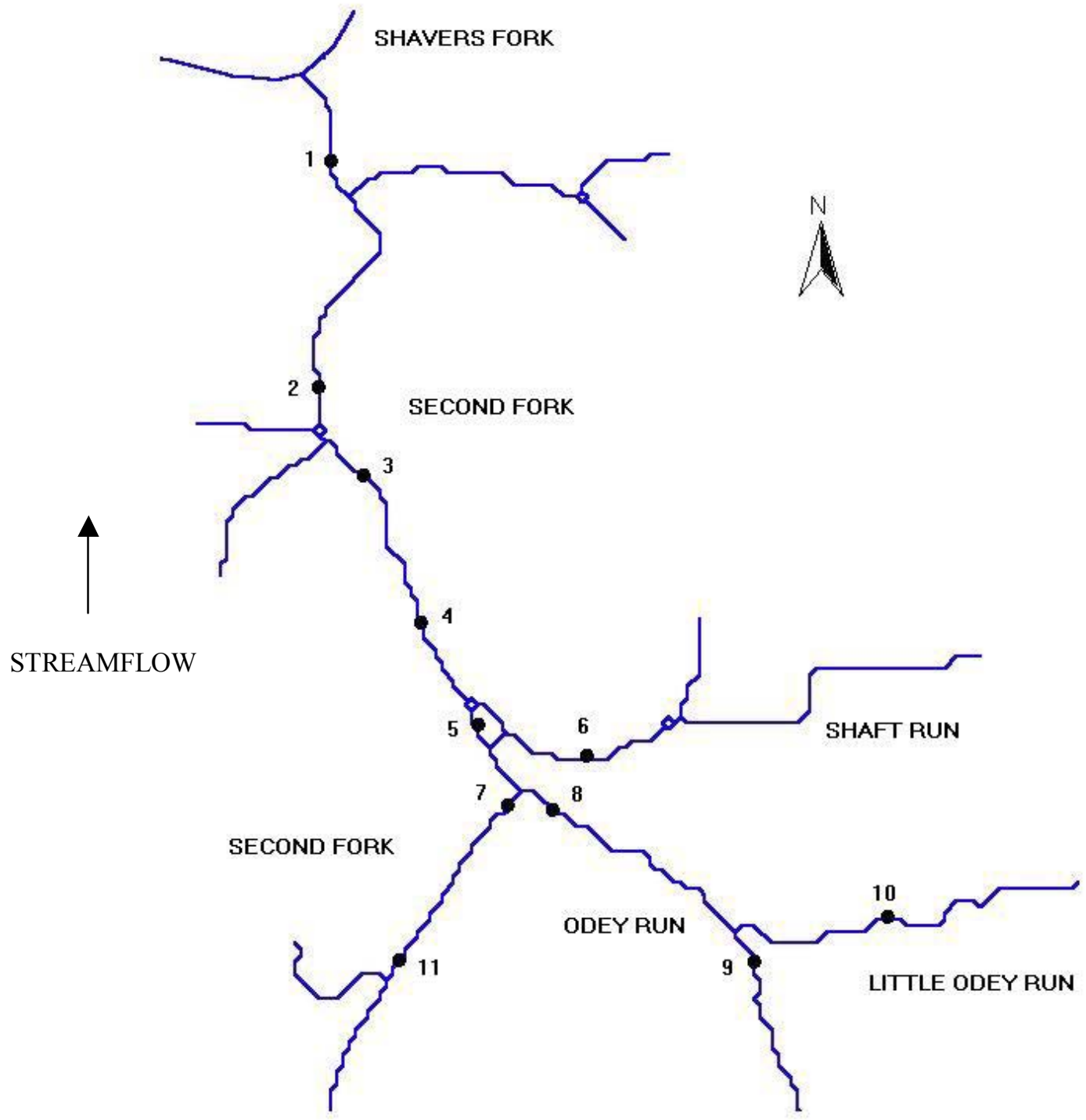

- Study Sites

$\begin{array}{lll}0 & 0.3 \quad 0.6 & \text { Kilometers }\end{array}$

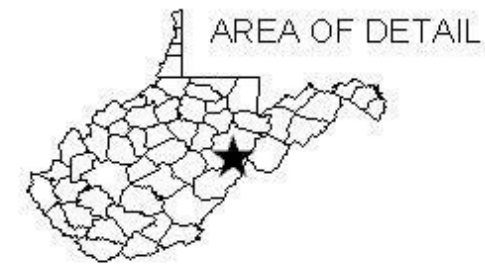

Figure 3. The Second Fork watershed, located in the Monongahela National Forest of eastern West Virginia, with the locations of the eleven sampling sites. 
Spring 2000

Summer 2000
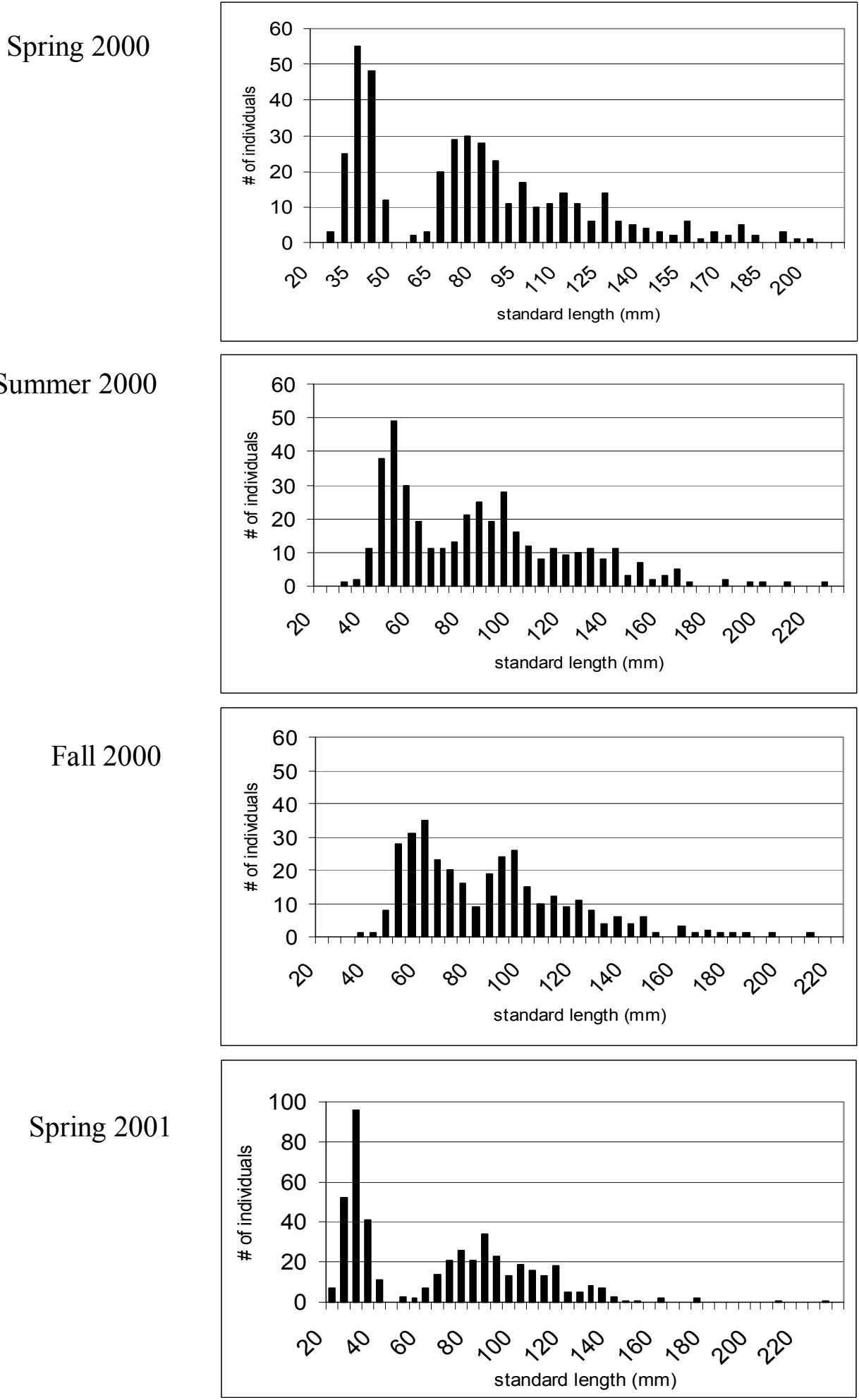

Figure 4. Seasonal length frequency histograms from pooled data for eleven study sites within the Second Fork watershed. 


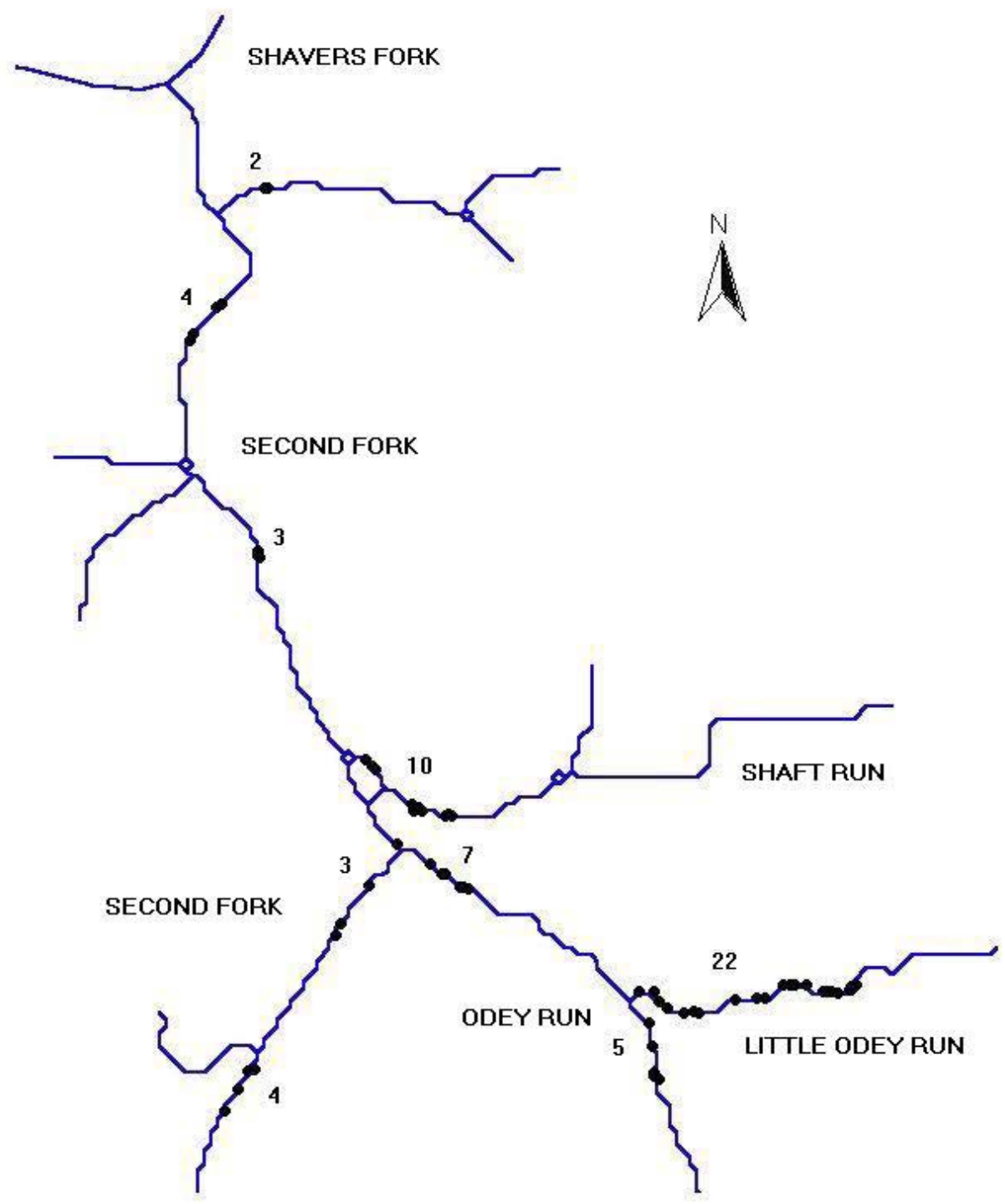

- Spawning locations
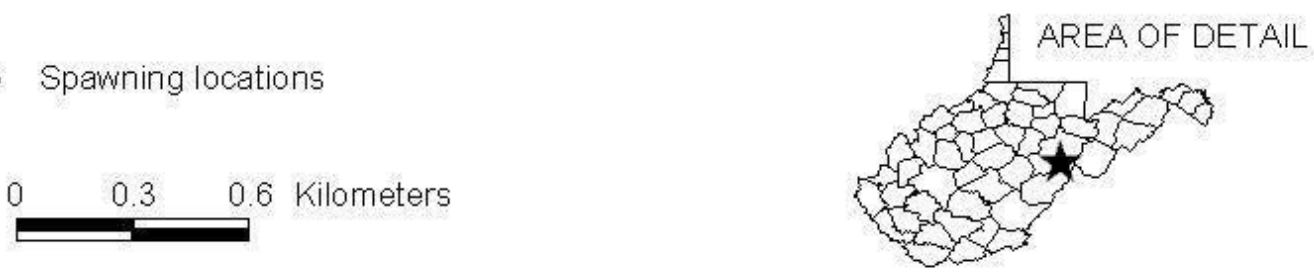

Figure 5. The results of the brook trout spawning activity surveys for fall 2000 . The numbers represent the number of identified spawning locations for that section of stream. 


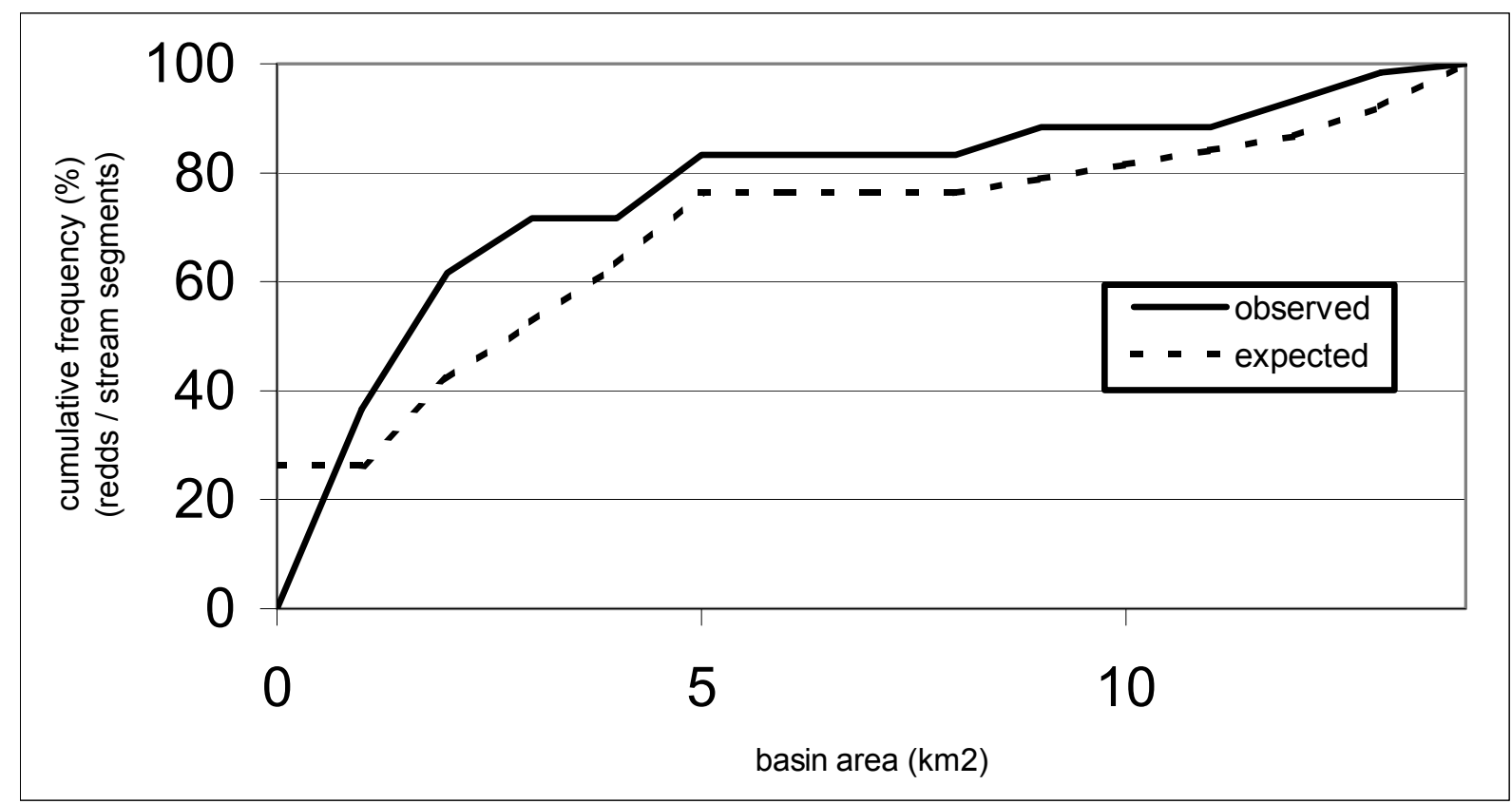

Figure 6 . The relationship between the cumulative frequency of redds and stream segments along the continuum of watershed basin area within the Second Fork watershed in fall 2000. 
Juveniles

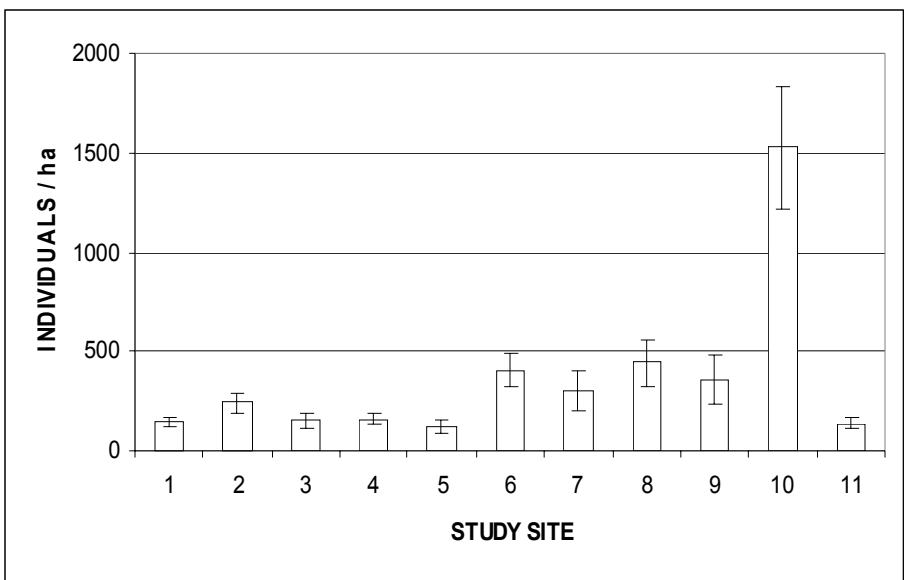

Small adults

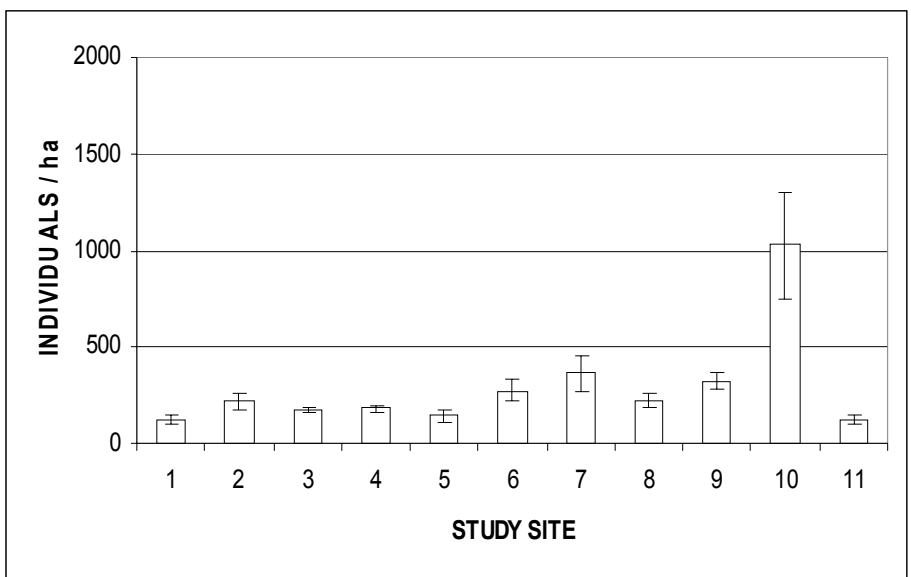

Large adults

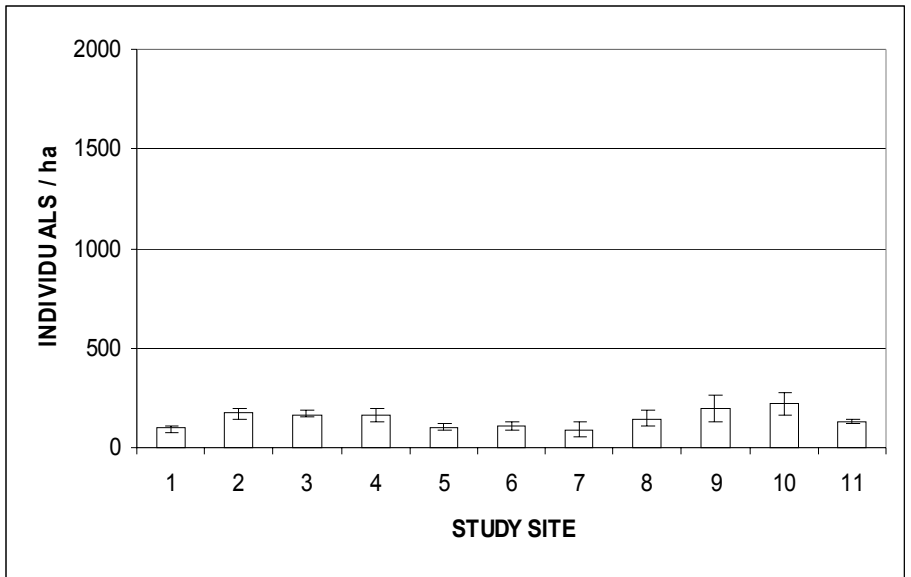

Figure 7. Mean brook trout densities, with error bars, within the Second Fork watershed. 


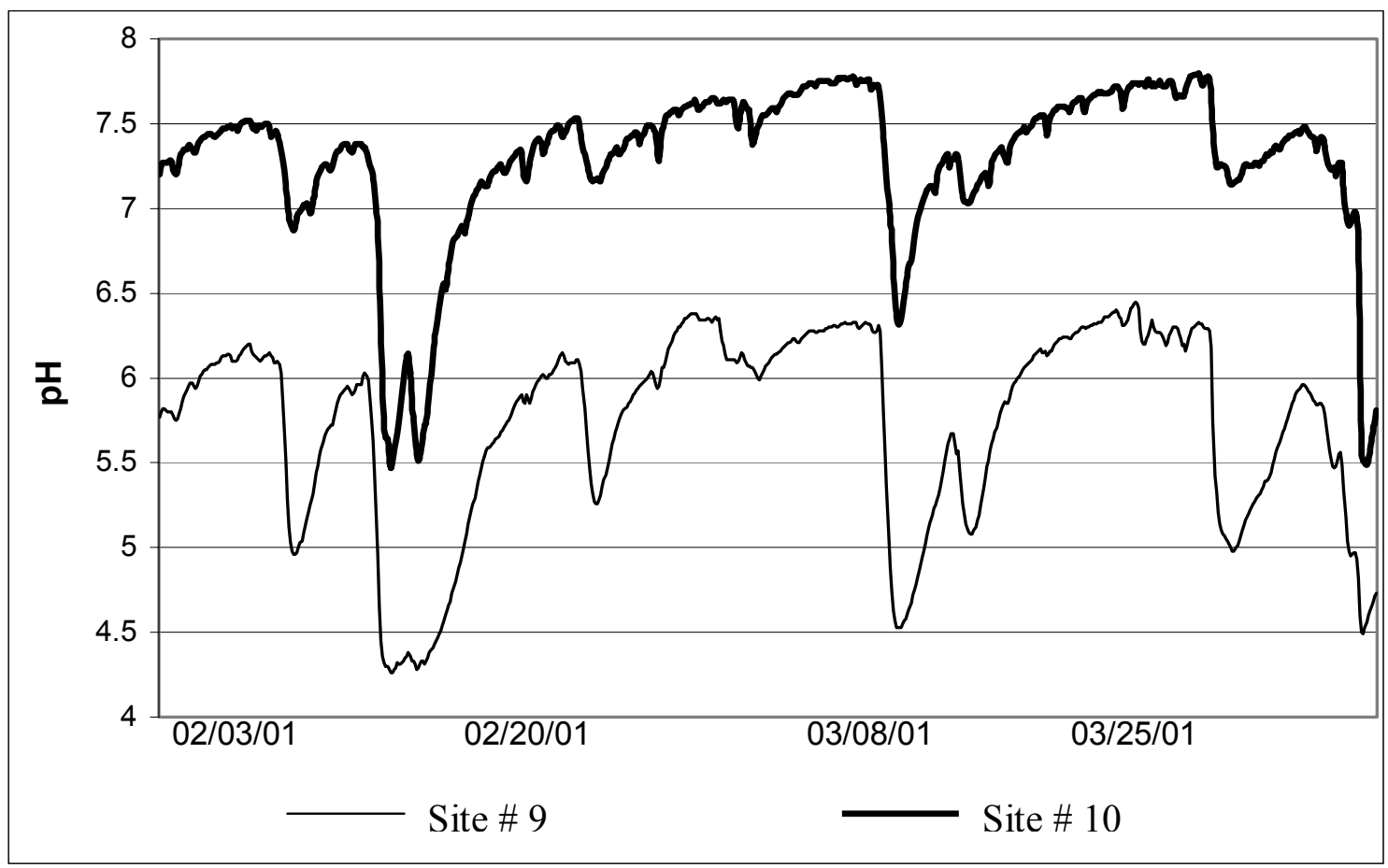

Figure 8. Results of continuous stream pH measurements taken during winter/early spring 2001. Stream pH was recorded every two hours during the period February 32001 to April 72001. 


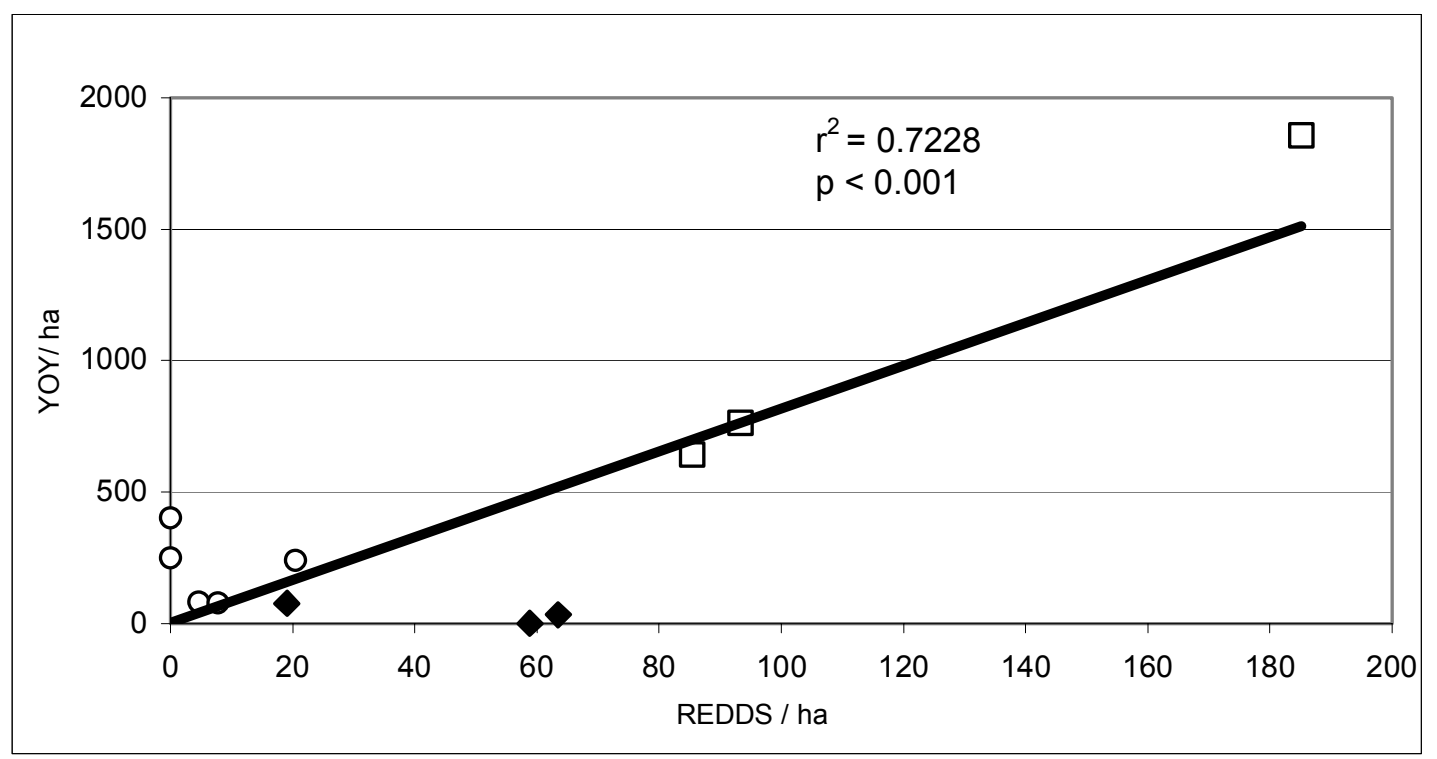

Figure 9. Results of linear regression analysis between brook trout spawning intensity (Fall 2000) and juvenile density (Spring 2001). Black diamonds represent sites with alkalinities of less than or equal to 5 . White circles represent sites that have alkalinities between 5 and 10 . White squares represent sites with alkalinities greater than 10 . 


\section{Chapter 2:}

The influence of spatial arrangement and quality of habitats on residency, growth, and population age structure of brook trout (Salvelinus fontinalis) in a third order tributary. Abstract.-Brook trout require spawning, foraging, and refuge habitats to complete their annual life cycle. Consequently, the relative quality and spatial arrangement of these complementary habitats within a watershed may have a significant influence on trout demography and population dynamics. I conducted a watershed scale mark-recapture study of brook trout inhabiting Second Fork, a $3^{\text {rd }}$ order tributary in eastern West Virginia. Mark recapture data from four seasons (Spring 2000, Summer 2000, Fall 2000, and Spring 2001) and eleven 100m sites were used to quantify spatial and temporal variability in brook trout population age structure, individual growth rates, residency/local survival rates, and average relative fluctuation (ARF). In addition, I used data on water chemistry, stream water depth, and instream habitat features to develop and index of relative site quality. The primary objective of my statistical analyses was to determine if site quality significantly influenced the spatial and temporal dynamics and structure of brook trout populations at the scale of a whole watershed. These analyses determined that brook trout growth rates $\left(\% \mathrm{~d}^{-1}\right)$ were highest from spring to summer for each size class except for large adults, which exhibited no significant difference in growth between summer and winter/spring. Growth rates of small adult brook trout were greatest in study sites with a suitability ranking of medium and lowest in sites with a high suitability ranking. Residency rates (\%) were found to be significantly higher for small adult brook trout than for juveniles and large adults brook trout. Large adult and juvenile brook trout in study sites with high habitat suitability had significantly higher residency rates than in sites with low habitat suitability. The average relative fluctuation (ARF) for brook trout was lowest in Spring 2000 and highest in Fall 2000 for 
large adults, and highest in Spring 2001 for juveniles and small adults. I found population fluctuations to be spatially influenced with highest fluctuations occurring in the headwaters of Second Fork. The results of the study show that brook trout residency rates are influenced by the availability of complementary habitats and that seasonal changes in habitat selection of large adults and vulnerability of juveniles to acidic episodes are causing spatial and temporal fluctuations in brook trout populations in Second Fork.

\section{Introduction}

Complementary habitats are the habitats that animals must move between to complete their annual life cycle (Schlosser 1991, 1995). The basic life cycle of brook trout (Salvelinus fontinalis) requires habitats for spawning, feeding, and refugia, and since the profitability of these habitats can vary greatly over space and time, individuals may be required to move relatively long distances to access these habitats (Schlosser 1995). The energetic gains of moving into profitable stream positions, as well as the energetic cost and risk of mortality, can greatly affect the location and densities of individuals within a section of stream at any point in time (Hughes and Dill 1990, Beard and Carline 1991, Hayes et al. 1996, Hughes 1998, Schlosser 1995, 1998). Additionally, the size-specific habitat requirements of individuals can greatly affect the numbers and size-structure of individuals found seasonally in different areas of a stream (Schlosser 1985, Moore and Gregory 1988, Johnson et al. 1992, Schlosser 1995). Brook trout vary dramatically in size from juvenile to adult, and associated with this variation, individuals exhibit complex patterns of habitat use. Streams are a complex of spatially heterogeneous environments that offer the possibility for spatial segregation of size classes (Schlosser 1991). The combination of spatial and temporal variation in the regulatory effects of food resource 
availability and predation pressures act to further segregate the size classes within a population. The result of these regulatory effects is that different size classes of fish within a population use different areas of the stream to complete the annual life cycle.

Brook trout spawn during the fall season in lakes, ponds and small headwater streams that they inhabit throughout their range. Females search for appropriate microhabitats, often in locations with gravel and groundwater upwelling (Witzel and MacCrimmon 1983, Curry et al. 1995). Groundwater upwelling surrounds the eggs with oxygen rich water and provide buffering from acidic episodes due to the high calcium content of upwelled water. After the spawning season is completed individuals must search for locations that provide refuge from the thermal extremes of winter. During this time of year individuals seek out pools, often associated with large woody debris, and backwaters that allow for a minimum of energetic expenditure due to the low current velocities of these stream channel units (Heifetz et al 1986, Cunjak 1996, Solazzi et al. 2000). These areas may also be important during other seasons especially during years of drought conditions (Riley et al. 1992, Riley and Fausch 1995, Elliott 2000).

The arrival of spring and warmer water temperatures allows individuals to begin to forage more actively. The input of organic matter during the fall provides the energy and nutrients necessary to produce relatively high densities of stream invertebrates during the spring and early summer (Vannote 1980, Schlosser 1995). At this same time, juveniles are emerging from the gravel of spawning locations and begin to seek out microhabitats that provide both foraging opportunities and refuge from high stream discharge. These microhabitats usually exist in stream reaches with large amounts of stream margin that provide refuge from strong current velocities (Moore and Gregory 1988, McLaughlin et al. 1994). The amount and quality of this microhabitat can vary greatly from year to year depending on stream flows and differences in 
stream flow regimes has been shown to be an important determinant of abundance for juvenile fishes in streams (Schlosser 1985). As summer begins to wane, the search for suitable spawning sites begins again. The return of larger individuals into spawning sites may be an important displacement mechanism of juveniles and smaller adults from nursery habitats (Josephson and Youngs 1996) and may allow for access to the relatively high quality foraging sites previously occupied by larger fish.

The movement patterns of brook trout to access seasonally important habitats suggest that the net energetic value of a habitat is a result of the energy received from a location less the energetic cost, with risk of mortality being an important component (Schlosser 1991). Habitat suitability models often attempt to quantify the ecological importance of specific habitat parameters for stream fishes by assigning a value to microhabitats based on frequency of use (Baker and Coon 1997). Quantifying the value of microhabitat by the presence or absence of individuals provides an incomplete picture. The value of microhabitats can be altered by the density and size of individuals occupying nearby locations (Fausch 1984, Hughes 1992) and the spatial arrangement and the energetic costs and rewards of moving between complementary habitats for spawning, feeding, and refugia, necessary to complete the annual cycle (Schlosser and Angermeier 1995). Furthermore, the relatively small number of optimal sites within a landscape can create a distributional pattern in which most individuals occupy sub-optimal positions (Pulliam 1988). When this is the case, an artificially high value would be assigned to inferior habitats. The implications of misclassifying habitats could have severe implications for the effective conservation of species or populations of stream fish.

The overall objective of this study was to relate the quality and spatial arrangement of habitats to the population dynamics of brook trout in the Second Fork watershed. The specific 
objectives of the study were: (1) to develop size-specific habitat suitability criteria for eleven study sites based on the relative availability of complementary habitats; (2) to determine the seasonal and spatial variation in brook trout growth rates; (3) to determine seasonal and spatial patterns in residency rates; and (4) evaluate the role of complementary habitats in determining growth and residency rates for three size classes of brook trout.

\section{Methods}

Study area - My study was conducted within Second Fork, a $3^{\text {rd }}$ order tributary of the upper Shavers Fork, located in the central Appalachian Mountains of eastern West Virginia (Figure 1) (also see study area description in Chapter 1). The headwaters of Second Fork and its tributaries (Sites 6-11) are low gradient $(<3 \%)$ streams with a relatively high availability of cover and suitable spawning habitat. Although spawning activity occurs throughout the headwaters, relatively high stream alkalinities in Shaft Run and Little Odey Run make these streams vital to brook trout recruitment (see Chapter 1). Extreme differences in stream alkalinities, ranging from $23 \mathrm{mg} / \mathrm{L} \mathrm{CaCO}_{3}$ in Little Odey down to $4 \mathrm{mg} / \mathrm{L} \mathrm{CaCO}_{3}$ in the headwaters of Second Fork, allow for large fluctuations in stream $\mathrm{pH}$. The lowest minimum $\mathrm{pH}$ recordings $(<4.0)$ were taken in the headwaters (see Table 6, Chapter 1). Downstream of Shaft Run (Sites 2-5), Second Fork increases in gradient and availability of instream cover (sections could be described as choked with large boulders). The combination of a wider stream channel and a shift in forest composition from a mixed coniferous/deciduous to mixed deciduous, creates patches of open canopy that may affect stream thermal regimes and macroinvertebrate abundance (Hetrick et al. 1998, Bopp 2002). Stream alkalinities in this section of the watershed average $6.5(\mathrm{mg} / \mathrm{L}$ $\mathrm{CaCO}_{3}$ ). Although alkalinities in this section of the watershed are not as high as some headwater 
sites (maximum of $23 \mathrm{mg} / \mathrm{L} \mathrm{CaCO}_{3}$ ), the stream $\mathrm{pH}$ regime is relatively stable with a recorded minimum stream $\mathrm{pH}$ of 5.25 (see Table 6 , Chapter 1). The physical habitat quality of the lower reaches of Second Fork (Site 1) is relatively poor with low availability of instream cover and suitable spawning habitat. The overall value of this section of the watershed to brook trout may be diminished due to its proximity to the Shavers Fork which has significantly higher productivity (Bopp 2002).

Habitat suitability- The results of my stream habitat surveys (see Table 10, Chapter 1) were used to rank sites according to their habitat suitability for three size classes of brook trout. A different combination of habitat variables were selected for each size class, in order to capture the stream habitat suitability of a site for each size class of brook trout (Table 1). The sum of the ranks for the four habitat variables used for each size class (Table 2) was then used to produce a raw suitability score. Due to the odd number of study sites, I labeled the sites with the three highest standardized suitability scores as "high", then next five sites were labeled "medium", and the lowest three sites were labeled as "low".

The percentage of area within a site suitable for spawning and the mean stream alkalinity were used for each size class. Spawning locations are non-substitutable habitat that adults must move to in order to reproduce and redd densities have been shown to be a strong predictor of all size classes of trout, including juveniles and age-1 fish (Beard and Carline 1991). Spawning locations are also the starting point of life for juvenile fishes and often the final destination for adults, especially salmonids. The suitability of foraging and refuge habitats may be determined largely by their spatial relationship to spawning locations. Stream alkalinity has been shown to be positively associated with both trout and stream macroinvertebrate production (Krueger and Waters 1983, Clayton and Menendez 1996, Menendez et al. 1996, Kwak and Waters 1997, 
Clayton et al. 1998) suggesting high potential differences for growth and foraging in streams with different alkalinities. Stream alkalinity is also an important determinant of the severity of acidic episodes that affect populations directly through increased mortality and reduced growth. Habitat quality is also reduced in streams with low alkalinity by forcing stream fishes to move to chemical refugia, usually areas of high groundwater discharge, during these acidic episodes (Carline et al. 1992).

The remaining variables included to determine habitat suitability include a combination stream water depth and cover suitability of a site. Maximum depth and instream cover were included to determine suitability for the largest class of brook trout. Maximum depth was used as a gauge of availability of habitat that could be accessed during periods of thermal extremes in both summer and winter. Adult salmonids have shown a tendency to use deep pools as winter habitat (Cunjak 1996) and refugia from drought conditions (Elliott 2000). Predation pressure from terrestrial piscivores also may alter the habitat selection of adult fish to favor deep pools (Schlosser 1988, 1995). The percent of instream cover was included as an important component in determining energy gain potential. Fausch (1984) proposed that stream salmonids should select microhabitats in areas associated with cover because they provide both access to stream macroinvertebrates caught in the water column while providing relief from the energetic requirements of holding feeding positions directly in the strong current.

Juvenile suitability was determined by ranking sites with regards to the availability of undercut banks and the amount of stream margin. Undercut banks and stream margins are an important habitat component to juvenile salmonids due to their value for predator avoidance, winter habitat, and refuge from high current velocities (Moore and Gregory 1988, Schlosser 1995, Cunjak 1996). 
Habitat suitability for small adult brook trout was determined by incorporating the percent availability of cover, both instream and bank, and average depth. I believe that these variables capture the habitat needs of this size class as they make the transition from juvenile to adult. Admittedly, this was the most difficult size class to determine habitat suitability criteria for, since the behavioral patterns of these fish may have components that resemble both juveniles and large adult brook trout.

Brook trout population sampling - Methods used for brook trout population sampling are described in the methods section of Chapter 1 . The quantification of brook trout residency and growth rates through mark-recapture data were the focus of this portion of the study. I also determined the size structure of brook trout populations within my study sites, in order to quantify size structured fluctuations in the population.

The mark-recapture study was performed by giving captured individuals a unique identification mark, using colored elastomer dye. Marks were placed in the caudal and/or anal fin and the use of multiple colors and fin locations allowed for the identification of individuals upon recapture during future sampling efforts. Brook trout shorter than $50 \mathrm{~mm}$ standard length were marked using a clip to the upper or lower caudal fin. All fish were returned to their approximate location of capture.

Population size structure was determined by separating brook trout into three size class based on standard length from the pooled results of all eleven sampling sites (see Table 2 and Figure 4, Chapter 1). Juveniles and small adults were easily separated into size classes. The remaining individuals in the population were categorized as large adults. Spring 2001 recaptures were grouped by their size class at the time of marking during the previous fall. 
Growth Rates - Due to the relatively short intervals between resampling events ( $<8$ months), I expressed growth rates from recaptured and identified individuals as instantaneous growth rate (percentage) per day $\left(\% \mathrm{~g} \mathrm{~g}^{-1}\right.$ day $\left.^{-1}\right): \mathrm{G}_{\mathrm{w}}=100\left(\ln \mathrm{W}_{\mathrm{t}}-\ln \mathrm{W}_{\mathrm{o}}\right) /\left(\mathrm{t}_{\mathrm{n}}-\mathrm{t}_{\mathrm{o}}\right)$ where Wo is the wet weight on day $t_{o}$ and $W_{t}$ is the wet weight on day $t_{n}$ (Jensen 1990). Growth rates were calculated for each size class, season, and study site. Growth rates of fin clipped juveniles were quantified by comparing the wet weight to the mean wet weight of all juveniles captured in that site the previous season. Annual growth rates were determined for each size class from pooled data for each study site.

Residency rates - Residency rates were also quantified for each size class, season, and site from identified, recaptured individuals. Residency was defined as the proportion of previously marked brook trout from a sampling site that were recovered in the same sampling site the following season. Individuals that were marked in a sampling site and were recaptured in the same site, but the recapture did not occur during the following seasons sampling (i.e. marked in spring recaptured in fall) were not considered residents. I felt this was necessary since I could not know whether these fish were simply residents that I failed to capture during the previous seasons sampling or if they were fish that had moved out of the site and returned prior to my sampling. Operating under the assumption that uncaptured, marked individuals were moving out of study sites, rather than simply not being caught in our sampling, results in conservative estimates for residency rates. The accuracy of these estimates should be high since population sampling methods and effort were consistent among study sites and seasons and probability of captures were consistent throughout the study.

Fluctuations in population size structure- Brook trout population size structure was determined for each study site, and in each season of the study, by separating captured brook trout into three 
size classes based on standard length (see Table 2 and Figure 4, Chapter 1). The number of individuals caught in each size class was transformed into a percentage by dividing the number of brook trout caught in each size class by the total number of brook trout captured. These results were used to quantify the spatial and temporal average relative fluctuation (A.R.F.) of brook trout size structure during the study. Average relative fluctuation was calculated as: A.R.F = $\left(\%_{\max }-\%_{\min }\right) / \%_{\text {avg }} \times 100$. Platts and Nelson (1988) used the average relative fluctuation model as a component of analysis to evaluate the fluctuations of trout populations in the intermountain region of the western United States. My use of this model should provide insight into the spatial and temporal stability of brook trout populations in Second Fork. Fluctuations can then be related to the habitat characteristics of study sites, and used to identify areas of the watershed that are important to each size class of brook trout.

Statistical analysis - I used one-way analysis of variance (ANOVA) with a Tukey's multiple comparison test to detect differences of growth and residency rates among size class of brook trout, among seasons, and among study sites with different levels of habitat suitability (i.e. high, intermediate, and low). I also used ranked correlation analysis to determine significant relationships between growth, residency, population stability and specific stream habitat variables that made up components of the habitat suitability criteria (i.e. \% spawning, stream alkalinity, water depth, \% cover).

\section{Results}

\section{Habitat suitability}

I generated relative habitat suitability criteria based on the relative availability of complementary habitats within my study sites (Table 2). Based on these relative rankings I established three levels of suitability for three size classes of brook trout within each study site 
(Table 3). The levels of suitability were used as a basis for comparison of residency and growth rates for three age-classes of brook trout in Second Fork. Although some sites ranked high (site 10) or low ( site 1) for all three year classes, most sites varied in the size class specific habitat suitability (Table 3).

Brook trout growth

Growth rates of brook trout in Second Fork were determined by size and season. Brook trout annual growth rates were found to be size-dependent with significant difference among size classes (F-value 31.23, df=2, $<<0.001$, Table 4). Specifically, I found annual growth rates to be significantly higher for juveniles than either small or large adults. Seasonal growth rates were significantly highest for juvenile, small adult and for the sample brook trout population as a whole from spring to summer (Table 5). Large adult brook trout growth was lowest from summer to fall with no significant differences in mean growth rates from spring to summer and from fall to spring ( F-value 7.02, $\mathrm{df}=2, \mathrm{p}<0.002$, Table 5).

Annual growth rates for small adults were found to be higher in sites with a medium suitability ranking than for sites with a high suitability (F-value 4.11, $\mathrm{df}=2, \mathrm{p}=0.02$, Table 6). Growth was not found to be significantly different among sites of different suitability levels for large adults and juveniles.

Ranked correlation analysis provided additional information about the relationship between brook trout growth parameters and stream habitat variables. I found significant positive ranked correlations between juvenile maximum $(n=11, p=0.01$, Table 7$)$ and minimum growth rates $(n=11, p=0.001$, Table 7) and distance from the mouth of Second Fork (i.e. in headwaters sites). Furthermore, there was a positive correlation between ranks of juvenile maximum growth and the availability of stream margin $(n=11, p=0.002$, Table 7$)$. I found negative ranked 
correlations between mean $(n=11, p=0.01$, Table 7) and minimum $(n=11, p=0.01$, Table 7) growth rates and the availability of spawning habitat for small adult brook trout.

\section{Brook trout residency}

I observed significant differences in residency rates of brook trout among size class and study sites based on habitat suitability criteria (Tables 8 and 9). Mean residency rates were found to be significantly highest for small adults ( $F$-value $9.54, \mathrm{df}=2, \mathrm{p}=0.002$, Table 8 ). Mean residency rates were not significantly different between juvenile and large adult brook trout. Analysis failed to identify significant seasonal patterns to brook trout residency rates, due to the use of a relatively conservative multiple comparison test. Seasonal residency rates for small adults were significantly different ( $F$-value $3.74, d f=2, p=0.04$ ). The seasonal trend to residency rates is that residency tends to be highest from spring to summer for each size class.

Large adult (F-value 3.23, $\mathrm{df}=2, \mathrm{p}=0.05$, Table 9$)$ and juvenile $(\mathrm{F}$-value $4.18, \mathrm{df}=2$, $\mathrm{p}=0.02$, Table 9) residency rates were significantly higher in study sites with high suitability than in sites with low suitability. The same trend was found when all size classes were included in the analysis (F-value 4.18, $\mathrm{df}=2, \mathrm{p}$-value $=0.02$, Table 9). Small adult brook trout were found to have significantly higher residency rates than large adults in study sites with low habitat suitability (Fvalue $7.13, \mathrm{df}=2, \mathrm{p}=0.004$, Table 10 ). Small adult brook trout were found to have significantly higher residency rates than juveniles and large adults in study sites with medium suitability (Fvalue $6.42, \mathrm{df}=2, \mathrm{p}=0.004$, Table 10 ). No significant differences were found between residency rates for each size class in study sites with high suitability.

Ranked correlation analysis allowed me to determine specifically which habitat parameters were influencing brook trout residency patterns. Analysis resulted in a significant positive relationship between habitat suitability scores and residency rates for juvenile ( $\mathrm{n}=11$, 
$\mathrm{p}=0.055$, Table 7) and large adult brook trout $(\mathrm{n}=11, \mathrm{p}=0.055$, Table 7). A significant positive ranked correlation was found between juvenile residency rates and the availability of undercut banks ( $\mathrm{n}=11, \mathrm{p}=0.04$, Table 7$)$. Large adult brook trout residency rates were positively correlated with the maximum depth $(n=11, p=0.05$, Table 7$)$ and availability of instream cover $(n=11$, $\mathrm{p}=0.03$, Table 7) in study sites. I found size dependent spatial trends for mean residency rates of brook trout in Second Fork (Figure 2). Large adult residency rates tended to be highest closest to the mouth of Second Fork, with the lowest residency rates found in the headwater tributaries. The trend was opposite for juveniles, with higher residency rates in the headwaters of Second Fork, with highest residency rates occurring in the tributaries. Small adult brook trout residency rates tended to be relatively high and spatially stable (Figure 2).

\section{Population size structure and mean relative fluctuations}

I found the population size structure of brook trout and the mean relative fluctuations of populations to be both spatially and temporally variable. The population size structure of brook trout in the Second Fork watershed is shown in Figure 3. The seasonal size structure of brook trout populations in Second Fork is shown in Figure 4. Variation in relative abundance was smallest in Spring 2000 and most variable in Fall 2000 when the percentage of juveniles and small adults increased and the percentage of large adults decreased within the study sites. A comparison of relative abundance between Spring 2000 and Spring 2001 shows an increase in spatial variability due primarily to low juvenile and high small adult relative abundances in the headwaters of Second Fork.

Relative abundances for juvenile, small adult, and large adult brook trout are shown in Figure 4. Juvenile relative abundance increased from Spring 2000 to Fall 2000. Reductions in juvenile abundance in the headwaters of Second Fork during Spring 2001 caused the greatest 
fluctuation in the seasonal trends. Small adult seasonal relative abundances were the most stable of the three size classes, with the greatest fluctuations occurring in Spring 2001 when relative abundance in the headwaters increased to its highest level. This fluctuation may have been in response to reduced numbers of juveniles in these locations. Relative abundance of large adults was greatest near the mouth of Second Fork and in the headwaters. Relative abundances were lowest in Fall 2000 and greatest in Spring 2000 and Spring 2001. Spatial and temporal trends of average relative fluctuations in populations of brook trout in Second Fork show that juvenile, and large adult populations, are most variable in the headwaters of Second Fork (Figure 5). Small adult populations were spatially stable throughout the study (Figure 5). Seasonal fluctuations in large adult populations were greatest in the fall and generally smallest during spring. Juvenile and small adult brook trout populations were relatively stable throughout each season of the study, until Spring 2001 when fluctuations for each size class increased greatly.

\section{Discussion}

\section{Habitat complementation and brook trout population dynamics}

The availability of complementary habitats had the strongest effect on patterns of residency for brook trout in Second Fork. Both large adult and juvenile brook trout showed significantly higher residency rates in sites with high suitability rankings. The failure to detect differences in residency rates of small adult brook trout may be due to a high degree of flexibility in habitat selection due to their intermediate size. This idea is supported by the consistent spatial trend in small adult residencies, while large adults and juvenile exhibit higher rates of residency in either the headwaters or in the lower reaches of Second Fork. Interestingly, the two habitat components that seem to be driving residency rates for juveniles and large adults are water depth and availability of cover. Large adult residencies are best explained by maximum depth and 
availability of instream cover. This suggests that large adults are not selecting habitat based on the availability of the nearest spawning habitat. It is also important to remember that apparent survival is a component of residency rates, and is probably most important in understanding the residency rates of juvenile brook trout. The availability of undercut banks may provide the cover necessary to avoid predators in the headwater streams that they inhabit. Undercut banks may also provide refugia from high flow events that may displace juveniles from "home" areas and reduce residency estimates.

The only significant relationship between complementary habitats and brook trout growth was found for small adults. This may be due to overlap of habitat criteria between small and large adults. The overlap in sites with high suitability rankings (Sites 3 and 10) may indicate that the high residency rates of large adults in sites with high suitability for small adults (Table 9) may be altering their habitat selection and growth patterns. Growth rates may also be uniformly low due to the low productivity and the relatively high elevation of the watershed (Whitworth and Strange 1983, Konopacky and Estes 1986).

\section{Brook trout growth and population fluctuations}

The results of my data show that brook trout growth rates are significantly highest from spring to summer for each size class. Also, population stability tended to be greatest in the spring. These results suggest that habitat selection, probably driven by foraging site quality, is homogenous throughout the watershed. This spatial pattern is best explained by a even distribution and relatively high seasonal abundance of macroinvertebrates in streams during spring (Vannote 1980, Bopp 2002). Brook trout populations in the Second Fork watershed grew at a slower rate and experienced larger spatial fluctuations, especially large adults, in summer to fall. Summer fluctuations in large adult populations were possibly driven by reductions in foraging site quality 
due to the seasonal reduction of macroinvertebrate abundance in these low productivity streams. Large adult populations tended to remain relatively stable in the lower reaches of the watershed where the canopy is relatively open and invertebrate populations may also be temporally stable. The low growth and stability of large adult brook trout in fall is probably due to low stream productivity and a shift from selecting habitat based on foraging quality to suitability for spawning..

\section{Spatial trends in brook trout residency rates}

Brook trout residency rates were highest from spring to summer, again supported by the idea of seasonal fluctuations in foraging site quality. The spatial patterns of residency rates for the three size classes of brook trout are extremely interesting and show the importance of understanding the population regulating components that comprise residency estimates. Residency rates represent a combination of mobility potential and apparent survivorship (i.e. size dependent threats to predation). My data shows these trends with dramatic clarity. Juvenile residency rates are highest in the headwaters, where they are born, due to low mobility and a relatively low threat of predation due to a simple fish community structure (see Table 4, Chapter 1) and a relative lack of large brook trout. Individuals that are displaced from the headwaters likely succumb to predation, driving residency estimates down as they move downstream. Large adults may be highly mobile and have low risk of predation, resulting in a residency estimate determined largely by movement patterns. I found positive correlation between large adult residency rates and the availability of instream cover and maximum depth within the study sites. Both of these habitat parameters are most abundant in the relatively high gradient middle section of the watershed (Sites 3 and 4). This relationship further suggests that foraging site quality and the availability of winter habitat, in the form of deep pools, is influencing residency patterns of 
large adult brook trout. Harvey (1998) found that residency rates of coastal cutthroat trout were highest in streams with high availability of deep pools formed by large woody debris (LWD). The low residency rates of large adults in the headwaters suggest that individuals may be using this section of watershed predominantly for spawning and populations in the headwaters may be ephemeral in nature.

\section{Seasonal population fluctuations}

Seasonal population fluctuation data help to support the seasonal and spatial variation in brook trout growth and residency. The striking difference in the pattern of population fluctuations is the relatively high degree of fluctuation in Spring 2001 when compared to Spring 2000. The homogenous distribution of foraging site quality during this season should result in spatially stable populations. The instability of Spring 2001 is almost certainly caused from the reproductive failure that occurred in Site 9 due to a severe acidic episode that occurred in mid February. Populations in nearby sites with higher buffering capacity remained relatively stable

(Figure 4 and Figure 5). The dramatic difference in population stability between Spring 2000 and Spring 2001 suggests that these events may be stochastic in nature rather than annual events due to snowmelt.

\section{Management Implications}

This study illustrates the importance of the concept of habitat complementation to the management of salmonid populations. These populations rely on different areas of the watershed to complete different components of their annual life cycle. The protection of complementary habitats and the maintenance of connectivity between these habitats should allow populations to persist, or even grow by ensuring that individuals will have areas in which they can successfully reproduce, forage, and escape from predators or environmental extremes. To accomplish this 
managers must look at the scale in which the life history patterns occur and manage habitats at that scale. Brook trout in Second Fork exhibit life history patterns that encompass the entire watershed and should be managed at that scale. The headwater streams are important to reproduction and also serve as nursery habitat for juveniles. The lower reaches serve as important foraging and winter habitats for large adults. Degradation of habitat quality to either of these areas would have dramatic consequences to the local population by interrupting the annual life cycle.

The results of my study show that there were dramatic differences in the population dynamics of brook trout in Second Fork. It would have been truly impossible to capture these differences with a study design that did not include a large number of study sites and seasonal population sampling. This fact supports the need for long term studies conducted over large spatial scales (i.e. a minimum of at the watershed scale). Small-scale studies may provide limited amount of population information that may be misleading if not compared to seasonal data. An example of this is the difference in average relative population fluctuations between the two spring samples of this study. If I had sampled only during Spring 2000, I may have concluded that seasonal variation in foraging site quality is driving fluctuations in the population size structure. I may also have concluded that while this watershed has relatively low productivity due to low stream alkalinities, the buffering capacity is sufficient to prevent large fluctuations in juvenile numbers due to spatial variation in reproductive success. This conclusion would have been false and misleading. The same result could have occurred if I had decided to sample brook trout populations in only a small number of locations, possibly missing the important dynamics occurring in the headwaters of Second Fork. 
The effects of low alkalinity levels in the headwaters of Second Fork obviously had dramatic effects on juvenile brook trout populations and every effort should be made to mitigate these effects (see Chapter 1). The overall low productivity of the watershed may be directly impacting large adults by reducing foraging site quality in late summer. Bopp (2002) showed that macroinvertebrate abundance during late summer in Second Fork is greatest in areas with open canopy. I suggest that by using a low impact method of tree removal, the canopy could be opened, further improving foraging site quality in late summer. Hetrick et al. (1998) showed that opening the canopy in streams of southeast Alaska had a positive effect on the biomass of stream invertebrates. Further benefits could be realized from this cutting operation, if logs were placed in Second Fork, possibly increasing the availability and quality of deepwater pools that could be used by brook trout as winter habitat. 


\section{References}

Baker, E.A., and T.G. Coon. 1997. Development and evaluation of alternative habitat suitability criteria for brook trout. Transactions of the American Fisheries Society 126:65-76.

Beard, T.D., and R.F. Carline. 1991. Influence of spawning and other stream habitat features on spatial variability of wild brown trout. Transactions of the American Fisheries Society 120:711722.

Bopp, J. 2002. The combined effects of water chemistry, canopy cover, and basin area on benthic macroinvertebrates along a central Appalachian stream continuum. Master's Thesis. West Virginia University.

Carline, R.F., D.R. Dewalle, W.E. Sharpe, B.A. Dempsey, C.J. Gagen, and B. Swistock. 1992. Water chemistry and fish community responses to episodic stream acidification in Pennsylvania, USA. Environmental Pollution 78:45-48.

Cunjak, R.A. 1996. Winter habitat of selected stream fishes and potential impacts from land-use activity. Canadian Journal of Fisheries and Aquatic Sciences 53(Suppl. 1):267-282.

Curry, R.A., D.L.G. Noakes, and G.E. Morgan. 1995. Groundwater and the incubation and emergence of brook trout (Salvelinus fontinalis). Canadian Journal of Fisheries and Aquatic Sciences 52:1741-1749.

Dowdy, S., and S. Wearden. 1991. Statistics for Research. $2^{\text {nd }}$ edition. John Wiley and Sons. N.Y.

Elliott, J.M. 2000. Pools as refugia for brown trout during two summer droughts: trout responses to thermal and oxygen stress. Journal of Fish Biology 56:938-948.

Fausch, K.D. 1984. Profitable stream positions for salmonids: relating specific growth rate to net energy gain. Canadian Journal of Zoology 62:441-451.

Harvey, B.C. 1998. Influence of large woody debris on retention, immigration, and growth of coastal cutthroat (Oncorhynchus clarki clarki) in stream pools. Canadian Journal of Fisheries and Aquatic Sciences 55:1902-1908.

Hayes, D.B., C. P. Ferreri, W.W. Taylor. 1996. Linking fish habitat to their population dynamics. Canadian Journal of Fisheries and Aquatic Sciences 53(Suppl 1.):383-390.

Heifetz, J., M.L. Murphy, and K.V. Koski. 1986. Effects of logging on winter habitat of juvenile salmonids in Alaskan streams. North American Journal of Fisheries Management 6:52-58. 
Hetrick, N.J., M.A. Brusven, T.C. Bjornn, R.M. Keith, and W.R. Meehan. 1998. Effects of canopy removal on invertebrates and diet of juvenile coho salmon in a small stream in southeast Alaska. Transactions of the American Fisheries Society 127:876-888.

Hughes, N.F. and L.M. Dill. 1990. Position choice by drift-feeding salmonids: model and test for Arctic grayling (Thymallus arcticus) in subarctic mountain streams, interior Alaska. Canadian Journal of Fisheries and Aquatic Sciences 47:2039-2048.

Hughes, N.F. 1992. Selection of positions by drift-feeding salmonids in dominance hierarchies: model and test for arctic grayling (Thymallus arcticus) in subarctic mountain streams, interior Alaska. Canadian Journal of Fisheries and Aquatic Sciences 49:1999-2008.

Hughes, N.F. 1998. A model of habitat selection by drift-feeding stream salmonids at different scales. Ecology 79(1):281-294.

Jensen, A.J. 1990. Growth of young migratory brown trout Salmo trutta correlated with water temperature in Norwegian rivers. Journal of Animal Ecology 59:603-614.

Johnson, S.L., F.J. Rahel, and W.A. Hubert. 1992. Factors influencing the size structure of brook trout populations in beaver ponds in Wyoming. North American Journal of Fisheries Management 12:118-124.

Josephson, D.C., and W.D. Youngs. 1996. Association between emigration and age structure in populations of brook trout (Salvelinus fontinalis) in Adirondack lakes. Canadian Journal of Fisheries and Aquatic Sciences 53:534-541.

Konopacky, R.C., and R.D. Estes. 1986. Age and growth of brook trout in southern Appalachian streams. Proceedings of the Annual Conference of Southeastern Fish and Wildlife agencies 40:227-236.

Krueger, C.C., and T.F. Waters. 1983. Annual production of macroinvertebrates in three streams of different water quality. Ecology 64(4):840-850.

Kwak, T.J., and T.F. Waters. 1997. Trout production dynamics and water quality in Minnesota streams. Transactions of the American Fisheries Society 126:35-48.

McLaughlin, R.L., J.W.A. Grant, and D.L. Kramer. 1994. Foraging movements in relation to morphology, water-column use, and diet for recently emerged brook trout (Salvelinus fontinalis) in still-water pools. Canadian Journal of Fisheries and Aquatic Sciences 51:268-279.

Moore, K.M.S. and S.V. Gregory. 1988. Summer habitat utilization and ecology of cutthroat trout fry (Salmo clarki) in Cascade Mountain streams. Canadian Journal of Fisheries and Aquatic Sciences 45:1921-1930.

Platts, W.S., and R.L. Nelson. 1988. Fluctuations in trout populations and their implications for land-use evaluations. North American Journal of Fisheries Management 8:333-345. 
Pulliam, H.R. 1988. Sources, sinks, and population regulation. The American Naturalist 132:652-661.

Riley, S.C., and K.D. Fausch, C. Gowan. 1992. Movement of brook trout (Salvelinus fontinalis) in four small subalpine streams in northern Colorado. Ecology of Freshwater Fish 1:112-122.

Riley, S.C., and K.D. Fausch. 1995. Trout population responses to habitat enhancement in six northern Colorado streams. Canadian Journal of Fisheries and Aquatic Sciences 52:34-53.

Schlosser, I.J. 1985. Flow regime, juvenile abundance, and the assemblage structure of stream fishes. Ecology 66(5):1484-1490.

Schlosser, I.J. 1988. Predation risk and habitat use by two size classes of a stream cyprinid: Experimental test of a hypothesis. Oikos 52:36-40.

Schlosser, I.J. 1991. Stream fish ecology: a landscape perspective. Bioscience 41:704-712.

Schlosser, I.J. 1995. Critical landscape attributes that influence fish population dynamics in headwater streams. Hydrobiologia 303:71-81.

Schlosser, I.J., and P.L. Angermeier. 1995. Spatial variation in demographic processes of lotic fishes: Conceptual models, empirical evidence, and implications for conservation. American Fisheries Society Symposium 17:392-401.

Schlosser, I.J. 1998. Fish recruitment, dispersal, and trophic interactions in a heterogeneous lotic environment. Oecologia 113:260-268.

Solazzi, M.F., T.E. Nickelson, S.L. Johnson, and J.D. Rodgers. 2000. Effects of increasing winter rearing habitat on abundance of salmonids in two coastal Oregon streams. Canadian Journal of Fisheries and Aquatic Sciences 57:906-914.

Vannote, R.L., G.W. Minshall, K.W. Cummins, J.R. Sedell, C.E. Cushing. 1980. The river continuum concept. Canadian Journal of Fisheries and Aquatic Sciences 37:130-137.

Whitworth, W.E., and R.J. Strange. 1983. Growth and production of sympatric brook and rainbow trout in an Appalachian stream. Transactions of the American Fisheries Society 112:469-475.

Witzel, L.D. and H.R. MacCrimmon. 1983. Redd-site selection by brook trout and brown trout in southwestern Ontario streams. Transactions of the American Fisheries Society 112:760-771.

Zar, J.H. 1999. Biostatistical analysis. $4^{\text {th }}$ edition. Prentice-Hall, Upper Saddle River, New Jersey. 
Table 1. Stream habitat parameters used to rank suitability of study sites for brook trout populations within the Second Fork watershed.

\begin{tabular}{ll}
\hline Size class & Stream habitat parameters \\
\hline juvenile & $\begin{array}{l}\text { stream alkalinity } \\
\text { spawning habitat } \\
\text { undercut banks } \\
\text { stream margin }\end{array}$ \\
\hline small adult & $\begin{array}{l}\text { stream alkalinity } \\
\text { spawning habitat } \\
\text { total cover } \\
\text { average depth }\end{array}$ \\
\hline large adult & $\begin{array}{l}\text { stream alkalinity } \\
\text { spawning habitat } \\
\text { instream cover } \\
\text { maximum depth }\end{array}$ \\
\hline
\end{tabular}


Table 2. Physical description of study sites within the Second Fork watershed. Relative values of habitat parameters were used to determine relative habitat suitability of study sites for three size classes of brook trout. Relative rank of study sites for each habitat parameter is shown in parentheses.

\begin{tabular}{c|cc|cc|cc|cc}
\hline \multicolumn{3}{c}{ Large adults } & \multicolumn{2}{c}{ Small adults } & \multicolumn{2}{c}{ Juveniles } & \multicolumn{2}{c}{ All size classes } \\
\hline Site & $\begin{array}{l}\text { max. depth } \\
(\mathrm{cm})\end{array}$ & $\begin{array}{l}\text { \% instream } \\
\text { cover }\end{array}$ & $\begin{array}{l}\text { \% bank } \\
\text { cover }\end{array}$ & \% margin & $\begin{array}{l}\text { average } \\
\text { depth(cm) }\end{array}$ & $\begin{array}{l}\text { \%total } \\
\text { cover }\end{array}$ & \%spawn alkalinity \\
\hline 1 & $58(7)$ & $28(9)$ & $13(3)$ & $14(10)$ & $30(6)$ & $40(10)$ & $4(11)$ & $8.9(6)$ \\
2 & $60(6)$ & $48(4)$ & $8(7)$ & $23(3)$ & $33(5)$ & $55(2)$ & $15(5)$ & $8.4(7)$ \\
3 & $88(1)$ & $65(1)$ & $8(7)$ & $10(11)$ & $40(1)$ & $73(1)$ & $15(5)$ & $6.6(9)$ \\
4 & $85(2)$ & $37(7)$ & $7(9)$ & $22(4)$ & $40(1)$ & $44(8)$ & $13(9)$ & $10.1(4)$ \\
5 & $63(5)$ & $52(2)$ & $13(3)$ & $20(5)$ & $38(3)$ & $53(4)$ & $10(10)$ & $9.7(5)$ \\
6 & $48(9)$ & $18(11)$ & $23(2)$ & $20(5)$ & $20(11)$ & $40(10)$ & $15(5)$ & $17.2(2)$ \\
7 & $40(11)$ & $50(3)$ & $5(10)$ & $42(1)$ & $25(9)$ & $55(5)$ & $15(5)$ & $7.6(8)$ \\
8 & $48(9)$ & $40(5)$ & $5(10)$ & $15(9)$ & $30(6)$ & $45(7)$ & $18(4)$ & $16.2(3)$ \\
9 & $68(4)$ & $30(8)$ & $13(3)$ & $20(5)$ & $28(8)$ & $43(8)$ & $20(2)$ & $5.3(10)$ \\
10 & $50(8)$ & $23(10)$ & $28(1)$ & $40(2)$ & $25(10)$ & $50(6)$ & $45(1)$ & $22.4(1)$ \\
11 & $84(3)$ & $40(5)$ & $12(6)$ & $20(5)$ & $39(3)$ & $52(10)$ & $20(2)$ & $4.2(11)$ \\
\hline
\end{tabular}


Table 3. Habitat suitability rankings of eleven study sites within the Second Fork watershed for three size classes of brook trout.

\begin{tabular}{llc}
\hline Size class & Suitability ranking & Study sites \\
\hline juvenile & high & $6,9,10$ \\
& medium & $2,5,7,8,11$ \\
& low & $1,4,3$ \\
\hline small adult & high & $2,3,10$ \\
& medium & $4,5,7,8,11$ \\
& low & $1,6,9$ \\
\hline large adult & high & $3,10,11$ \\
& medium & $2,4,5,8,9$ \\
& low & $1,6,7$ \\
\hline
\end{tabular}


Table 4. Annual growth rates among three size classes of brook trout within the Second Fork watershed. Results are from pooled seasonal data for each size class. Means with different letters are significantly different from one another.

\begin{tabular}{lcc}
\hline Size class & $\mathrm{n}$ & Mean growth $\left(\%\right.$ day $\left.^{-1}\right)$ \\
\hline juvenile & 108 & $0.75^{\mathrm{A}}$ \\
small adult & 141 & $0.30^{\mathrm{B}}$ \\
large adult & 51 & $0.11^{\mathrm{B}}$ \\
\hline
\end{tabular}


Table 5. Mean seasonal growth rates of brook trout within the Second Fork watershed. Means within each size class with different letters are significantly different from another.

\begin{tabular}{|c|c|c|}
\hline Size class & Season & Mean growth $\left(\% \mathrm{~d}^{-1}\right)$ \\
\hline \multirow[t]{3}{*}{ juvenile } & summer & $1.64^{\mathrm{A}}$ \\
\hline & fall & $0.39^{\mathrm{B}}$ \\
\hline & winter/spring & $0.34^{\mathrm{B}}$ \\
\hline \multirow[t]{3}{*}{ small adult } & summer & $0.41^{\mathrm{A}}$ \\
\hline & fall & $0.24^{\mathrm{B}}$ \\
\hline & winter/spring & $0.22^{\mathrm{B}}$ \\
\hline \multirow[t]{3}{*}{ large adult } & summer & $0.20^{\mathrm{A}}$ \\
\hline & fall & $-0.06^{\mathrm{B}}$ \\
\hline & winter/spring & $0.20^{\mathrm{A}}$ \\
\hline \multirow[t]{3}{*}{ all classes } & summer & $0.70^{\mathrm{A}}$ \\
\hline & fall & $0.21^{\mathrm{B}}$ \\
\hline & winter/spring & $0.29^{\mathrm{B}}$ \\
\hline
\end{tabular}


Table 6. Mean growth rates among sites based on habitat suitability. Means within each size class with different letters are significantly different from one another.

\begin{tabular}{lll}
\hline Size class & Habitat suitability(rank) & Mean growth $\left(\% \mathrm{~d}^{-1}\right)$ \\
\hline juvenile & high & $0.81^{\mathrm{A}}$ \\
& medium & $0.80^{\mathrm{A}}$ \\
& low & $0.42^{\mathrm{A}}$ \\
small adult & high & $0.22^{\mathrm{B}}$ \\
& medium & $0.38^{\mathrm{A}}$ \\
& low & $0.30^{\mathrm{AB}}$ \\
\hline large adult & high & $0.11^{\mathrm{A}}$ \\
& medium & $0.08^{\mathrm{A}}$ \\
& low & $0.32^{\mathrm{A}}$ \\
\hline all classes & hedium & $0.49^{\mathrm{A}}$ \\
& low & $0.41^{\mathrm{A}}$ \\
& & $0.34^{\mathrm{A}}$ \\
\hline
\end{tabular}


Table 7. Results of ranked correlation analysis between brook trout demographic and stream habitat parameters within study sites. Stream habitat variables with a (-) indicate a negative relationship.

\begin{tabular}{llll}
\hline Size-class & Dependent variable & Independent variable & p-value \\
\hline juvenile & maximum growth & distance from mouth & 0.03 \\
& residency & suitability score & 0.055 \\
& maximum growth & \% stream margin & 0.002 \\
small adult & mesidency & \% bankcover & 0.04 \\
& minimum growth & \% spawning habitat $(-)$ & 0.01 \\
large adult & residency & \% spawning habitat $(-)$ & 0.01 \\
& residency & \% instream cover & 0.03 \\
& residency & maximum depth & 0.05 \\
& avg. relative fluctuation & maximum depth $(-)$ & 0.055 \\
& avg. relative fluctuation & distance from mouth & 0.07 \\
& & & 0.05
\end{tabular}


Table 8. Variation in residency rates among three size classes of brook trout within the Second Fork watershed. Residency rate is defined as the $\%$ of the population remaining within the same study site from one sampling event to the next. Means with different letters are significantly different from one another.

\begin{tabular}{lcc}
\hline Size class & $\mathrm{n}$ & Mean residency rate(\%) \\
\hline juvenile & 108 & $23^{\mathrm{B}}$ \\
small adult & 141 & $33^{\mathrm{A}}$ \\
large adult & 51 & $18^{\mathrm{B}}$ \\
\hline
\end{tabular}


Table 9. Results of analysis of variance for mean residency rates among sites based on habitat suitability. Means within each size class with different letters are significantly different from another.

\begin{tabular}{|c|c|c|}
\hline size class & habitat suitability(rank) & mean residency $(\%)$ \\
\hline \multirow[t]{3}{*}{ juvenile } & high & $36^{\mathrm{A}}$ \\
\hline & medium & $18^{\mathrm{AB}}$ \\
\hline & low & $17^{\mathrm{B}}$ \\
\hline \multirow[t]{3}{*}{ small adult } & high & $30^{\mathrm{A}}$ \\
\hline & medium & $35^{\mathrm{A}}$ \\
\hline & low & $32^{\mathrm{A}}$ \\
\hline \multirow[t]{3}{*}{ large adult } & high & $27^{\mathrm{A}}$ \\
\hline & medium & $19^{\mathrm{AB}}$ \\
\hline & low & $8^{\mathrm{B}}$ \\
\hline \multirow[t]{3}{*}{ all classes } & high & $31^{\mathrm{A}}$ \\
\hline & medium & $24^{\mathrm{B}}$ \\
\hline & low & $19^{\mathrm{B}}$ \\
\hline
\end{tabular}


Table 10. Comparison of residency rates among three size classes of brook trout for three levels of habitat suitability within the Second Fork watershed. Means within each suitability class with different letters are significantly different from another.

\begin{tabular}{lcc}
\hline Size class & Suitability & Mean residency rate(\%) \\
\hline juvenile & low & $17^{\mathrm{AB}}$ \\
small adult & low & $8^{\mathrm{A}}$ \\
large adult & low & $18^{\mathrm{B}}$ \\
juvenile & medium & $35^{\mathrm{A}}$ \\
small adult & medium & $19^{\mathrm{B}}$ \\
large adult & medium & $36^{\mathrm{A}}$ \\
\hline juvenile & high & $30^{\mathrm{A}}$ \\
small adult & high & $27^{\mathrm{A}}$ \\
large adult & high & \\
\hline
\end{tabular}


Table 11. Population size structure and average relative fluctuation (ARF) of brook trout within the Second Fork watershed. ARF describes the magnitude of change in the relative abundance of each size class to the mean value of the relative abundance.

\begin{tabular}{|c|c|c|c|c|c|c|c|}
\hline Season & Site & Juveniles(\%) & A.R.F(\%) & Sm. adults(\%) & A.R.F.(\%) & Lg. adult (\%) & A.R.F.(\%) \\
\hline Spring(2000) & 1 & 42 & 85 & 31 & 55 & 28 & 97 \\
\hline Summer & 1 & 41 & & 44 & & 16 & \\
\hline Fall & 1 & 58 & & 25 & & 17 & \\
\hline Spring(2001) & 1 & 23 & & 37 & & 40 & \\
\hline Spring(2000) & 2 & 36 & 58 & 36 & 52 & 28 & 82 \\
\hline Summer & 2 & 27 & & 50 & & 23 & \\
\hline Fall & 2 & 50 & & 40 & & 10 & \\
\hline Spring(2001) & 2 & 43 & & 30 & & 27 & \\
\hline Spring(2000) & 3 & 29 & 83 & 35 & 41 & 35 & 45 \\
\hline Summer & 3 & 18 & & 43 & & 39 & \\
\hline Fall & 3 & 28 & & 47 & & 25 & \\
\hline Spring(2001) & 3 & 42 & & 31 & & 27 & \\
\hline Spring(2000) & 4 & 19 & 66 & 41 & 51 & 41 & 96 \\
\hline Summer & 4 & 30 & & 27 & & 43 & \\
\hline Fall & 4 & 39 & & 46 & & 14 & \\
\hline Spring(2001) & 4 & 40 & & 38 & & 22 & \\
\hline Spring(2000) & 5 & 20 & 67 & 44 & 57 & 36 & 136 \\
\hline Summer & 5 & 40 & & 37 & & 23 & \\
\hline Fall & 5 & 42 & & 53 & & 5 & \\
\hline Spring(2001) & 5 & 29 & & 29 & & 41 & \\
\hline Spring(2000) & 6 & 40 & 43 & 47 & 60 & 14 & 117 \\
\hline Summer & 6 & 56 & & 41 & & 2 & \\
\hline Fall & 6 & 47 & & 42 & & 11 & \\
\hline Spring(2001) & 6 & 62 & & 24 & & 15 & \\
\hline Spring(2000) & 7 & 31 & 133 & 51 & 59 & 17 & 204 \\
\hline Summer & 7 & 55 & & 38 & & 7 & \\
\hline Fall & 7 & 60 & & 40 & & 0 & \\
\hline Spring(2001) & 7 & 8 & & 67 & & 25 & \\
\hline Spring(2000) & 8 & 50 & 76 & 25 & 91 & 25 & 117 \\
\hline Summer & 8 & 32 & & 50 & & 18 & \\
\hline Fall & 8 & 56 & & 32 & & 12 & \\
\hline Spring(2001) & 8 & 72 & & 21 & & 7 & \\
\hline Spring(2000) & 9 & 39 & 181 & 30 & 65 & 30 & 203 \\
\hline Summer & 9 & 46 & & 42 & & 13 & \\
\hline Fall & 9 & 70 & & 30 & & 0 & \\
\hline Spring(2001) & 9 & 0 & & 56 & & 44 & \\
\hline Spring(2000) & 10 & 40 & 56 & 48 & 50 & 13 & 161 \\
\hline Summer & 10 & 60 & & 29 & & 11 & \\
\hline Fall & 10 & 70 & & 30 & & 0 & \\
\hline Spring(2001) & 10 & 48 & & 44 & & 8 & \\
\hline Spring(2000) & 11 & 30 & 37 & 37 & 62 & 33 & 83 \\
\hline Summer & 11 & 42 & & 32 & & 26 & \\
\hline Fall & 11 & 34 & & 45 & & 21 & \\
\hline Spring(2001) & 11 & 29 & & 24 & & 47 & \\
\hline
\end{tabular}




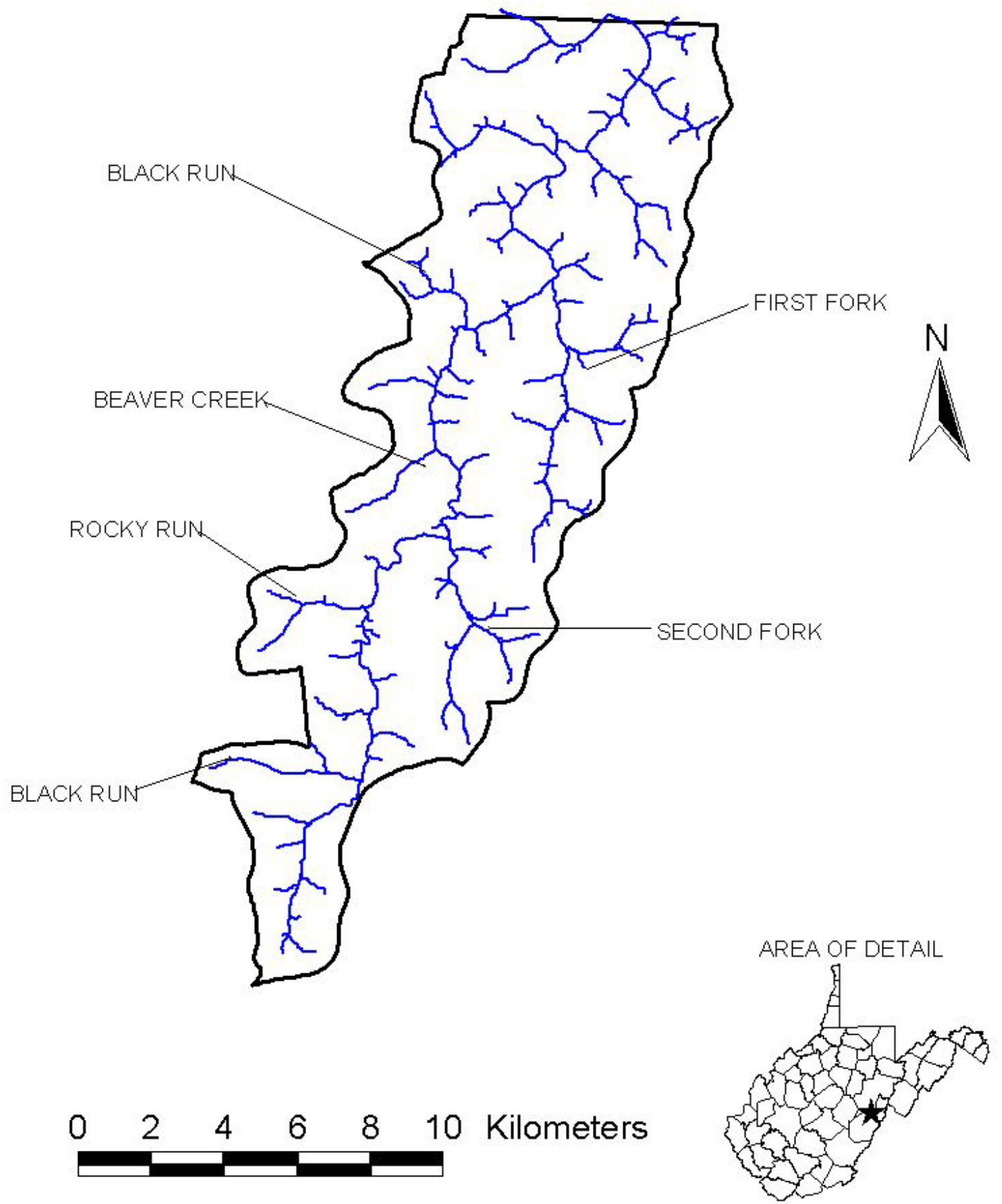

Figure 1. The upper Shavers Fork watershed of eastern West Virginia. 

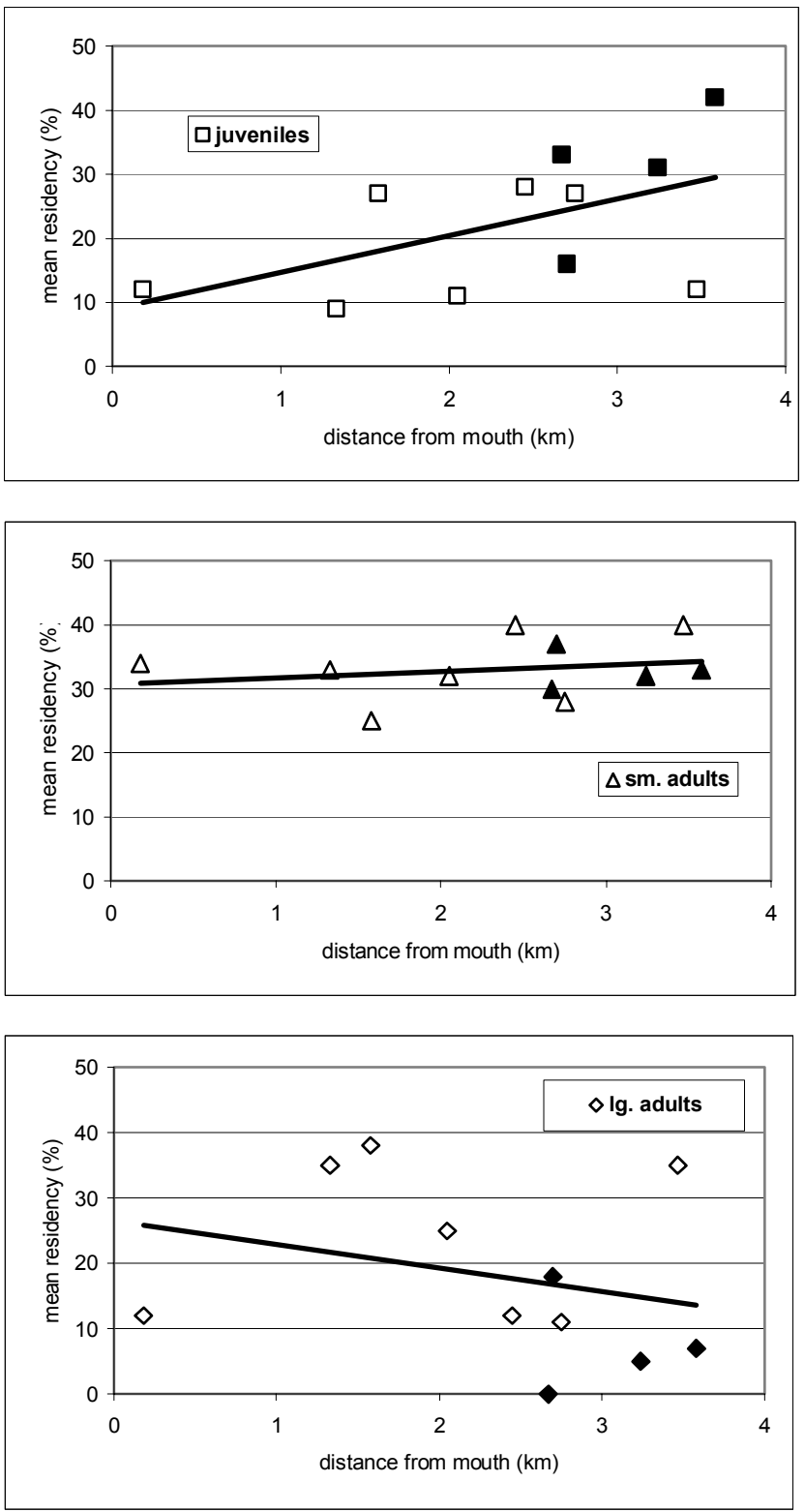

Figure 2. Spatial trends in mean residency rates for juveniles (top), small adult (middle), and large adult brook trout (bottom) within the Second Fork watershed. Black shapes indicate study sites located in tributaries to Second Fork. 
Spring 2000

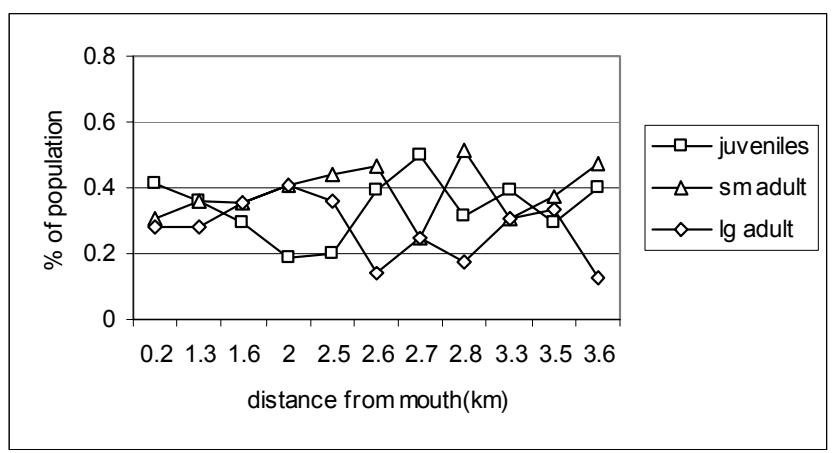

Summer 2000

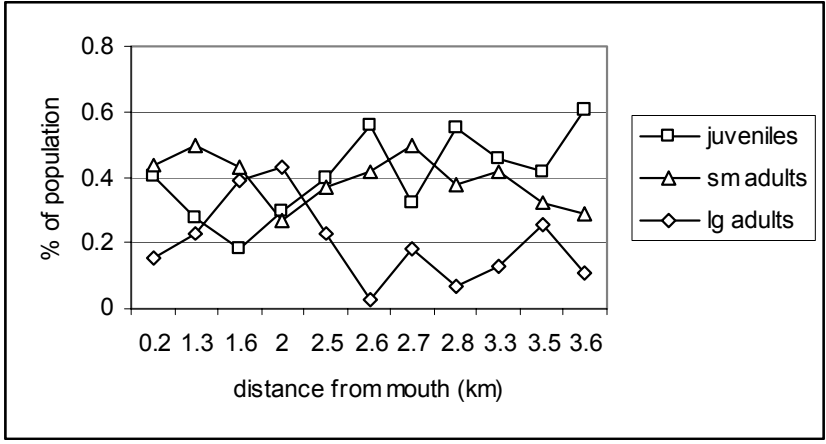

Fall 2000

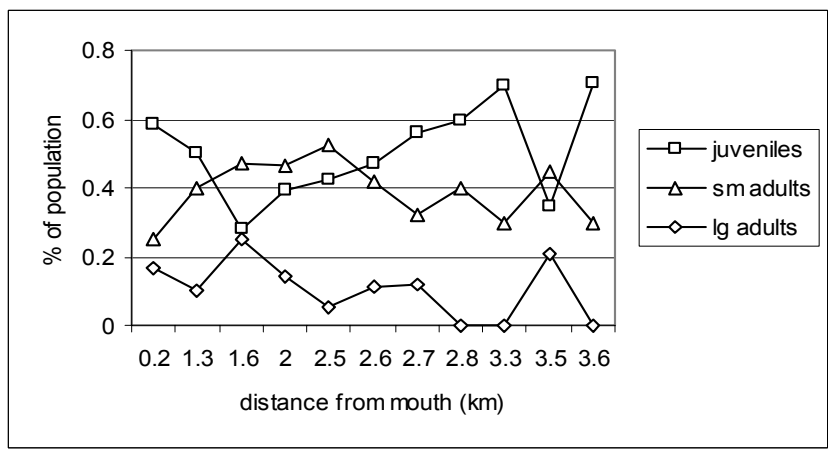

Spring 2001

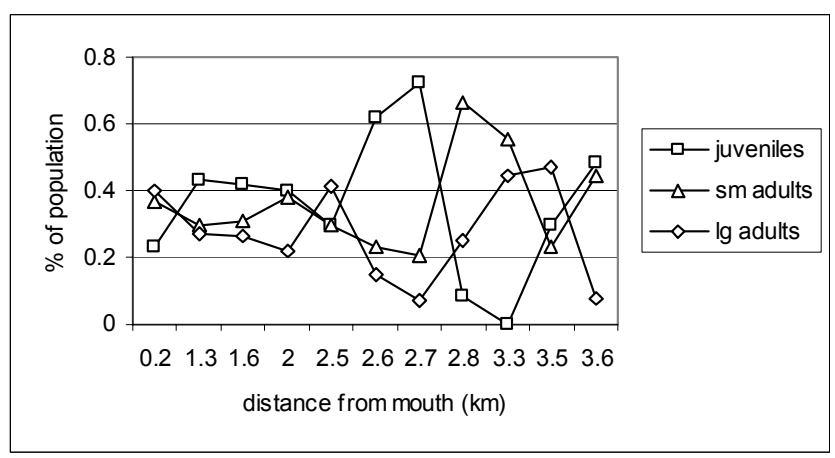

Figure 3. Spatial variation in brook trout population size structure within the Second Fork watershed for each season of the study. 


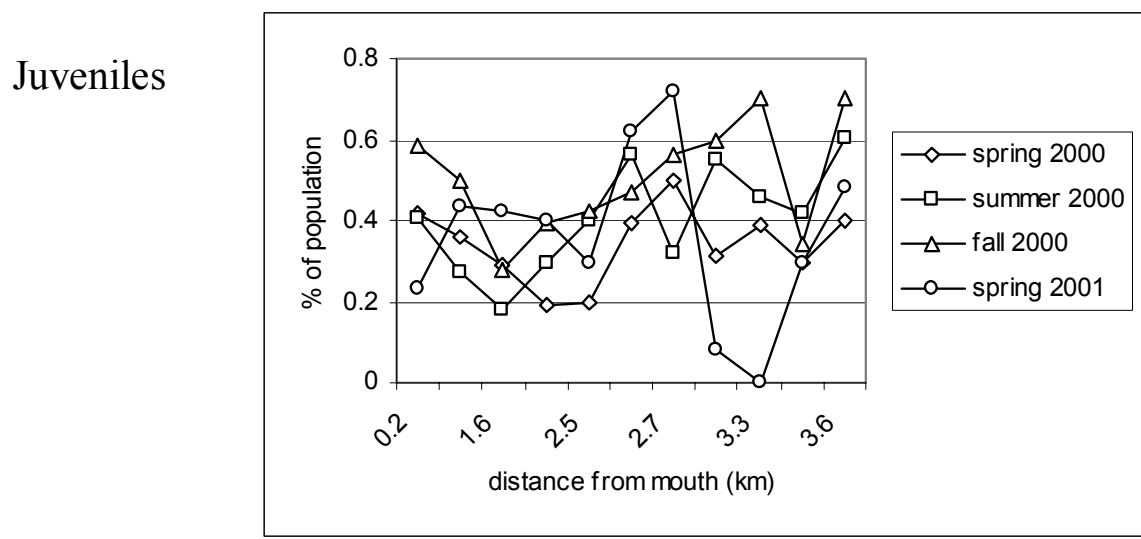

Small adults

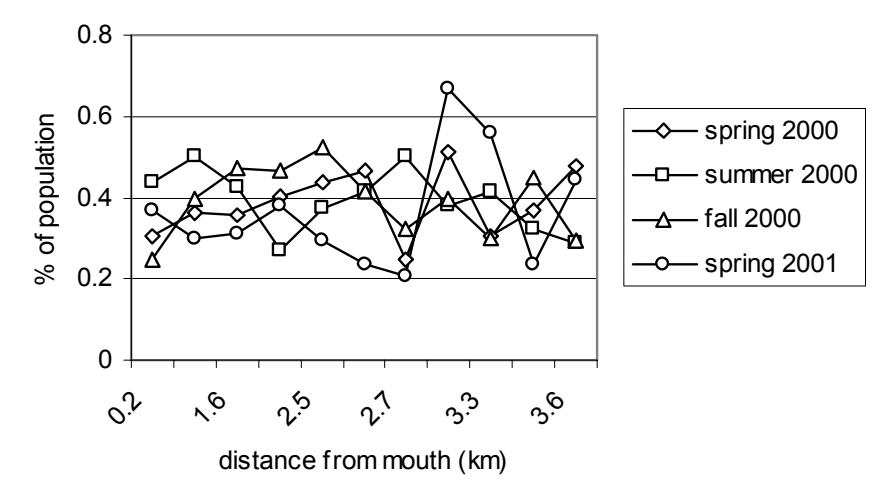

Large adults

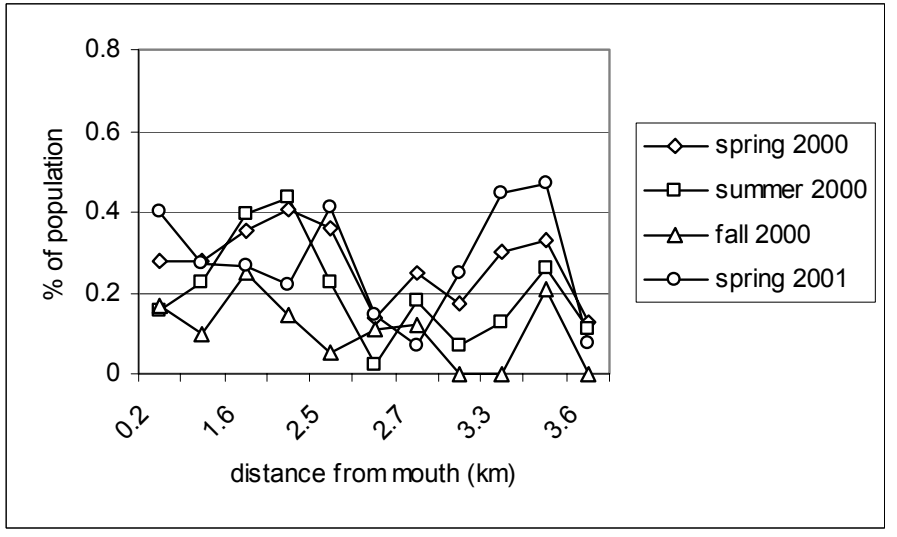

Figure 4. Seasonal variation in the relative abundance of juvenile, small adult, and large adult brook trout within the Second Fork watershed. 
Spatial stability

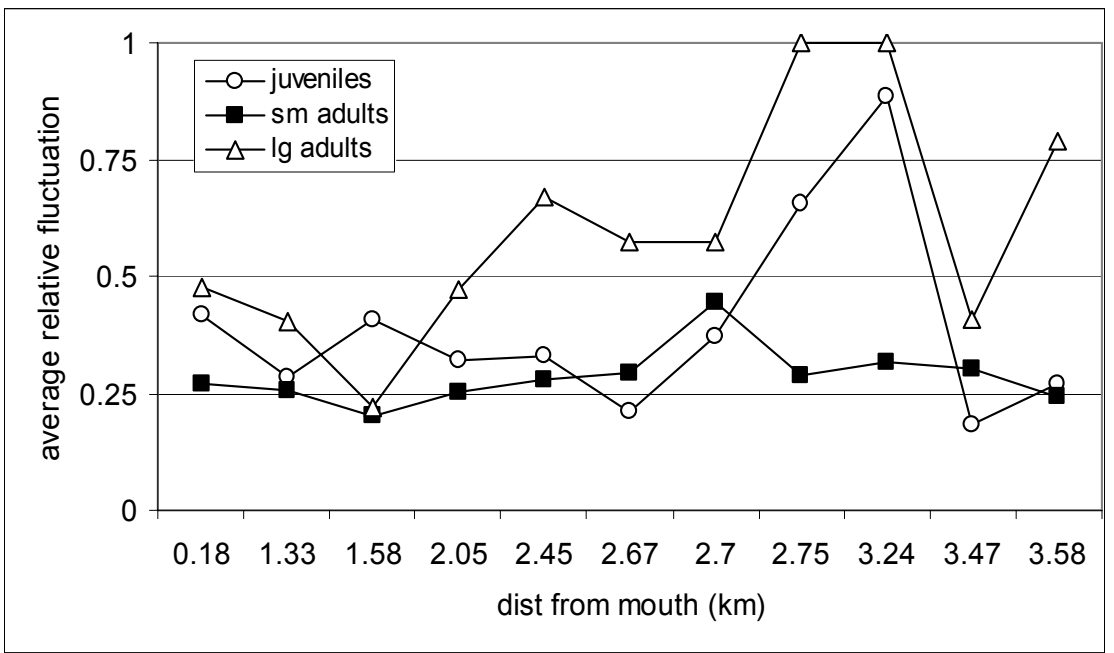

Seasonal stability

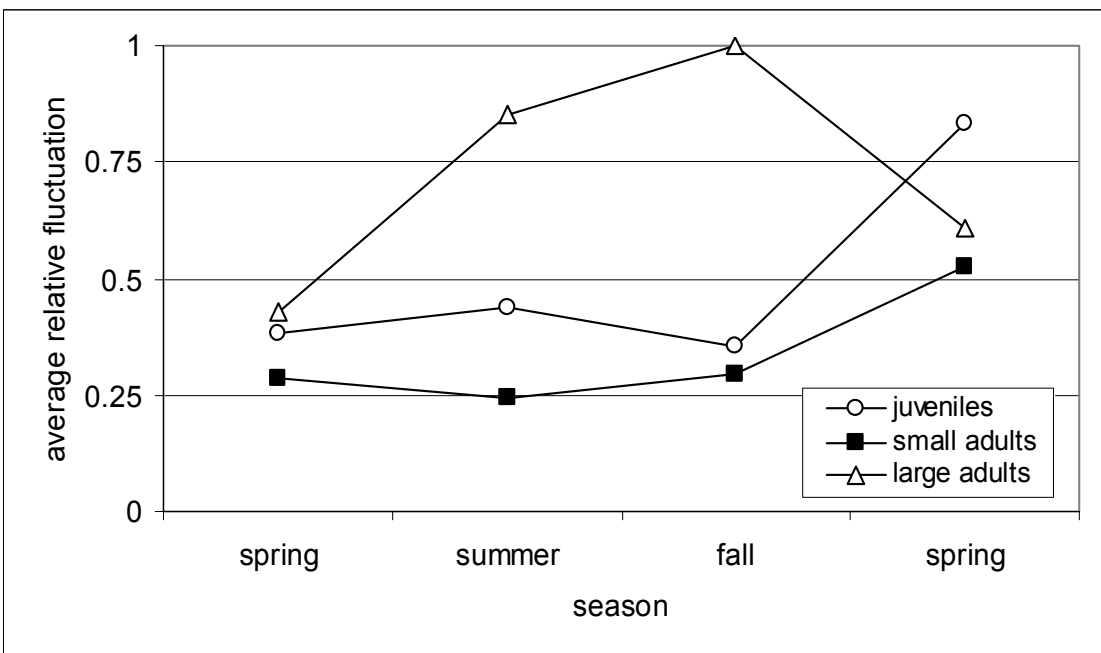

Figure 5. Spatial (top) and seasonal (bottom) average relative fluctuation of brook trout populations within the Second Fork watershed. 


\section{Appendix}

\section{Additional fish population data}

Table A1. Seasonal variation of large adult brook trout density within the Second Fork watershed.

\begin{tabular}{|c|c|c|c|c|}
\hline Site & Season & Size class & Density(\#/ha) & $\Delta$ Density $(\# /$ ha $)$ \\
\hline 1 & Spring(2000) & Ig. adult & 115.61 & \\
\hline 1 & Summer & Ig. adult & 57.80 & -57.80 \\
\hline 1 & Fall & lg. adult & 69.36 & 11.56 \\
\hline 1 & Spring(2001) & lg. adult & 138.73 & 69.36 \\
\hline 1 & Mean & lg. adult & 95.38 & 7.71 \\
\hline 2 & Spring(2000) & lg. adult & 174.50 & \\
\hline 2 & Summer & lg. adult & 137.11 & -37.39 \\
\hline 2 & Fall & lg. adult & 137.11 & 0.00 \\
\hline 2 & Spring(2001) & Ig. adult & 249.28 & 112.18 \\
\hline 2 & Mean & lg. adult & 174.50 & 24.93 \\
\hline 3 & Spring(2000) & Ig. adult & 214.27 & \\
\hline 3 & Summer & lg. adult & 138.64 & -75.62 \\
\hline 3 & Fall & lg. adult & 176.46 & 37.81 \\
\hline 3 & Spring(2001) & Ig. adult & 151.25 & -25.21 \\
\hline 3 & Mean & lg. adult & 170.15 & -21.01 \\
\hline 4 & Spring(2000) & lg. adult & 206.41 & \\
\hline 4 & Summer & lg. adult & 220.17 & 13.76 \\
\hline 4 & Fall & lg. adult & 82.57 & -137.61 \\
\hline 4 & Spring(2001) & lg. adult & 151.37 & 68.80 \\
\hline 4 & Mean & lg. adult & 165.13 & -18.35 \\
\hline 5 & Spring(2000) & Ig. adult & 138.46 & \\
\hline 5 & Summer & lg. adult & 123.08 & -15.38 \\
\hline 5 & Fall & Ig. adult & 46.15 & -76.92 \\
\hline 5 & Spring(2001) & lg. adult & 107.69 & 61.54 \\
\hline 5 & Mean & lg. adult & 103.85 & -10.26 \\
\hline 6 & Spring(2000) & Ig. adult & 125.00 & \\
\hline 6 & Summer & lg. adult & 15.63 & -109.38 \\
\hline 6 & Fall & lg. adult & 156.25 & 140.63 \\
\hline 6 & Spring(2001) & lg. adult & 156.25 & 0.00 \\
\hline 6 & Mean & lg. adult & 113.28 & 10.42 \\
\hline 7 & Spring(2000) & lg. adult & 198.35 & \\
\hline 7 & Summer & lg. adult & 66.12 & -132.23 \\
\hline 7 & Fall & Ig. adult & 0.00 & -66.12 \\
\hline 7 & Spring(2001) & Ig. adult & 99.17 & 99.17 \\
\hline 7 & Mean & lg. adult & 90.91 & -33.06 \\
\hline 8 & Spring(2000) & lg. adult & 246.00 & \\
\hline 8 & Summer & lg. adult & 123.00 & -123.00 \\
\hline 8 & Fall & Ig. adult & 147.60 & 24.60 \\
\hline 8 & Spring(2001) & lg. adult & 73.80 & -73.80 \\
\hline 8 & Mean & lg. adult & 147.60 & -57.40 \\
\hline 9 & Spring(2000) & Ig. adult & 293.38 & \\
\hline 9 & Summer & Ig. adult & 125.73 & -167.64 \\
\hline 9 & Fall & lg. adult & 41.91 & -83.82 \\
\hline 9 & Spring(2001) & lg. adult & 335.29 & 293.38 \\
\hline 9 & Mean & lg. adult & 199.08 & 13.97 \\
\hline 10 & Spring(2000) & lg. adult & 193.35 & \\
\hline 10 & Summer & Ig. adult & 309.36 & 116.01 \\
\hline 10 & Fall & lg. adult & 77.34 & -232.02 \\
\hline 10 & Spring(2001) & Ig. adult & 309.36 & 232.02 \\
\hline 10 & Mean & lg. adult & 222.35 & 38.67 \\
\hline 11 & Spring(2000) & lg. adult & 168.00 & \\
\hline 11 & Summer & lg. adult & 138.00 & -30.00 \\
\hline 11 & Fall & Ig. adult & 122.00 & -16.00 \\
\hline 11 & Spring(2001) & Ig. adult & 122.00 & 0.00 \\
\hline 11 & Mean & lg. adult & 137.50 & -15.33 \\
\hline
\end{tabular}


Table A2. Seasonal variation of juvenile brook trout density within the Second Fork watershed.

\begin{tabular}{|c|c|c|c|c|}
\hline Site & Season & Size class & Density(\#/ha) & $\Delta$ Density $(\# /$ ha $)$ \\
\hline 1 & Spring(2000) & juvenile & 173.41 & \\
\hline 1 & Summer & juvenile & 150.29 & -23.12 \\
\hline 1 & Fall & juvenile & 161.85 & 11.56 \\
\hline 1 & Spring(2001) & juvenile & 80.92 & -80.92 \\
\hline 1 & Mean & juvenile & 141.62 & -30.83 \\
\hline 2 & Spring(2000) & juvenile & 224.35 & \\
\hline 2 & Summer & juvenile & 162.03 & -62.32 \\
\hline 2 & Fall & juvenile & 186.96 & 24.93 \\
\hline 2 & Spring(2001) & juvenile & 398.85 & 211.89 \\
\hline 2 & Mean & juvenile & 243.05 & 58.17 \\
\hline 3 & Spring(2000) & juvenile & 176.46 & \\
\hline 3 & Summer & juvenile & 63.02 & -113.44 \\
\hline 3 & Fall & juvenile & 126.04 & 63.02 \\
\hline 3 & Spring(2001) & juvenile & 239.48 & 113.44 \\
\hline 3 & Mean & juvenile & 151.25 & 21.01 \\
\hline 4 & Spring(2000) & juvenile & 96.33 & \\
\hline 4 & Summer & juvenile & 151.37 & 55.04 \\
\hline 4 & Fall & juvenile & 151.37 & 0.00 \\
\hline 4 & Spring(2001) & juvenile & 247.70 & 96.33 \\
\hline 4 & Mean & juvenile & 161.69 & 50.46 \\
\hline 5 & Spring(2000) & juvenile & 61.54 & \\
\hline 5 & Summer & juvenile & 215.38 & 153.85 \\
\hline 5 & Fall & juvenile & 123.08 & -92.31 \\
\hline 5 & Spring(2001) & juvenile & 76.92 & -46.15 \\
\hline 5 & Mean & juvenile & 119.23 & 5.13 \\
\hline 6 & Spring(2000) & juvenile & 359.38 & \\
\hline 6 & Summer & juvenile & 359.38 & 0.00 \\
\hline 6 & Fall & juvenile & 265.63 & -93.75 \\
\hline 6 & Spring(2001) & juvenile & 640.63 & 375.00 \\
\hline 6 & Mean & juvenile & 406.25 & 93.75 \\
\hline 7 & Spring(2000) & juvenile & 330.58 & \\
\hline 7 & Summer & juvenile & 528.93 & 198.35 \\
\hline 7 & Fall & juvenile & 297.52 & -231.40 \\
\hline 7 & Spring(2001) & juvenile & 33.06 & -264.46 \\
\hline 7 & Mean & juvenile & 297.52 & -99.17 \\
\hline 8 & Spring(2000) & juvenile & 442.80 & \\
\hline 8 & Summer & juvenile & 221.40 & -221.40 \\
\hline 8 & Fall & juvenile & 344.40 & 123.00 \\
\hline 8 & Spring(2001) & juvenile & 762.61 & 418.20 \\
\hline 8 & Mean & juvenile & 442.80 & 106.60 \\
\hline 9 & Spring(2000) & juvenile & 377.20 & \\
\hline 9 & Summer & juvenile & 461.02 & 83.82 \\
\hline 9 & Fall & juvenile & 586.76 & 125.73 \\
\hline 9 & Spring(2001) & juvenile & 0.00 & -586.76 \\
\hline 9 & Mean & juvenile & 356.24 & -125.73 \\
\hline 10 & Spring(2000) & juvenile & 618.72 & \\
\hline 10 & Summer & juvenile & 1701.47 & 1082.75 \\
\hline 10 & Fall & juvenile & 1933.49 & 232.02 \\
\hline 10 & Spring(2001) & juvenile & 1856.15 & -77.34 \\
\hline 10 & Mean & juvenile & 1527.46 & 412.48 \\
\hline 11 & Spring(2000) & juvenile & 122.23 & \\
\hline 11 & Summer & juvenile & 198.62 & 76.39 \\
\hline 11 & Fall & juvenile & 152.79 & -45.84 \\
\hline 11 & Spring(2001) & juvenile & 76.39 & -76.39 \\
\hline 11 & Mean & juvenile & 137.51 & -15.28 \\
\hline
\end{tabular}


Table A3. Seasonal variation in small adult brook trout density within the Second Fork watershed.

\begin{tabular}{|c|c|c|c|c|}
\hline Site & Season & Size class & Density(\#/ha) & $\Delta$ Density $(\# /$ ha $)$ \\
\hline 1 & Spring(2000) & sm. adult & 127.17 & \\
\hline 1 & Summer & sm. adult & 173.41 & 46.24 \\
\hline 1 & Fall & sm. adult & 46.24 & -127.17 \\
\hline 1 & Spring(2001) & sm. adult & 127.17 & 80.92 \\
\hline 1 & Mean & sm. adult & 118.50 & 0.00 \\
\hline 2 & Spring(2000) & sm. adult & 224.35 & \\
\hline 2 & Summer & sm. adult & 274.21 & 49.86 \\
\hline 2 & Fall & sm. adult & 87.25 & -186.96 \\
\hline 2 & Spring(2001) & sm. adult & 274.21 & 186.96 \\
\hline 2 & Mean & sm. adult & 215.01 & 16.62 \\
\hline 3 & Spring(2000) & sm. adult & 214.27 & \\
\hline 3 & Summer & sm. adult & 151.25 & -63.02 \\
\hline 3 & Fall & sm. adult & 151.25 & 0.00 \\
\hline 3 & Spring(2001) & sm. adult & 176.46 & 25.21 \\
\hline 3 & Mean & sm. adult & 173.30 & -12.60 \\
\hline 4 & Spring(2000) & sm. adult & 206.41 & \\
\hline 4 & Summer & sm. adult & 137.61 & -68.80 \\
\hline 4 & Fall & sm. adult & 151.37 & 13.76 \\
\hline 4 & Spring(2001) & sm. adult & 220.17 & 68.80 \\
\hline 4 & Mean & sm. adult & 178.89 & 4.59 \\
\hline 5 & Spring(2000) & sm. adult & 184.62 & \\
\hline 5 & Summer & sm. adult & 184.62 & 0.00 \\
\hline 5 & Fall & sm. adult & 123.08 & -61.54 \\
\hline 5 & Spring(2001) & sm. adult & 76.92 & -46.15 \\
\hline 5 & Mean & sm. adult & 142.31 & -35.90 \\
\hline 6 & Spring(2000) & sm. adult & 421.88 & \\
\hline 6 & Summer & sm. adult & 265.63 & -156.25 \\
\hline 6 & Fall & sm. adult & 140.63 & -125.00 \\
\hline 6 & Spring(2001) & sm. adult & 265.63 & 125.00 \\
\hline 6 & Mean & sm. adult & 273.44 & -52.08 \\
\hline 7 & Spring(2000) & sm. adult & 628.10 & \\
\hline 7 & Summer & sm. adult & 363.64 & -264.46 \\
\hline 7 & Fall & sm. adult & 198.35 & -165.29 \\
\hline 7 & Spring(2001) & sm. adult & 264.46 & 66.12 \\
\hline 7 & Mean & sm. adult & 363.64 & -121.21 \\
\hline 8 & Spring(2000) & sm. adult & 221.40 & \\
\hline 8 & Summer & sm. adult & 319.80 & 98.40 \\
\hline 8 & Fall & sm. adult & 123.00 & -196.80 \\
\hline 8 & Spring(2001) & sm. adult & 221.40 & 98.40 \\
\hline 8 & Mean & sm. adult & 221.40 & 0.00 \\
\hline 9 & Spring(2000) & sm. adult & 293.38 & \\
\hline 9 & Summer & sm. adult & 377.20 & 83.82 \\
\hline 9 & Fall & sm. adult & 209.56 & -167.64 \\
\hline 9 & Spring(2001) & sm. adult & 419.11 & 209.56 \\
\hline 9 & Mean & sm. adult & 324.81 & 41.91 \\
\hline 10 & Spring(2000) & sm. adult & 734.73 & \\
\hline 10 & Summer & sm. adult & 812.06 & 77.34 \\
\hline 10 & Fall & sm. adult & 696.06 & -116.01 \\
\hline 10 & Spring(2001) & sm. adult & 1856.15 & 1160.09 \\
\hline 10 & Mean & sm. adult & 1024.75 & 373.81 \\
\hline 11 & Spring(2000) & sm. adult & 152.79 & \\
\hline 11 & Summer & sm. adult & 152.79 & 0.00 \\
\hline 11 & Fall & sm. adult & 122.23 & -30.56 \\
\hline 11 & Spring(2001) & sm. adult & 61.12 & -61.12 \\
\hline 11 & Mean & sm. adult & 122.23 & -30.56 \\
\hline
\end{tabular}


Table A4. Fish community sampling results for the upper Shavers Fork during 2000. *Site 12 was located approximately $200 \mathrm{~m}$ upstream from the mouth of Beaver Creek and ** Site 13 was located upstream of the mouth of Rocky Run (Figure 1, Chapter 1).

\begin{tabular}{|c|c|c|c|c|}
\hline Season & Stream & Site\# & Species & \# Captured \\
\hline \multirow[t]{13}{*}{ spring } & Shavers Fork & $12 *$ & Campostoma anomalum & 98 \\
\hline & & & Catostomus commersoni & 15 \\
\hline & & & Clinostomus funduloides & 91 \\
\hline & & & Cottus bairdi & 176 \\
\hline & & & Etheostoma flabellare & 139 \\
\hline & & & Hypentelium nigricans & 40 \\
\hline & & & Nocomis micropogon & 78 \\
\hline & & & Phoxinus oreas & 60 \\
\hline & & & Rhinichthys cataractae & 71 \\
\hline & & & Semotilus atromaculatus & 9 \\
\hline & & & Rhinichthys atratulus & 70 \\
\hline & & & Salvelinus fontinalis & 1 \\
\hline & & & Salmo trutta & 7 \\
\hline \multirow[t]{14}{*}{ spring } & Shavers Fork & $13^{* *}$ & Campostoma anomalum & 32 \\
\hline & & & Catostomus commersoni & 67 \\
\hline & & & Clinostomus funduloides & 58 \\
\hline & & & Cottus bairdi & 224 \\
\hline & & & Etheostoma flabellare & 146 \\
\hline & & & Hypentelium nigricans & 37 \\
\hline & & & Nocomis micropogon & 13 \\
\hline & & & Phoxinus oreas & 7 \\
\hline & & & Rhinichthys cataractae & 45 \\
\hline & & & Semotilus atromaculatus & 44 \\
\hline & & & Rhinichthys atratulus & 228 \\
\hline & & & Salvelinus fontinalis & 16 \\
\hline & & & Salmo trutta & 2 \\
\hline & & & Onchorhynchus mykiss & 2 \\
\hline
\end{tabular}




\begin{tabular}{|c|c|c|c|c|}
\hline Season & Stream & Site\# & Species & \# Captured \\
\hline \multirow[t]{14}{*}{ summer } & Shavers Fork & 13 & Campostoma anomalum & 24 \\
\hline & & & Catostomus commersoni & 61 \\
\hline & & & Clinostomus funduloides & 43 \\
\hline & & & Cottus bairdi & 220 \\
\hline & & & Etheostoma flabellare & 95 \\
\hline & & & Hypentelium nigricans & 42 \\
\hline & & & Lepomis cyanellus & 1 \\
\hline & & & Nocomis micropogon & 13 \\
\hline & & & Oncorhynchus mykiss & 2 \\
\hline & & & Phoxinus oreas & 2 \\
\hline & & & Rhinichthys atratulus & 204 \\
\hline & & & Rhinichthys cataractae & 30 \\
\hline & & & Salvelinus fontinalis & 10 \\
\hline & & & Semotilus atromaculatus & 53 \\
\hline
\end{tabular}


Table A5. Brook trout instantaneous growth rates within the Second Fork watershed.

\begin{tabular}{|c|c|c|c|c|c|c|c|}
\hline Site & Size class & Season & $\mathrm{n}$ & Mean growth $\left(\% \mathrm{~d}^{-1}\right)$ & S.E. & Min & Max \\
\hline \multirow[t]{3}{*}{1} & juvenile & summer & 0 & - & - & - & - \\
\hline & & fall & 3 & -0.12 & 0.08 & -0.27 & -0.02 \\
\hline & & winter/spring & 2 & 0.42 & 0.01 & 0.41 & 0.43 \\
\hline \multirow[t]{3}{*}{2} & juvenile & summer & 1 & 1.89 & - & 1.89 & 1.89 \\
\hline & & fall & 1 & 0.12 & - & 0.12 & 0.12 \\
\hline & & winter/spring & 2 & 0.43 & 0.24 & 0.20 & 0.67 \\
\hline \multirow[t]{3}{*}{3} & juvenile & summer & 0 & - & - & - & - \\
\hline & & fall & 2 & 0.33 & 0.13 & 0.20 & 0.46 \\
\hline & & winter/spring & 4 & 0.34 & 0.04 & 0.28 & 0.45 \\
\hline \multirow[t]{3}{*}{4} & juvenile & summer & 1 & 2.70 & - & 2.70 & 2.70 \\
\hline & & fall & 0 & - & - & - & - \\
\hline & & winter/spring & 2 & 0.33 & 0.02 & 0.31 & 0.36 \\
\hline \multirow[t]{3}{*}{5} & juvenile & summer & 2 & 0.56 & 0.10 & 0.46 & 0.67 \\
\hline & & fall & 1 & 0.54 & - & 0.54 & 0.54 \\
\hline & & winter/spring & 3 & 0.38 & 0.07 & 0.26 & 0.52 \\
\hline \multirow[t]{3}{*}{6} & juvenile & summer & 7 & 1.49 & 0.35 & 0.43 & 2.67 \\
\hline & & fall & 5 & 0.54 & 0.20 & 0.01 & 1.78 \\
\hline & & winter/spring & 8 & 0.29 & 0.05 & 0.14 & 0.54 \\
\hline \multirow[t]{3}{*}{7} & juvenile & summer & 2 & 2.54 & 0.33 & 2.20 & 2.87 \\
\hline & & fall & 1 & 0.38 & - & 0.38 & 0.38 \\
\hline & & winter/spring & 5 & 0.30 & 0.03 & 0.23 & 0.43 \\
\hline \multirow[t]{3}{*}{8} & juvenile & summer & 1 & 0.71 & - & 0.71 & 0.71 \\
\hline & & fall & 2 & 1.06 & 0.13 & 0.93 & 1.20 \\
\hline & & winter/spring & 3 & 0.40 & 0.06 & 0.32 & 0.52 \\
\hline \multirow[t]{3}{*}{9} & juvenile & summer & 5 & 1.38 & 0.34 & 0.43 & 2.46 \\
\hline & & fall & 1 & 0.41 & - & 0.41 & 0.41 \\
\hline & & winter/spring & 4 & 0.44 & 0.04 & 0.35 & 0.52 \\
\hline \multirow[t]{3}{*}{10} & juvenile & summer & 12 & 1.75 & 0.33 & 0.15 & 3.25 \\
\hline & & fall & 8 & 0.34 & 0.16 & -0.16 & 0.98 \\
\hline & & winter/spring & 17 & 0.31 & 0.04 & 0.07 & 0.65 \\
\hline \multirow[t]{3}{*}{11} & juvenile & summer & 2 & 2.24 & 0.31 & 1.93 & 2.55 \\
\hline & & fall & 0 & 0 & - & - & - \\
\hline & & winter/spring & 1 & 0.32 & - & 0.32 & 0.32 \\
\hline
\end{tabular}




\begin{tabular}{|c|c|c|c|c|c|c|c|}
\hline Site & Size class & Season & $\mathrm{n}$ & Mean growth $\left(\% \mathrm{~d}^{-1}\right)$ & S.E. & Min & Max \\
\hline \multirow[t]{3}{*}{1} & small adult & summer & 5 & 0.55 & 0.15 & 0.19 & 0.95 \\
\hline & & fall & 1 & 0.33 & - & 0.33 & 0.33 \\
\hline & & winter/spring & 3 & 0.41 & 0.09 & 0.25 & 0.55 \\
\hline \multirow[t]{3}{*}{2} & small adult & summer & 6 & 0.26 & 0.13 & -0.06 & 0.84 \\
\hline & & fall & 5 & 0.21 & 0.10 & -0.10 & 0.40 \\
\hline & & winter/spring & 5 & 0.36 & 0.10 & 0.15 & 0.72 \\
\hline \multirow[t]{3}{*}{3} & small adult & summer & 7 & 0.28 & 0.10 & -0.12 & 0.65 \\
\hline & & fall & 2 & 0.32 & 0.05 & 0.27 & 0.37 \\
\hline & & winter/spring & 3 & 0.22 & 0.02 & 0.17 & 0.25 \\
\hline \multirow[t]{3}{*}{4} & small adult & summer & 2 & 0.79 & 0.16 & 0.63 & 0.94 \\
\hline & & fall & 3 & 0.30 & 0.09 & 0.13 & 0.41 \\
\hline & & winter/spring & 5 & 0.18 & 0.05 & -0.01 & 0.30 \\
\hline \multirow[t]{3}{*}{5} & small adult & summer & 6 & 0.56 & 0.13 & 0.35 & 1.15 \\
\hline & & fall & 6 & 0.45 & 0.11 & 0.09 & 0.80 \\
\hline & & winter/spring & 2 & 0.51 & 0.04 & 0.47 & 0.55 \\
\hline \multirow[t]{3}{*}{6} & small adult & summer & 12 & 0.32 & 0.08 & -0.23 & 0.67 \\
\hline & & fall & 3 & 0.28 & 0.09 & 0.11 & 0.43 \\
\hline & & winter/spring & 4 & 0.13 & 0.02 & 0.09 & 0.16 \\
\hline \multirow[t]{3}{*}{7} & small adult & summer & 6 & 0.51 & 0.13 & 0.12 & 0.95 \\
\hline & & fall & 3 & -0.01 & 0.21 & -0.15 & 0.15 \\
\hline & & winter/spring & 1 & 0.13 & - & 0.13 & 0.13 \\
\hline \multirow[t]{3}{*}{8} & small adult & summer & 4 & 0.20 & 0.11 & -0.12 & 0.39 \\
\hline & & fall & 6 & 0.46 & 0.07 & 0.20 & 0.71 \\
\hline & & winter/spring & 2 & 0.15 & 0.02 & 0.13 & 0.18 \\
\hline \multirow[t]{3}{*}{9} & small adult & summer & 3 & 0.36 & 0.07 & 0.24 & 0.49 \\
\hline & & fall & 2 & -0.20 & 0.16 & -0.36 & -0.04 \\
\hline & & winter/spring & 2 & 0.17 & 0.06 & 0.11 & 0.23 \\
\hline \multirow[t]{3}{*}{10} & small adult & summer & 7 & 0.40 & 0.14 & 0.03 & 1.22 \\
\hline & & fall & 10 & -0.01 & 0.05 & -0.31 & 0.18 \\
\hline & & winter/spring & 3 & 0.12 & 0.02 & 0.07 & 0.15 \\
\hline \multirow[t]{3}{*}{11} & small adult & summer & 4 & 0.63 & 0.12 & 0.26 & 0.81 \\
\hline & & fall & 5 & 0.18 & 0.10 & -0.09 & 0.49 \\
\hline & & winter/spring & 4 & 0.21 & 0.03 & 0.14 & 0.27 \\
\hline
\end{tabular}




\begin{tabular}{|c|c|c|c|c|c|c|c|}
\hline Site & Size class & Season & $\mathrm{n}$ & Mean growth $\left(\% \mathrm{~d}^{-1}\right)$ & S.E. & Min & Max \\
\hline \multirow[t]{3}{*}{1} & large adult & summer & 1 & 0.12 & - & 0.12 & 0.12 \\
\hline & & fall & 0 & - & - & - & - \\
\hline & & winter/spring & 1 & 0.29 & - & 0.29 & 0.29 \\
\hline \multirow[t]{3}{*}{2} & large adult & summer & 6 & 0.08 & 0.05 & -0.09 & 0.22 \\
\hline & & fall & 3 & -0.21 & 0.03 & -0.27 & -0.16 \\
\hline & & winter/spring & 1 & 0.25 & - & 0.25 & 0.25 \\
\hline \multirow[t]{3}{*}{3} & large adult & summer & 5 & 0.22 & 0.12 & -0.25 & 0.43 \\
\hline & & fall & 7 & 0.08 & 0.12 & -0.50 & 0.56 \\
\hline & & winter/spring & 2 & 0.29 & 0.12 & 0.17 & 0.41 \\
\hline \multirow[t]{3}{*}{4} & large adult & summer & 2 & 0.40 & 0.06 & 0.34 & 0.46 \\
\hline & & fall & 2 & 0.03 & 0.29 & -0.26 & 0.31 \\
\hline & & winter/spring & 2 & 0.13 & 0.03 & 0.10 & 0.15 \\
\hline \multirow[t]{3}{*}{5} & large adult & summer & 2 & 0.01 & 0.18 & -0.17 & 0.18 \\
\hline & & fall & 1 & -0.34 & - & -0.34 & -0.34 \\
\hline & & winter/spring & 0 & - & - & - & - \\
\hline \multirow[t]{3}{*}{6} & large adult & summer & 0 & - & - & - & - \\
\hline & & fall & 0 & - & - & - & - \\
\hline & & winter/spring & 0 & - & - & - & - \\
\hline \multirow[t]{3}{*}{7} & large adult & summer & 2 & 0.45 & 0.29 & 0.16 & 0.74 \\
\hline & & fall & - & - & - & - & - \\
\hline & & winter/spring & - & - & - & - & - \\
\hline \multirow[t]{3}{*}{8} & large adult & summer & 3 & 0.27 & 0.21 & 0.05 & 0.69 \\
\hline & & fall & 1 & -0.10 & - & -0.10 & -0.10 \\
\hline & & winter/spring & 0 & - & - & - & - \\
\hline \multirow[t]{3}{*}{9} & large adult & summer & 1 & 0.30 & - & 0.30 & 0.30 \\
\hline & & fall & - & - & - & - & - \\
\hline & & winter/spring & - & - & - & - & - \\
\hline \multirow[t]{3}{*}{10} & large adult & summer & 1 & 0.15 & - & 0.15 & 0.15 \\
\hline & & fall & 0 & - & - & - & - \\
\hline & & winter/spring & 0 & - & - & - & - \\
\hline \multirow[t]{3}{*}{11} & large adult & summer & 3 & 0.17 & 0.04 & 0.09 & 0.24 \\
\hline & & fall & 3 & -0.18 & 0.03 & -0.23 & -0.14 \\
\hline & & winter/spring & 2 & 0.12 & 0.11 & 0.01 & 0.23 \\
\hline
\end{tabular}


Table A6. Summary of juvenile brook trout mark-recapture results.

\begin{tabular}{|c|c|c|c|c|c|c|}
\hline Site & Season & Marked & Recaptured & Residents & Immigrants & Emigrants \\
\hline 1 & Spring 2000 & 15 & 0 & 0 & 0 & 0 \\
\hline 1 & Summer & 13 & 0 & 0 & 13 & 15 \\
\hline 1 & Fall & 14 & 4 & 3 & 11 & 9 \\
\hline 1 & Spring 2001 & 11 & 2 & 2 & 9 & 12 \\
\hline 2 & Spring 2000 & 18 & 0 & 0 & 0 & 0 \\
\hline 2 & Summer & 12 & 1 & 1 & 11 & 12 \\
\hline 2 & Fall & 15 & 1 & 1 & 14 & 10 \\
\hline 2 & Spring 2001 & 22 & 3 & 2 & 20 & 13 \\
\hline 3 & Spring 2000 & 14 & 0 & 0 & 0 & 0 \\
\hline 3 & Summer & 5 & 0 & 0 & 5 & 14 \\
\hline 3 & Fall & 10 & 2 & 2 & 8 & 3 \\
\hline 3 & Spring 2001 & 14 & 4 & 4 & 10 & 6 \\
\hline 4 & Spring 2000 & 7 & 0 & 0 & 0 & 0 \\
\hline 4 & Summer & 11 & 1 & 1 & 10 & 6 \\
\hline 4 & Fall & 11 & 0 & 0 & 11 & 11 \\
\hline 4 & Spring 2001 & 16 & 3 & 2 & 14 & 9 \\
\hline 5 & Spring 2000 & 5 & 0 & 0 & 0 & 0 \\
\hline 5 & Summer & 14 & 2 & 2 & 12 & 3 \\
\hline 5 & Fall & 8 & 2 & 1 & 7 & 11 \\
\hline 5 & Spring 2001 & 5 & 3 & 3 & 2 & 5 \\
\hline 6 & Spring 2000 & 23 & 0 & 0 & 0 & 0 \\
\hline 6 & Summer & 23 & 7 & 7 & 16 & 16 \\
\hline 6 & Fall & 17 & 5 & 5 & 12 & 18 \\
\hline 6 & Spring 2001 & 17 & 9 & 8 & 9 & 7 \\
\hline 7 & Spring 2000 & 11 & 0 & 0 & 0 & 0 \\
\hline 7 & Summer & 16 & 2 & 2 & 14 & 8 \\
\hline 7 & Fall & 9 & 2 & 1 & 8 & 14 \\
\hline 7 & Spring 2001 & 8 & 5 & 5 & 3 & 4 \\
\hline 8 & Spring 2000 & 18 & 0 & 0 & 0 & 0 \\
\hline 8 & Summer & 9 & 1 & 1 & 8 & 16 \\
\hline 8 & Fall & 14 & 2 & 2 & 12 & 7 \\
\hline 8 & Spring 2001 & 9 & 4 & 3 & 6 & 11 \\
\hline 9 & Spring 2000 & 9 & 0 & 0 & 0 & 0 \\
\hline 9 & Summer & 11 & 5 & 5 & 6 & 4 \\
\hline 9 & Fall & 14 & 1 & 1 & 13 & 10 \\
\hline 9 & Spring 2001 & 10 & 4 & 4 & 6 & 10 \\
\hline 10 & Spring 2000 & 16 & 0 & 0 & 0 & 0 \\
\hline 10 & Summer & 44 & 12 & 12 & 32 & 3 \\
\hline 10 & Fall & 50 & 8 & 8 & 42 & 31 \\
\hline 10 & Spring 2001 & 47 & 20 & 17 & 30 & 31 \\
\hline 11 & Spring 2000 & 8 & 0 & 0 & 0 & 0 \\
\hline 11 & Summer & 13 & 2 & 2 & 11 & 6 \\
\hline 11 & Fall & 10 & 1 & 0 & 10 & 12 \\
\hline 11 & Spring 2001 & 4 & 1 & 1 & 3 & 9 \\
\hline
\end{tabular}


Table A7. Summary of small adult brook trout mark-recapture results.

\begin{tabular}{|c|c|c|c|c|c|c|}
\hline Site & Season & Marked & Recaptured & Residents & Immigrants & Emigrants \\
\hline 1 & Spring 2000 & 11 & 0 & 0 & 0 & 0 \\
\hline 1 & Summer & 14 & 5 & 5 & 9 & 5 \\
\hline 1 & Fall & 6 & 2 & 1 & 5 & 12 \\
\hline 1 & Spring 2001 & 3 & 3 & 3 & 0 & 3 \\
\hline 2 & Spring 2000 & 18 & 0 & 0 & 0 & 0 \\
\hline 2 & Summer & 22 & 6 & 6 & 16 & 11 \\
\hline 2 & Fall & 12 & 7 & 5 & 7 & 17 \\
\hline 2 & Spring 2001 & 15 & 8 & 5 & 10 & 7 \\
\hline 3 & Spring 2000 & 17 & 0 & 0 & 0 & 0 \\
\hline 3 & Summer & 12 & 7 & 7 & 5 & 10 \\
\hline 3 & Fall & 17 & 7 & 2 & 15 & 10 \\
\hline 3 & Spring 2001 & 8 & 7 & 3 & 5 & 14 \\
\hline 4 & Spring 2000 & 15 & 0 & 0 & 0 & 0 \\
\hline 4 & Summer & 10 & 2 & 2 & 8 & 13 \\
\hline 4 & Fall & 13 & 6 & 3 & 10 & 7 \\
\hline 4 & Spring 2001 & 7 & 6 & 5 & 2 & 8 \\
\hline 5 & Spring 2000 & 11 & 0 & 0 & 0 & 0 \\
\hline 5 & Summer & 13 & 5 & 5 & 8 & 6 \\
\hline 5 & Fall & 10 & 7 & 6 & 4 & 7 \\
\hline 5 & Spring 2001 & 7 & 5 & 2 & 5 & 7 \\
\hline 6 & Spring 2000 & 27 & 0 & 0 & 0 & 0 \\
\hline 6 & Summer & 17 & 12 & 12 & 5 & 15 \\
\hline 6 & Fall & 15 & 9 & 3 & 12 & 14 \\
\hline 6 & Spring 2001 & 8 & 7 & 4 & 4 & 11 \\
\hline 7 & Spring 2000 & 18 & 0 & 0 & 0 & 0 \\
\hline 7 & Summer & 11 & 6 & 6 & 5 & 12 \\
\hline 7 & Fall & 6 & 4 & 3 & 3 & 8 \\
\hline 7 & Spring 2001 & 3 & 2 & 1 & 2 & 5 \\
\hline 8 & Spring 2000 & 9 & 0 & 0 & 0 & 0 \\
\hline 8 & Summer & 14 & 4 & 4 & 10 & 4 \\
\hline 8 & Fall & 8 & 7 & 6 & 2 & 8 \\
\hline 8 & Spring 2001 & 3 & 2 & 2 & 1 & 6 \\
\hline 9 & Spring 2000 & 7 & 0 & 0 & 0 & 0 \\
\hline 9 & Summer & 10 & 3 & 3 & 7 & 4 \\
\hline 9 & Fall & 6 & 3 & 2 & 4 & 8 \\
\hline 9 & Spring 2001 & 8 & 6 & 2 & 6 & 4 \\
\hline 10 & Spring 2000 & 19 & 0 & 0 & 0 & 0 \\
\hline 10 & Summer & 21 & 7 & 7 & 14 & 12 \\
\hline 10 & Fall & 21 & 12 & 10 & 11 & 10 \\
\hline 10 & Spring 2001 & 5 & 3 & 3 & 2 & 17 \\
\hline 11 & Spring 2000 & 10 & 0 & 0 & 0 & 0 \\
\hline 11 & Summer & 10 & 4 & 4 & 6 & 6 \\
\hline 11 & Fall & 13 & 9 & 5 & 8 & 5 \\
\hline 11 & Spring 2001 & 6 & 4 & 4 & 2 & 9 \\
\hline
\end{tabular}


Table A8. Summary of large adult brook trout mark-recapture results.

\begin{tabular}{|c|c|c|c|c|c|c|}
\hline Site & Season & Marked & Recaptured & Residents & Immigrants & Emigrants \\
\hline 1 & Spring 2000 & 10 & 0 & 0 & 0 & 0 \\
\hline 1 & Summer & 5 & 1 & 1 & 4 & 9 \\
\hline 1 & Fall & 4 & 0 & 0 & 4 & 5 \\
\hline 1 & Spring 2001 & 9 & 6 & 1 & 8 & 3 \\
\hline 2 & Spring 2000 & 14 & 0 & 0 & 0 & 0 \\
\hline 2 & Summer & 10 & 6 & 6 & 4 & 8 \\
\hline 2 & Fall & 3 & 3 & 3 & 0 & 7 \\
\hline 2 & Spring 2001 & 5 & 2 & 1 & 4 & 2 \\
\hline 3 & Spring 2000 & 17 & 0 & 0 & 0 & 0 \\
\hline 3 & Summer & 11 & 5 & 5 & 6 & 12 \\
\hline 3 & Fall & 9 & 7 & 7 & 2 & 4 \\
\hline 3 & Spring 2001 & 4 & 2 & 2 & 2 & 7 \\
\hline 4 & Spring 2000 & 15 & 0 & 0 & 0 & 0 \\
\hline 4 & Summer & 16 & 2 & 2 & 14 & 13 \\
\hline 4 & Fall & 4 & 4 & 2 & 2 & 14 \\
\hline 4 & Spring 2001 & 4 & 2 & 2 & 2 & 2 \\
\hline 5 & Spring 2000 & 9 & 0 & 0 & 0 & 0 \\
\hline 5 & Summer & 8 & 2 & 2 & 6 & 7 \\
\hline 5 & Fall & 1 & 1 & 1 & 0 & 7 \\
\hline 5 & Spring 2001 & 0 & 0 & 0 & 0 & 1 \\
\hline 6 & Spring 2000 & 8 & 0 & 0 & 0 & 0 \\
\hline 6 & Summer & 1 & 0 & 0 & 1 & 8 \\
\hline 6 & Fall & 4 & 1 & 0 & 4 & 1 \\
\hline 6 & Spring 2001 & 2 & 2 & 0 & 2 & 4 \\
\hline 7 & Spring 2000 & 6 & 0 & 0 & 0 & 0 \\
\hline 7 & Summer & 2 & 2 & 2 & 0 & 4 \\
\hline 7 & Fall & 0 & 0 & 0 & 0 & 2 \\
\hline 7 & Spring 2001 & 0 & 0 & 0 & 0 & 0 \\
\hline 8 & Spring 2000 & 9 & 0 & 0 & 0 & 0 \\
\hline 8 & Summer & 5 & 3 & 3 & 2 & 6 \\
\hline 8 & Fall & 3 & 1 & 1 & 2 & 4 \\
\hline 8 & Spring 2001 & 0 & 0 & 0 & 0 & 3 \\
\hline 9 & Spring 2000 & 7 & 0 & 0 & 0 & 0 \\
\hline 9 & Summer & 3 & 1 & 1 & 2 & 6 \\
\hline 9 & Fall & 0 & 0 & 0 & 0 & 3 \\
\hline 9 & Spring 2001 & 0 & 0 & 0 & 0 & 0 \\
\hline 10 & Spring 2000 & 5 & 0 & 0 & 0 & 0 \\
\hline 10 & Summer & 8 & 1 & 1 & 7 & 4 \\
\hline 10 & Fall & 0 & 0 & 0 & 0 & 7 \\
\hline 10 & Spring 2001 & 3 & 2 & 0 & 3 & 0 \\
\hline 11 & Spring 2000 & 9 & 0 & 0 & 0 & 0 \\
\hline 11 & Summer & 8 & 3 & 3 & 5 & 6 \\
\hline 11 & Fall & 6 & 3 & 3 & 3 & 5 \\
\hline 11 & Spring 2001 & 2 & 2 & 2 & 0 & 4 \\
\hline
\end{tabular}




\section{Additional stream habitat data}

Table A9. Location descriptions for sampling sites within the Second Fork watershed.

\begin{tabular}{ccccc}
\hline Site & Latitude & Longitude & Elevation $(\mathrm{m})$ & Distance to mouth(km) \\
\hline 1 & $38^{\circ} 30.087^{\prime}$ & $79^{\circ} 55.912^{\prime}$ & 1142 & 0.18 \\
2 & $38^{\circ} 29.553^{\prime}$ & $79^{\circ} 55.940^{\prime}$ & 1153 & 1.33 \\
3 & $38^{\circ} 29.451^{\prime}$ & $79^{\circ} 55.840^{\prime}$ & 1159 & 1.58 \\
4 & $38^{\circ} 29.224^{\prime}$ & $79^{\circ} 55.734^{\prime}$ & 1171 & 2.05 \\
5 & $38^{\circ} 29.031^{\prime}$ & $79^{\circ} 55.614^{\prime}$ & 1188 & 2.45 \\
6 & $38^{\circ} 28.956^{\prime}$ & $79^{\circ} 55.450^{\prime}$ & 1207 & 2.67 \\
7 & $38^{\circ} 28.885^{\prime}$ & $79^{\circ} 55.528^{\prime}$ & 1199 & 2.75 \\
8 & $38^{\circ} 28.899^{\prime}$ & $79^{\circ} 55.501^{\prime}$ & 1200 & 2.70 \\
9 & $38^{\circ} 28.729^{\prime}$ & $79^{\circ} 55.199^{\prime}$ & 1234 & 3.24 \\
10 & $38^{\circ} 28.651^{\prime}$ & $79^{\circ} 54.990^{\prime}$ & 1251 & 3.58 \\
11 & $38^{\circ} 28.561^{\prime}$ & $79^{\circ} 55.813^{\prime}$ & 1235 & 3.47 \\
\hline
\end{tabular}


Table A10. Stream channel unit delineation for the Second Fork watershed. The survey began at the mouth of Second Fork and continued working upstream throughout the watershed. The beginning of study sites are noted by S\#. The right channel (facing upstream) of a braided section of stream is noted by $*$. igr $=$ intermediate grade riffle, $\operatorname{lgr}=$ low gradient riffle.

\begin{tabular}{|c|c|c|c|c|c|}
\hline stream & channel unit & endpoint (m) & stream & channel unit & endpoint (m) \\
\hline second ${ }^{\text {mouth }}$ & igr & 51 & second & igr & 1688 \\
\hline second & glide & 70 & second & bluff pool & 1718 \\
\hline second & riffle/run & 131 & second & glide & 1747 \\
\hline second & bluff pool & 149 & second $^{\mathrm{S} 3}$ & $\lg r$ & 1755 \\
\hline second & $\lg r$ & 245 & second & riffle/run & 1780 \\
\hline second $^{\mathrm{S} 1}$ & glide & 267 & second & cascade & 1842 \\
\hline second & $\operatorname{lgr}$ & 288 & second & igr & 1892 \\
\hline second & glide & 310 & second & plunge pool & 1918 \\
\hline second & bluff pool & 330 & second & igr & 1939 \\
\hline second & igr & 345 & second & plunge pool & 1944 \\
\hline second & bluff pool & 351 & second & plunge pool* & $1984^{*}$ \\
\hline second & igr & 388 & second & $\lg r$ & 1984 \\
\hline second & glide & 412 & second & plunge pool & 1996 \\
\hline second & $\lg r$ & 580 & second & $\lg r$ & 2037 \\
\hline second & plunge pool & 602 & second & plunge pool & 2051 \\
\hline second & $\lg r$ & 614 & second & igr & 2088 \\
\hline second & glide & 672 & second & riffle/run & 2106 \\
\hline second & bluff pool & 682 & second & glide & 2110 \\
\hline second & $\lg r$ & 710 & second & riffle/run & 2140 \\
\hline second & riffle/run & 730 & second & plunge pool & 2155 \\
\hline second & $\lg r$ & 837 & second & $\lg r$ & 2164 \\
\hline second & bluff pool & 880 & second & glide & 2179 \\
\hline second & glide & 902 & second & plunge pool & 2191 \\
\hline second & $\lg r$ & 938 & second & igr* & $2216^{*}$ \\
\hline second & plunge pool & 958 & second & glide* & $2222 *$ \\
\hline second & plunge pool* & $970 *$ & second & igr* & $2237^{*}$ \\
\hline second & $\lg r^{*}$ & $1000 *$ & second & cascade & 2237 \\
\hline second & $\lg r$ & 1006 & second $^{\mathrm{S} 4}$ & plunge pool & 2250 \\
\hline second & bluff pool & 1014 & second & riffle/run & 2280 \\
\hline second & $\lg r$ & 1120 & second & plunge pool & 2288 \\
\hline second & bluff pool & 1155 & second & glide & 2301 \\
\hline second & $\lg r$ & 1385 & second & igr & 2314 \\
\hline second & plunge pool & 1392 & second & plunge pool & 2341 \\
\hline second & riffle/run & 1440 & second & riffle/run & 2358 \\
\hline second & glide & 1480 & second & $\operatorname{lgr}$ & 2375 \\
\hline second & $\operatorname{lgr}$ & 1510 & second & riffle/run & 2401 \\
\hline second $^{\mathrm{S} 2}$ & plunge pool & 1530 & second & plunge pool & 2408 \\
\hline second & riffle/run & 1551 & second & $\lg$ & 2419 \\
\hline second & plunge pool & 1555 & second & plunge pool & 2426 \\
\hline second & riffle/run & 1578 & second & $\lg r$ & 2450 \\
\hline second & glide & 1598 & second & plunge pool & 2463 \\
\hline second & $\operatorname{lgr}$ & 1609 & second & igr & 2480 \\
\hline second & bluff pool & 1626 & second & riffle/run & 2497 \\
\hline
\end{tabular}




\begin{tabular}{|c|c|c|c|c|c|}
\hline stream & channel unit & endpoint (m) & stream & channel unit & endpoint (m) \\
\hline second & glide & 2507 & second & plunge pool* & $3640 *$ \\
\hline second & igr & 2514 & second & cascade & 3643 \\
\hline second & plunge pool & 2529 & second & igr* & 3643 \\
\hline second & riffle/run & 2541 & second & plunge pool & 3653 \\
\hline second & $\lg r$ & 2557 & second & $\lg r$ & 3663 \\
\hline second & glide & 2574 & second & plunge pool & 3670 \\
\hline second & plunge pool & 2580 & second & riffle/run & 3686 \\
\hline second & $\lg r$ & 2672 & second & plunge pool & 3697 \\
\hline second & riffle/run & 2702 & second & igr & 3703 \\
\hline second & igr & 2725 & second & plunge pool & 3712 \\
\hline second $^{\mathrm{S} 5}$ & plunge pool & 2745 & second & $\lg r$ & 3737 \\
\hline second & riffle/run & 2795 & second & glide & 3765 \\
\hline second & plunge pool & 2802 & second & igr & 3779 \\
\hline second & $\lg r$ & 2846 & second & plunge pool & 3784 \\
\hline second & igr & 2900 & second & $\lg r$ & 3818 \\
\hline second & $\lg r$ & 2932 & second & glide & 3836 \\
\hline second & igr & 3079 & second & plunge pool & 3840 \\
\hline second & plunge pool & 3092 & second & igr & 3852 \\
\hline second & igr & 3106 & second & plunge pool & 3861 \\
\hline second & plunge pool & 3120 & second & igr & 3869 \\
\hline second & igr & 3140 & second & cascade* & $3880 *$ \\
\hline second & glide & 3147 & second & plunge pool* & $3884 *$ \\
\hline second & igr & 3175 & second & igr* & $3894 *$ \\
\hline second & plunge pool & 3190 & second & plunge pool* & $3904^{*}$ \\
\hline second $^{\mathrm{S} 7}$ & $\operatorname{lgr}$ & 3243 & second & cascade* & $3927 *$ \\
\hline second & glide & 3258 & second & igr* & $3940 *$ \\
\hline second & $\operatorname{lgr}$ & 3288 & second & plunge pool* & $3945^{*}$ \\
\hline second & glide & 3302 & second & cascade & 3945 \\
\hline second & $\lg r$ & 3314 & second & riffle/run & 3992 \\
\hline second & bluff pool* & $3323^{*}$ & second $^{\mathrm{S} 11}$ & plunge pool & 4007 \\
\hline second & igr & $3332 *$ & second & riffle/run & 4022 \\
\hline second & riffle/run & 3375 & second & plunge pool & 4031 \\
\hline second & cascade & 3390 & second & riffle/run & 4046 \\
\hline second & riffle/run & 3401 & second & plunge pool & 4059 \\
\hline second & plunge pool & 3405 & second & glide & 4074 \\
\hline second & igr & 3419 & second & riffle/run & 4081 \\
\hline second & riffle/run & 3430 & second & plunge pool & 4093 \\
\hline second & igr & 3452 & second & riffle/run & 4101 \\
\hline second & cascade & 3482 & second & cascade & 4115 \\
\hline second & plunge pool & 3495 & second & glide & 4129 \\
\hline second & igr & 3544 & second & igr & 4149 \\
\hline second & cascade & 3612 & second & plunge pool & 4154 \\
\hline second & $\operatorname{lgr} *$ & $3626^{*}$ & second & glide & 4178 \\
\hline
\end{tabular}




\begin{tabular}{|c|c|c|c|c|c|}
\hline stream & channel unit & endpoint (m) & stream & channel unit & endpoint (m) \\
\hline second & igr & 4194 & odey & igr & 125 \\
\hline second & glide & 4202 & odey & plunge pool & 136 \\
\hline second & $\lg r$ & 4224 & odey & $\lg r$ & 168 \\
\hline second & riffle/run & 4250 & odey & plunge pool & 177 \\
\hline shaft & $\lg r$ & 13 & odey & igr & 195 \\
\hline shaft & glide & 20 & odey & plunge pool & 212 \\
\hline shaft & $\lg r$ & 30 & odey & cascade & 252 \\
\hline shaft & glide & 40 & odey & igr & 268 \\
\hline shaft & $\lg r$ & 45 & odey & cascade & 320 \\
\hline shaft & plunge pool & 51 & odey & igr & 338 \\
\hline shaft & $\lg r$ & 56 & odey & cacscade & 370 \\
\hline shaft & plunge pool & 62 & odey & igr & 376 \\
\hline shaft & glide & 70 & odey & glide & 384 \\
\hline shaft & plunge pool & 76 & odey & igr & 400 \\
\hline shaft & $\lg r *$ & $81 *$ & odey & plunge pool & 405 \\
\hline shaft & plunge pool* & $87 *$ & odey & cascade & 420 \\
\hline shaft & $\lg r^{*}$ & $90 *$ & odey & plunge pool & 430 \\
\hline shaft & plunge pool* & $101 *$ & odey & beaver pool & 476 \\
\hline shaft & glide* & $112^{*}$ & odey $^{\text {S9 }}$ & $\lg$ & 479 \\
\hline shaft & $\operatorname{lgr} *$ & $117^{*}$ & odey & glide & 489 \\
\hline shaft & $\lg r$ & 117 & odey & $\lg r$ & 503 \\
\hline shaft & glide & 125 & odey & plunge pool & 508 \\
\hline shaft & $\operatorname{lgr}$ & 128 & odey & $\lg r$ & 513 \\
\hline shaft & glide & 143 & odey & plunge pool & 518 \\
\hline shaft & $\lg r$ & 169 & odey & riflle/run & 527 \\
\hline shaft & plunge pool & 173 & odey & glide & 535 \\
\hline shaft $^{\text {s6 }}$ & $\lg r$ & 201 & odey & $\lg r$ & 541 \\
\hline shaft & cascade & 232 & odey & plunge pool & 552 \\
\hline shaft & igr & 261 & odey & $\lg r$ & 555 \\
\hline shaft & plunge pool & 266 & odey & plunge pool & 565 \\
\hline shaft & igr & 285 & odey & glide & 570 \\
\hline shaft & cascade & 326 & odey & $\lg r$ & 575 \\
\hline shaft & plunge pool & 331 & odey & plunge pool & 580 \\
\hline shaft & igr & 350 & odey & glide & 600 \\
\hline shaft & cascade & 400 & odey & $\lg r$ & 603 \\
\hline odey & igr & 20 & odey & plunge pool & 606 \\
\hline odey $^{\text {S8 }}$ & plunge pool & 24 & odey & $\lg r$ & 611 \\
\hline odey & igr & 27 & odey & glide & 620 \\
\hline odey & bluff pool & 31 & odey & $\lg r$ & 630 \\
\hline odey & $\lg r$ & 68 & odey & plunge pool & 635 \\
\hline odey & glide & 76 & odey & glide & 642 \\
\hline odey & igr & 88 & odey & $\lg r$ & 647 \\
\hline odey & plunge pool & 102 & odey & plunge pool & 651 \\
\hline
\end{tabular}




\begin{tabular}{|c|c|c|c|c|c|}
\hline stream & channel unit & endpoint (m) & stream & channel unit & endpoint (m) \\
\hline odey & lgr & 656 & 1.odey ${ }^{S 10}$ & glide & 464 \\
\hline odey & plunge pool & 660 & l.odey & $\operatorname{lgr}$ & 472 \\
\hline 1.odey & $\operatorname{lgr} *$ & $23^{*}$ & 1.odey & glide & 480 \\
\hline 1.odey & cascade* & $51^{*}$ & 1.odey & $\operatorname{lgr}$ & 489 \\
\hline 1.odey & $\lg r$ & 51 & 1.odey & plunge pool & 492 \\
\hline 1.odey & cacscade & 72 & 1.odey & cascade* & $512 *$ \\
\hline 1.odey & plunge pool & 77 & 1.odey & glide & 520 \\
\hline 1.odey & igr & 90 & 1.odey & $\operatorname{lgr}$ & 525 \\
\hline 1.odey & plunge pool & 92 & 1.odey & glide & 535 \\
\hline 1.odey & $\lg$ & 103 & 1.odey & $\operatorname{lgr}$ & 543 \\
\hline 1.odey & plunge pool & 110 & 1.odey & plunge pool & 547 \\
\hline 1.odey & $\operatorname{lgr}$ & 120 & 1.odey & $\operatorname{lgr}$ & 577 \\
\hline 1.odey & cascade & 137 & 1.odey & plunge pool & 581 \\
\hline 1.odey & $\operatorname{lgr}$ & 149 & 1.odey & igr & 588 \\
\hline 1.odey & plunge pool & 152 & 1.odey & plunge pool & 590 \\
\hline 1.odey & $\operatorname{lgr}$ & 158 & 1.odey & $\lg r$ & 597 \\
\hline 1.odey & glide & 166 & 1.odey & plunge pool & 600 \\
\hline 1.odey & $\operatorname{lgr}$ & 189 & & & \\
\hline 1.odey & glide & 192 & & & \\
\hline 1.odey & lgr & 200 & & & \\
\hline 1.odey & cascade & 221 & & & \\
\hline 1.odey & $\operatorname{lgr}$ & 232 & & & \\
\hline 1.odey & plunge pool & 238 & & & \\
\hline 1.odey & $\operatorname{lgr}$ & 244 & & & \\
\hline 1.odey & plunge pool & 249 & & & \\
\hline 1.odey & glide & 262 & & & \\
\hline 1.odey & $\operatorname{lgr}$ & 264 & & & \\
\hline 1.odey & glide & 271 & & & \\
\hline 1.odey & cascade & 295 & & & \\
\hline 1.odey & glide & 305 & & & \\
\hline 1.odey & igr & 315 & & & \\
\hline 1.odey & glide & 328 & & & \\
\hline 1.odey & $\operatorname{lgr}$ & 333 & & & \\
\hline 1.odey & glide & 337 & & & \\
\hline 1.odey & $\operatorname{lgr}$ & 351 & & & \\
\hline 1.odey & riffle/run & 373 & & & \\
\hline 1.odey & igr & 385 & & & \\
\hline 1.odey & plunge pool & 393 & & & \\
\hline 1.odey & glide & 398 & & & \\
\hline 1.odey & plunge pool & 402 & & & \\
\hline 1.odey & igr & 425 & & & \\
\hline 1.odey & cascade & 433 & & & \\
\hline 1.odey & igr & 451 & & & \\
\hline
\end{tabular}


Table A11. Stream microhabitat parameters for the Second Fork watershed. Parameters were visually estimated along transects spaced 50 meters apart. The survey began at the mouth of Second Fork and proceeded upstream throughout the watershed. S\# denotes the beginning of a fish sampling site (Figure 3.). $\mathrm{CW}=$ channel width $\mathrm{WW}=$ wetted width.

\begin{tabular}{|c|c|c|c|c|c|c|c|c|c|c|}
\hline Stream & $\begin{array}{r}\mathrm{CW} \\
(\mathrm{m})\end{array}$ & $\begin{array}{l}\text { WW } \\
(\mathrm{m})\end{array}$ & $\begin{array}{c}\text { canopy } \\
(\%)\end{array}$ & $\begin{array}{l}\text { max. depth } \\
(\mathrm{cm})\end{array}$ & $\begin{array}{l}\text { avg.depth } \\
(\mathrm{cm})\end{array}$ & $\begin{array}{c}\text { total cover } \\
(\%)\end{array}$ & $\begin{array}{l}\text { instream } \\
\text { cover(\%) }\end{array}$ & $\begin{array}{l}\text { bank } \\
\text { cover(\%) }\end{array}$ & $\begin{array}{c}\underset{(\%)}{\operatorname{margin}} \\
\end{array}$ & $\begin{array}{c}\text { spawning } \\
(\%)\end{array}$ \\
\hline second & 8 & 8 & 30 & 35 & 25 & 10 & 2 & 8 & 15 & 15 \\
\hline second & 8 & 8 & 40 & 40 & 25 & 15 & 7 & 8 & 10 & 10 \\
\hline second & 8 & 6 & 60 & 75 & 35 & 75 & 70 & 5 & 5 & 5 \\
\hline second & 8 & 5 & 50 & 55 & 20 & 60 & 50 & 10 & 10 & 0 \\
\hline second & 9 & 6 & 50 & 55 & 20 & 40 & 30 & 10 & 10 & 5 \\
\hline second $^{\mathrm{S} 1}$ & 11 & 9 & 75 & 40 & 20 & 25 & 10 & 15 & 25 & 5 \\
\hline second & 10 & 6 & 50 & 75 & 40 & 55 & 45 & 10 & 2 & 2 \\
\hline second & 14 & 4 & 10 & 60 & 30 & 15 & 5 & 10 & 15 & 5 \\
\hline second & 12 & 5 & 10 & 70 & 35 & 10 & 4 & 6 & 15 & 5 \\
\hline second & 9 & 4 & 10 & 35 & 25 & 20 & 15 & 5 & 10 & 10 \\
\hline second & 8 & 5 & 25 & 55 & 30 & 30 & 20 & 10 & 25 & 10 \\
\hline second & 7 & 5 & 70 & 120 & 50 & 55 & 45 & 10 & 10 & 5 \\
\hline second & 10 & 7 & 50 & 80 & 65 & 20 & 5 & 15 & 25 & 0 \\
\hline second & 10 & 7 & 45 & 180 & 70 & 40 & 35 & 5 & 5 & 0 \\
\hline second & 9 & 3 & 40 & 110 & 60 & 35 & 28 & 7 & 5 & 3 \\
\hline second & 10 & 8 & 45 & 35 & 20 & 20 & 15 & 5 & 15 & 5 \\
\hline second & 11 & 7 & 40 & 60 & 25 & 30 & 15 & 15 & 15 & 0 \\
\hline second & 12 & 6 & 40 & 160 & 80 & 35 & 30 & 5 & 10 & 10 \\
\hline second & 10 & 5 & 35 & 45 & 30 & 50 & 25 & 25 & 15 & 10 \\
\hline second & 30 & 6 & 30 & 140 & 60 & 65 & 50 & 15 & 10 & 15 \\
\hline second & 10 & 4 & 35 & 120 & 60 & 30 & 25 & 5 & 8 & 2 \\
\hline second & 15 & 6 & 35 & 75 & 40 & 30 & 25 & 5 & 20 & 10 \\
\hline second & 10 & 4 & 45 & 75 & 35 & 35 & 20 & 15 & 5 & 10 \\
\hline second & 11 & 8 & 60 & 45 & 20 & 60 & 55 & 5 & 40 & 2 \\
\hline second & 10 & 9 & 65 & 35 & 25 & 65 & 55 & 10 & 30 & 10 \\
\hline second & 10 & 9 & 70 & 35 & 25 & 55 & 50 & 5 & 35 & 5 \\
\hline second & 10 & 7 & 60 & 90 & 40 & 60 & 55 & 5 & 35 & 5 \\
\hline second & 10 & 8 & 60 & 60 & 40 & 55 & 50 & 5 & 35 & 2 \\
\hline second & 9 & 8 & 50 & 25 & 15 & 60 & 50 & 10 & 30 & 10 \\
\hline second & 8 & 8 & 20 & 65 & 35 & 50 & 40 & 10 & 20 & 15 \\
\hline second $^{\mathrm{S} 2}$ & 11 & 7 & 25 & 55 & 30 & 55 & 45 & 10 & 25 & 15 \\
\hline second & 7 & 6 & 70 & 65 & 35 & 55 & 50 & 5 & 20 & 15 \\
\hline second & 9 & 6 & 65 & 50 & 35 & 60 & 50 & 10 & 20 & 10 \\
\hline second & 9 & 7 & 60 & 60 & 30 & 50 & 40 & 10 & 25 & 15 \\
\hline second $^{\text {S3 }}$ & 9 & 6 & 60 & 65 & 35 & 65 & 60 & 5 & 10 & 10 \\
\hline second & 9 & 5 & 45 & 110 & 45 & 80 & 70 & 10 & 10 & 20 \\
\hline second & 8 & 6 & 50 & 120 & 50 & 70 & 60 & 10 & 25 & 20 \\
\hline second & 8 & 5 & 45 & 140 & 45 & 55 & 50 & 5 & 25 & 15 \\
\hline second & 16 & 14 & 30 & 110 & 45 & 60 & 50 & 10 & 20 & 20 \\
\hline second & 8 & 7 & 35 & 110 & 40 & 45 & 40 & 5 & 35 & 15 \\
\hline second & 9 & 8 & 40 & 60 & 30 & 45 & 35 & 10 & 40 & 25 \\
\hline second & 8 & 7 & 40 & 70 & 45 & 45 & 30 & 15 & 25 & 20 \\
\hline second & 8 & 7 & 40 & 55 & 30 & 45 & 30 & 15 & 30 & 20 \\
\hline second $^{\mathrm{S} 4}$ & 14 & 5 & 45 & 95 & 45 & 50 & 45 & 5 & 25 & 15 \\
\hline second & 9 & 6 & 45 & 80 & 40 & 45 & 35 & 10 & 20 & 15 \\
\hline second & 9 & 6 & 40 & 80 & 35 & 35 & 30 & 5 & 20 & 10 \\
\hline second & 9 & 6 & 35 & 110 & 50 & 50 & 40 & 10 & 25 & 20 \\
\hline
\end{tabular}


Stream CW WW canopy max. depth avg.depth total cover instream bank margin spawning
(m) (m) (\%)
(cm) (cm)
$(\%)$
cover $(\%) \quad$ cover $(\%) \quad(\%)$
(\%)

\begin{tabular}{|c|c|c|c|c|c|c|c|c|c|c|}
\hline second & 9 & 6 & 30 & 75 & $3 \mid 5$ & 60 & 50 & 10 & 25 & 20 \\
\hline second & 10 & 6 & 30 & 75 & 35 & 50 & 35 & 15 & 35 & 25 \\
\hline second & 9 & 5 & 45 & 140 & 60 & 75 & 60 & 15 & 15 & 15 \\
\hline second & 9 & 5 & 45 & 65 & 35 & 45 & 30 & 15 & 45 & 20 \\
\hline second & 9 & 5 & 45 & 20 & 15 & 35 & 25 & 10 & 50 & 25 \\
\hline second & 9 & 5 & 45 & 45 & 25 & 45 & 35 & 10 & 40 & 15 \\
\hline second & 10 & 6 & 50 & 65 & 30 & 50 & 30 & 20 & 15 & 15 \\
\hline second $^{\text {S5 }}$ & 7 & 5 & 65 & 70 & 40 & 55 & 53 & 2 & 20 & 10 \\
\hline second & 7 & 5 & 60 & 55 & 35 & 50 & 50 & 0 & 20 & 10 \\
\hline second & 10 & 5 & 40 & 65 & 35 & 65 & 55 & 10 & 20 & 20 \\
\hline second & 9 & 5 & 50 & 65 & 30 & 50 & 48 & 2 & 45 & 15 \\
\hline second & 9 & 6 & 40 & 60 & 30 & 55 & 45 & 10 & 40 & 15 \\
\hline second & 8 & 6 & 65 & 85 & 45 & 55 & 50 & 5 & 30 & 10 \\
\hline second & 9 & 6 & 55 & 65 & 30 & 45 & 35 & 10 & 10 & 25 \\
\hline second & 8 & 6 & 50 & 55 & 35 & 40 & 35 & 5 & 20 & 25 \\
\hline second $^{\mathrm{S} 7}$ & 7 & 5 & 80 & 30 & 20 & 50 & 50 & 0 & 40 & 20 \\
\hline second & 8 & 5 & 75 & 25 & 20 & 55 & 55 & 0 & 45 & 15 \\
\hline second & 18 & 6 & 50 & 65 & 35 & 60 & 45 & 15 & 40 & 10 \\
\hline second & 9 & 5 & 55 & 55 & 35 & 50 & 40 & 10 & 30 & 10 \\
\hline second & 9 & 5 & 65 & 45 & 30 & 55 & 45 & 10 & 20 & 5 \\
\hline second & 8 & 5 & 55 & 85 & 40 & 65 & 55 & 10 & 20 & 10 \\
\hline second & 7 & 5 & 50 & 60 & 35 & 60 & 55 & 5 & 20 & 10 \\
\hline second & 8 & 5 & 45 & 80 & 45 & 55 & 50 & 5 & 25 & 20 \\
\hline second & 10 & 5 & 60 & 75 & 35 & 55 & 50 & 5 & 30 & 15 \\
\hline second & 8 & 4 & 60 & 75 & 40 & 50 & 40 & 10 & 25 & 15 \\
\hline second & 10 & 4 & 55 & 160 & 50 & 50 & 40 & 10 & 20 & 15 \\
\hline second & 9 & 4 & 55 & 45 & 30 & 40 & 30 & 10 & 20 & 15 \\
\hline second & 10 & 4 & 55 & 60 & 35 & 50 & 45 & 5 & 15 & 15 \\
\hline second & 10 & 5 & 45 & 140 & 55 & 60 & 50 & 10 & 15 & 20 \\
\hline second & 14 & 5 & 45 & 120 & 60 & 65 & 55 & 10 & 15 & 15 \\
\hline second $^{\mathrm{S} 11}$ & 8 & 5 & 40 & 75 & 40 & 60 & 45 & 15 & 15 & 20 \\
\hline second & 9 & 6 & 45 & 90 & 40 & 50 & 40 & 10 & 25 & 25 \\
\hline second & 8 & 6 & 45 & 85 & 35 & 45 & 35 & 10 & 20 & 15 \\
\hline second & 8 & 6 & 55 & 65 & 30 & 45 & 35 & 10 & 25 & 15 \\
\hline second & 7 & 4 & 75 & 55 & 25 & 45 & 30 & 15 & 25 & 20 \\
\hline second & 6 & 5 & 70 & 30 & 20 & 50 & 40 & 10 & 25 & 10 \\
\hline shaft & 3 & 2 & 70 & 40 & 20 & 65 & 35 & 30 & 20 & 35 \\
\hline shaft & 8 & 3 & 55 & 70 & 25 & 55 & 30 & 25 & 20 & 45 \\
\hline shaft & 6 & 3 & 70 & 35 & 15 & 45 & 10 & 35 & 25 & 50 \\
\hline shaft & 4 & 3 & 80 & 25 & 20 & 45 & 25 & 20 & 20 & 20 \\
\hline shaft $^{\mathrm{s} 6}$ & 4 & 3 & 85 & 35 & 20 & 25 & 5 & 20 & 15 & 10 \\
\hline shaft & 5 & 3 & 85 & 60 & 20 & 55 & 30 & 25 & 25 & 20 \\
\hline shaft & 6 & 4 & 80 & 75 & 30 & 60 & 55 & 5 & 15 & 25 \\
\hline shaft & 5 & 3 & 85 & 80 & 35 & 65 & 60 & 5 & 25 & 25 \\
\hline odey $^{\text {S8 }}$ & 4 & 4 & 70 & 60 & 30 & 45 & 40 & 5 & 15 & 15 \\
\hline odey & 6 & 4 & 60 & 35 & 30 & 45 & 40 & 5 & 15 & 20 \\
\hline odey & 5 & 4 & 65 & 85 & 40 & 50 & 40 & 10 & 10 & 15 \\
\hline odey & 6 & 3 & 70 & 60 & 35 & 55 & 50 & 5 & 10 & 15 \\
\hline odey & 7 & 5 & 75 & 100 & 65 & 75 & 75 & 0 & 5 & 5 \\
\hline odey & 7 & 5 & 85 & 120 & 70 & 80 & 80 & 0 & 10 & 10 \\
\hline odey & 6 & 5 & 80 & 140 & 75 & 80 & 75 & 5 & 5 & 3 \\
\hline odey & 4 & 3.5 & 75 & 40 & 20 & 60 & 50 & 10 & 20 & 15 \\
\hline
\end{tabular}


Stream CW WW canopy max. depth avg.depth total cover instream bank margin spawning
(m) $\quad(\mathrm{m}) \quad(\%)$
$(\mathrm{cm})$
$(\mathrm{cm})$
$(\%)$
cover $(\%) \quad \operatorname{cover}(\%) \quad(\%)$
$(\%)$

\begin{tabular}{|c|c|c|c|c|c|c|c|c|c|c|}
\hline odey & 7 & 5 & 65 & 140 & 60 & 45 & 10 & 35 & 20 & 5 \\
\hline odey $^{S 9}$ & 3.5 & 2 & 85 & 60 & 25 & 40 & 30 & 10 & 20 & 20 \\
\hline odey & 4 & 2.5 & 90 & 75 & 30 & 45 & 30 & 15 & 20 & 20 \\
\hline odey & 3 & 2.5 & 75 & 40 & 20 & 50 & 35 & 15 & 15 & 25 \\
\hline odey & 2.5 & 2.5 & 85 & 50 & 25 & 45 & 35 & 10 & 15 & 25 \\
\hline 1.odey & 7 & 3 & 60 & 45 & 20 & 65 & 55 & 10 & 10 & 5 \\
\hline 1.odey & 4 & 3 & 60 & 35 & 25 & 65 & 55 & 10 & 15 & 20 \\
\hline 1.odey & 3 & 2 & 55 & 35 & 20 & 55 & 40 & 15 & 15 & 20 \\
\hline 1.odey & 4 & 2 & 50 & 15 & 10 & 60 & 55 & 5 & 15 & 20 \\
\hline 1.odey & 4 & 3 & 50 & 65 & 15 & 55 & 40 & 15 & 20 & 25 \\
\hline 1.odey & 4 & 3.5 & 45 & 50 & 15 & 50 & 35 & 15 & 25 & 20 \\
\hline l.odey & 3.5 & 3 & 55 & 60 & 25 & 55 & 40 & 15 & 25 & 25 \\
\hline 1.odey & 3.5 & 2.5 & 50 & 60 & 20 & 60 & 45 & 15 & 20 & 15 \\
\hline 1.odey & 4 & 3 & 55 & 30 & 15 & 55 & 50 & 5 & 15 & 5 \\
\hline 1.odey ${ }^{\mathrm{S} 10}$ & 3.5 & 3 & 15 & 45 & 30 & 50 & 20 & 30 & 45 & 50 \\
\hline 1.odey & 7 & 3 & 15 & 55 & 20 & 50 & 25 & 25 & 35 & 40 \\
\hline 1.odey & 2.5 & 1.5 & 20 & 45 & 15 & 40 & 30 & 10 & 30 & 55 \\
\hline
\end{tabular}




\section{Peter J. Lamothe}

913 Snider St.

Morgantown, WV 26505

(304) 296-7557

e-mail:p_lamothe@yahoo.com

\section{$\underline{\text { Education }}$}

- Graduate Student, Wildlife \& Fisheries Resources, WVU

2000-2002

- B.A. Zoology, University of Maine

1999

- A.A.S. Marine Engineering, Southern Maine Technical College

1991

\section{Employment History}

West Virginia Cooperative Fish \& Wildlife Research Unit, West Virginia University, Morgantown, WV - Graduate Research Assistant - Restoring a coldwater fishery to the Upper Shavers Fork Watershed

Maine Cooperative Fish \& Wildlife Research Unit, University 1999 of Maine, Orono, ME - Field Research Assistant - Association between fall emigration and spawning activity in lake populations of brook trout (Salvelinus fontinalis) in Acadia National Park, Maine

Maine Cooperative Fish \& Wildlife Research Unit, University 1998 of Maine, Orono, ME - Field Research Assistant - Habitat selection of yellow-phase American Eel (Anguilla rostrata)

USGS Biological Resources Division - Leetown Science Center 1997 Field Station - University of Maine, Orono, ME - Field Research Assistant and Laboratory Assistant

\section{Independent Research Projects}

West Virginia Cooperative Fish \& Wildlife Research Unit, 2000-2002 West Virginia University, Morgantown, WV - Spatial population dynamics of brook trout (Salvelinus fontinalis) in the upper Shavers Fork watershed - Master's thesis research project

Maine Cooperative Fish \& Wildlife Research Unit, University of Maine, Orono, ME - Homing and movement of yellow-phase American eels in freshwater ponds - Undergraduate independent research project 


\section{$\underline{\text { Publications and Presentations }}$}

Lamothe, P.J., M. Gallagher, D.P. Chivers \& J.R. Moring. 2000. Homing and movement of yellow-phase American eels in freshwater ponds.

Environmental Biology of Fishes 58:393-399.

Petty, J.T., J. Freund, P.J. Lamothe \& P.M. Mazik. 2001. Quantifying the microhabitat characteristics of hydraulic channel units in the upper Shavers Fork basin. Proceedings of the Annual Conference of the Southeastern Association of Fish and Wildlife Agencies IN PRESS

Lamothe, P.J., P.M. Mazik, \& J.T. Petty. 2001. Habitat complementation and the spatial population dynamics of brook trout in a central Appalachian watershed. $81^{\text {st }}$ annual meeting of the American Society of Ichthyologists \& Herpetologists

Lamothe, P.J., J.T. Petty, \& P. Mazik. 2001. Spatial population dynamics of brook Trout (Salvelinus fontinalis) in the Upper Shavers Fork Watershed. $47^{\text {th }}$ Annual Tri-State Fisheries Conference

Petty, J.T., P.J. Lamothe, J. Hansbarger, \& J. Freund. 2001. Quantifying spatial variation in trout habitat suitability at a watershed scale. $47^{\text {th }}$ Annual Tri-State Fisheries Conference

Lamothe, P.J., J.T. Petty, \& P. Mazik. 2001. Restoring a coldwater fishery to the Upper Shavers Fork, West Virginia - Parkersburg WV Chapter of Trout Unlimited Annual Meeting

Lamothe, P.J., J. Bopp, J. Hansbarger, R. Gaujot, P. Mazik, T. Petty. 2000.

Restoring a coldwater fishery to the Upper Shavers Fork, West Virginia - a poster presentation $-12^{\text {th }}$ International Trout Stream Habitat Improvement Workshop

Lamothe P.J., J.T. Petty \& P.M. Mazik. Spatial population dynamics of brook trout (Salvelinus fontinalis) in the upper Shavers Fork watershed a thesis proposal - West Virginia Cooperative Fish and Wildlife Research Unit 1999 Annual Meeting

\section{$\underline{\text { Awards/Certificates }}$}

- Penn State - Field techniques for small watershed assessment

- University of Maine Presidential Academic Achievement Award

- Department of the Interior Motorboat Operators Certification

- Undergraduate Independent Research Award 